ENCUESTA 



\section{ENCUESTA SOBRE LA IGUALDAD ENTRE HOMBRES Y MUJERES}

\section{PRESENTACIÓN}

El objetivo del Consejo de Redacción de esta revista ha sido siempre el de intentar abordar los temas de actualidad, por complejos o delicados que fuesen, y llamar la atención sobre los problemas jurídico-constitucionales que en cada momento resultaban de mayor gravedad. En materia de igualdad entre hombres y mujeres, el debate público, así como el interés y la discusión científica, han ido progresivamente in crescendo desde la aprobación de la Constitución de 1978 hasta alcanzar hoy en día un punto culminante, en el que creemos necesario invitar a los estudiosos constitucionalistas a reflexionar sobre este tema tan central.

Es cierto que la Constitución consagra la igualdad entre hombres y mujeres, estableciendo la prohibición de discriminación por razón de sexo, en su art. 14, y encargando a los poderes públicos la tarea de promover las condiciones para que la igualdad sea real y efectiva, y la de remover los obstáculos que impidan o dificulten su plenitud, según la conocida fórmula del art. 9.2. Y es cierto que, con ello, rompe con el orden jurídico inmediatamente anterior, en el que, hasta las reformas que se acometieron en la última parte del régimen franquista, la mujer había estado socialmente relegada a un papel secundario y jurídicamente situada en una posición subordinada a la del hombre y sin posibilidad de desenvolverse con autonomía y libertad. Así, nuestra Constitución, con el reconocimiento de la dignidad humana como fundamento del orden político y de la igualdad, en los términos ya señalados, nos situó en la órbita del constitucionalismo del Estado social y democrático de derecho que caracteriza a los Estados europeos, excluyendo tratamientos diferentes injustificados que no respeten el principio de la igualdad formal y fijando como objetivo a perseguir el de la igualdad real y efectiva en el reconocimiento y disfrute de los derechos por parte de las mujeres.

El problema es que estos dos objetivos, sin embargo, no son fáciles de alcanzar. Dejando a un lado las dificultades técnico-jurídicas que plantea el principio de la igualdad formal, y baste recordar en este sentido la compleja construcción jurisprudencial del juicio de igualdad, la verdadera dificultad es la que trae consigo el principio de la igualdad material, que obliga a los poderes públicos a analizar la realidad y a intervenir en ella, de forma activa, tomando todas las medidas 
que sean necesarias para avanzar en la consecución de la igualdad real y efectiva: políticas públicas, medidas legislativas, planes de actuación... Y esta es una tarea realmente ambiciosa, porque se trata de superar una situación de desigualdad estructural, de hondísimas raíces históricas y culturales, que desde luego no queda revertida únicamente con la proclamación constitucional del reconocimiento de la igualdad. Para avanzar en la consecución de este cometido son necesarias medidas de muy diferente tipo y relativas a muy distintos ámbitos también (el educativo, el de la comunicación, el laboral, el de la representación política...), y tampoco parece sencillo, según muestran el debate político y el jurídico, tener la seguridad de que las medidas adoptadas sean las adecuadas para alcanzar el fin perseguido.

Por todo ello, cuatro décadas después de aprobarse la Constitución se puede decir que aún queda mucho por hacer. Esta es la razón por la que la reivindicación de la igualdad para las mujeres moviliza a una parte muy considerable de la población, como muestran, por ejemplo, las manifestaciones que tienen lugar en los últimos años con motivo del día de la mujer el 8 de marzo, y por la que se han realizado muchas propuestas sobre la conveniencia de reformar la Constitución desde el punto de vista de la igualdad de hombres y mujeres.

Así pues, abrimos el presente número con una encuesta en la que especialistas en la materia se pronuncian sobre una serie de cuestiones que les hemos planteado en relación a este tema y que, como siempre, son la excusa para que puedan ofrecernos con toda libertad sus opiniones al respecto y para animar a los lectores a reflexionar sobre este principio tan esencial para nuestro orden político.

\section{CUESTIONES}

1. La igualdad de la mujer se reconoce por primera vez en nuestro país en la Constitución de 1931. ¿Qué reflexiones puede hacernos de aquel precedente bistórico? ¿Y de la situación en que se encuentra la igualdad entre hombres y mujeres en 1977?

2. ¿Cómo valora la forma en que la Constitución de 1978 recoge la igualdad entre mujeres y hombres? ¿En qué medida puede ser el reflejo del número de mujeres constituyentes? ¿Cómo explica que este tema apenas ocupase espacio en los debates constituyentes?

3. ¿Cuáles cree que han sido los avances más reseñables en los últimos cuarenta años? ¿Cuáles considera que han sido los obstáculos más importantes y los objetivos no alcanzados?

4. Se han realizado muchas propuestas sobre la conveniencia de reformar la Constitución desde el punto de vista de la igualdad de hombres y mujeres ¿Qué opinión tiene al respecto?

5. ¿Cree que sin el respaldo del derecho internacional se hubiera avanzado como se ha becho en materia de igualdad? Además de este ¿Cuáles han sido a su juicio los impulsos jurídicos o politicos que han determinado los avances (y retrocesos) realizados? 
6. ¿Qué valoración le merece la interpretación que ha realizado el Tribunal Constitucional del principio de igualdad entre mujeres y hombres? ¿Considera que el juicio de igualdad, en este caso, tiene singularidades que lo diferencian de los otros «rasgos sospechosos» del art. 14?

7. Transcurridos ya unos años, ¿Cómo cabe valor la actividad del legislador en esta materia, especialmente a través de las leyes de igualdad y contra la violencia de género?

\section{ENCUESTADOS}

MARIA LUISA BALAGUER CALLEJÓN. Catedrática de Derecho Constitucional, Universidad de Málaga

PALOMA BIGLINO CAMPOS. Catedrática de Derecho Constitucional, Universidad de Valladolid

ÁNGELA FIGUERUELO BURRIEZA. Catedrática de Derecho Constitucional, Universidad de Salamanca

TERESA FREIXES SANJUAN. Catedrática de Derecho Constitucional, Universidad Autónoma de Barcelona

ITZIAR GÓMEZ FERNÁNDEZ. Profesora Titular de Derecho Constitucional, Universidad Carlos III

FERNANDO REY MARTÍNEZ. Catedrático de Derecho Constitucional, Universidad de Valladolid

OCTAVIO SALAZAR BENÍTEZ. Catedrático de Derecho Constitucional, Universidad de Córdoba

\section{RESPUESTAS}

1. La igualdad de la mujer se reconoce por primera vez en nuestro país en la Constitución de 1931. ¿Qué reflexiones puede hacernos de aquel precedente histórico? ¿Y de la situación en que se encuentra la igualdad entre hombres y mujeres en 1977?

\section{MARIA LUISA BALAGUER CALLEJÓN}

La regulación de la igualdad entre mujeres y hombres en la Constitución de 1931 , en lo que se refiere a su derecho al voto, tuvo como se sabe, un proceso complicado y se aprobó finalmente con un escaso margen de diferencia en las Cortes de la República. Y las mujeres de la II República mantuvieron respecto del momento en que debía aprobarse el sufragio para las mujeres, posiciones muy relativizadas por el momento histórico. La personalización en V. Kent y Clara Campoamor de dos posiciones diferentes respecto del sufragio, tenían más recorrido respecto de los criterios de adopción de ese derecho en ese momento 
concreto. Los Diarios de Sesiones de las Cortes registran con toda fidelidad lo que allí ocurrió, aunque se haya desdibujado por versiones, a menudo interesadas y mediatizadas por la recurrente y siempre atractiva escena de un conflicto entre dos mujeres respecto de sus derechos. La frase apodíctica de V. Kent en relación con su dilema personal, se interpreta interesadamente como una negativa a lo que constituye solamente una estrategia política dirigida a defender la República en aquellos momentos. La frase textual, «Es significativo... que yo me dirija a la Cámara para decir que el voto femenino debe aplazarse», no dejaba lugar a dudas acerca de la necesidad de aplazar, pero la contestación de Clara Campoamor es tajante y dura: «Lejos yo de censurar ni de atacar las manifestaciones de mi colega Kent; comprendo por el contrario, la tortura de su espíritu al haberse visto en trance de negar, como ha negado, la capacidad inicial de la mujer. Creo que por sus pensamientos ha debido de pasar de alguna forma la amarga frase de Anatole France cuando nos habla de aquellos socialistas que forzados por la necesidad, iban a Parlamento a legislar contra los suyos». Esta contradicción, es tan aparente como muchas otras aporías del feminismo; como las que parten de la idea de una contradicción insalvable entre feminismo y marxismo, o entre feminismo y forma de estado, pero si lo observamos ahora con perspectiva histórica, la República, al ser en ese momento una exigencia de la democracia en España, insustituible entonces por cualquier otra forma de gobierno, constituía una precondición que V. Kent veía con clarividencia. Las consecuencias presuntamente negativas del voto de las mujeres en las elecciones posteriores no se han podido demostrar, como tampoco lo contrario, pero lo que interesa resaltar aquí es la posición indiciaria del movimiento feminista en ese momento y la necesidad de atender a estrategias capaces de rentabilizar los logros del feminismo.

Es cierto que se reconoce el derecho al sufragio en la Constitución de la II República en 1931, pero esto es solamente un derecho político muy elemental, que no tendrá demasiada trascendencia en la vida cotidiana de las mujeres, y vendrá además acompañado de la culpabilidad colectiva a la mujer por considerar que tendría un efecto negativo para la República. Más interés podían tener en este sentido los derechos que afectaban a las mujeres en las leyes civiles, como la de divorcio, o en la que algunos territorios, como Cataluña, llegaron a tomar vigencia como la del aborto. Esta legislación fue fruto también como es sabido, de la lucha de mujeres como Carmen de Burgos, Pardo Bazán y otras, que en sus experiencias personales había sufrido las consecuencias de matrimonios malogrados, y pretendían regular estas situaciones que perjudicaban sobre todo a las mujeres.

\section{PALOMA BIGLINO CAMPOS}

La historia constitucional demuestra que no basta con las proclamaciones constitucionales para hacer efectivos los derechos ni para evitar que sean reversibles. Como es de sobra conocido, el art. 36 de la Constitución de la II República 
proclamaba, por primera vez en España, la igualdad de derechos electorales del hombre y de la mujer. Dicho precepto afirmaba que «los ciudadanos de uno y de otro sexo, mayores de veintitrés años, tendrán los mismos derechos electorales conforme determinen las leyes». Ahora bien, la elaboración de ese artículo ya dejaba presagiar la temporalidad de la medida y los difíciles tiempos que todavía esperaban a las mujeres.

La mayor parte de los argumentos que se utilizaron en el debate parlamentario fueron de oportunidad. Así, se discutió sobre la capacidad intelectual de la mujer, acerca del papel que le corresponde en la sociedad y, sobre todo, en torno a las opciones políticas por las que se inclinaría. Pocos fueron quienes tuvieron en cuenta la idea de igualdad y de dignidad de la persona. La más destacada, en esta línea, fue sin duda, la diputada del partido Radical Clara Campoamor. Esta, en su famoso discurso pronunciado el primero de octubre de $1931^{1}$, exigió que, a la hora de tomar una decisión, predominaran las consideraciones éticas, de principio, sobre el puro oportunismo político.

Tras el debate, que M. Azaña, de manera hiriente, calificó de «muy divertido, el precepto resultó aprobado por 161 votos contra 121 y un elevado número de ausencias en el hemiciclo. El Sol, uno de los principales diarios de la época, de corte intelectual y liberal, calificó la medida como «un gesto de galantería» en el que «los hijos de España se jugaron a cara y cruz un régimen por gusto de sus mujeres» ${ }^{2}$.

Antes señalaba que esta victoria de la igualdad no fue definitiva. No merece la pena analizar los derechos políticos de las mujeres durante el franquismo: si los varones tenían pocos, todavía menos correspondían a las mujeres, que sólo podían votar cuando eran cabezas de familia. Con el resto de los derechos la situación no era muy diferente. Baste, quizás, con subrayar que todavía en los años setenta sólo tenían estudios superiores el $0,4 \%$ de las mujeres y trabajaban 23 mujeres de cada 100, frente a una tasa de ocupación masculina de casi el $80 \%{ }^{3}$.

La regulación jurídica obedecía y, a la vez, reforzaba esta situación de desigualdad. Recordemos que, hasta 1975, el art. 23 del Código Civil disponía la pérdida de nacionalidad española para las mujeres que contrajeran matrimonio con un extranjero. Además, de un lado, la mujer debía obediencia al marido y estaba obligada a seguirle donde este fijara su residencia. De otro, el cónyuge varón tenía derecho a administrar los bienes de la esposa y la representaba legalmente. Para que esta pudiera comprar o vender, aunque fuera con su propio patrimonio, necesitaba licencia marital.

Cuando los datos son los que son, creo de está de más cualquier comentario.

1 Diario de Sesiones de las Cortes Constituyentes de la República Española, n. ${ }^{\circ} 48,1931$, pp. 1352-54.

2 https://www.almendron.com/artehistoria/historia-de-espana/edad-contemporanea/el-votofemenino-en-espana/la-mujer-en-la-republica-1931-1936/.

3 INE, La sociedad española tras 25 años de Constitución, 2003, http://www.ine.es/ss/Satellite?L=es_ES\&c $=$ INEPublicacion_C\&cid $=1259925266299 \& \mathrm{p}=1254735110672 \&$ pagename $=$ ProductosYServicios $\% 2$ FPYSLayout\&param1 = PYSDetalleGratuitas. 


\section{ÁNGELA FIGUERUELO BURRIEZA}

El concepto de ciudadanía que surge con el Estado Liberal a finales del siglo XVIII es un concepto excluyente porque, la idea de sujeto de derechos se construye sin tener en cuenta el sexo y obviando la construcción social del género. Las mujeres quedaron excluidas del concepto de sujetos de derechos porque la ruptura entre norma y realidad no se origina en el ámbito donde las mujeres quedaban recluidas: el ámbito doméstico. El pacto de la sociedad civil sólo se realizó entre varones iguales y libres y las mujeres únicamente participaban en el contrato sexual, presente en el previo estado de naturaleza.

Los movimientos revolucionarios de los siglos XIX y XX amplían paulatinamente el concepto de ciudadanía pero seguimos asistiendo a una democracia formal que no va más allá del pacto social inicial que sigue siendo homogéneo y permanece inalterado. Se amplió el elenco de sujetos de derechos al incluir a todos los varones, sin distinción de capacidad económica y de raza y se amplió el derecho de sufragio: en principio a todos los varones, en plenitud de derechos civiles y políticos, que hubieran cumplido cierta edad y paulatinamente a las mujeres a lo largo del siglo Xx. La mujer española consiguió el estatus de plena ciudadanía con la aprobación del artículo 36 de la Constitución de la II República en 1931. El evento tuvo lugar el día 1 de octubre del mismo año gracias al tesón y al empeño de una diputada feminista del Partido Radical: Clara Campoamor.

Aunque en el siglo xx encontramos en España casos aislados de mujeres emancipadas no se dio, en el primer tercio de dicho siglo, un incipiente movimiento feminista en nuestro país. Existieron algunas asociaciones de mujeres pero se ocupaban principalmente de reivindicar cuestiones sociales y cuando tocaban aspectos de carácter político era para apoyar las reivindicaciones masculinas. Entre dichas asociaciones destacó la ANME (Asociación Nacional de Mujeres Españolas) siendo la organización feminista más importante de España en aquel momento. Formada por mujeres de clase media, preparadas intelectualmente, entre las que destacaban Clara Campoamor y Victoria Kent que fueron luego constituyentes republicanas.

Clara Campoamor defendió en las Cortes Constituyentes de 1931 los derechos de la mujer. En defensa de la República y basándose en motivos de conciencia postuló la realización política de la mujer como una necesidad del régimen que, para cambiar la faz de España, tenía que destruir el divorcio ideológico que implicaba la sumisión de la mujer al hombre en las relaciones de los sexos. Defendió dichos derechos contra la oposición de los partidos republicanos con gran presencia en el Parlamento; obtuvo el apoyo de los votos del Partido Socialista (no en su totalidad) y de algunos núcleos republicanos. También votaron las derechas a favor de la concesión del voto femenino. Conviene destacar la oposición de amplios sectores del arco parlamentario a reconocer en ese momento el voto a la mujer (destaca la intervención en contra de Victoria Kent) porque se alegaba la 
falta de preparación al respecto y que por ello se pensaba que su actuación se vería influenciada por el marido y por la iglesia católica.

A pesar de la relevancia del hito histórico que supuso el reconocimiento del derecho de sufragio activo y pasivo a la mujer en la Constitución de 1931, ésta sólo pudo ejercer dicho derecho en dos ocasiones, en las elecciones de 1933 y de 1936 a Cortes Generales; el levantamiento militar y la posterior guerra civil dieron al traste con la experiencia republicana. El voto femenino fue mal interpretado y el éxito de las tesis sufragistas quedó oculto a pesar de los éxitos cosechados en pro de los derechos de la mujer. A Clara Campoamor su partido político la condenó al ostracismo y quedó marginada y abandonada en el exilio por el Gobierno de la República. Así redimía su pecado mortal: el voto femenino.

El golpe de Estado de 18 de julio de 1936 dio lugar a la cruenta Guerra Civil que duró largos años y terminó con el derecho de sufragio de los ciudadanos españoles de ambos sexos. La dictadura franquista se prolongó cuarenta años a lo largo de los cuales las convocatorias electorales a los plebiscitos, previamente orquestados por la dictadura, se organizaban para garantizar la permanencia en el poder del Jefe del Estado. En este ambiente, ausente la democracia, la mujer no quedó relegada del simulacro de participación política; en los referendos las mujeres fueran casadas o solteras podían «votar» en igualdad de condiciones que los hombres.

Pero el régimen de Franco eliminó todos los derechos de las mujeres conseguidos durante el periodo republicano. Su objetivo era devolver a la mujer al ámbito de lo privado liberándola «del taller y de la fábrica» y volviendo a someterla a la autoridad marital. Una gran activista por la defensa jurídica de los derechos de la mujer en las últimas décadas de la dictadura franquista fue la jurista María Telo Núñez, cuya obra jurídica y política fueron decisivas para la reforma del Código Civil ya que antes de ser reformado el art. 2.263 de dicho norma situaba a la mujer casada entre los menores, los locos... y quienes no sabían leer ni escribir. El art. 57 obligaba a la mujer a obedecer al marido y la licencia marital le acompañaba en todos los actos de la vida. Sin licencia la mujer casada sólo podía hacer testamento. Los trabajos en que tanto empeño puso culminaron con la promulgación de la Ley 14/75 de 2 de mayo de 1975 que devolvió a la mujer su capacidad plena de obrar al eliminar la obediencia al marido, la licencia marital y todas las discriminaciones por razón de sexo excepto la patria potestad conjunta y la administración conjunta de los bienes gananciales.

La muerte del General Franco el 20-XI-1975 permitió el comienzo de la transición política en España y recuperar la democracia. El cuerpo social español estaba preparado para la reincorporación de la mujer a participar en los asuntos públicos y a ejercer en condiciones de igualdad el derecho de sufragio activo y pasivo. Así pues, el Referéndum para la aprobación de la Ley para la Reforma Política de diciembre de 1976 se convocó conforme a la vigente legislación franquita y las mujeres participaron en idénticas condiciones que los hombres. Aprobada dicha Ley quedó expedito el camino para la convocatoria de elecciones a 
Cortes Constituyentes para lo cual fue necesario aprobar el Real Decreto en marzo de 1977 que regulara un inexistente procedimiento electoral. Dicho Decreto concedía el derecho de sufragio activo y pasivo tanto a los hombres como a las mujeres en pleno uso de sus derechos civiles y políticos. La convocatoria electoral de 15 de junio de 1977 fueron las primeras elecciones democráticas generales que, desde 1936, se celebraban en España donde toda la ciudadanía participó en condiciones de igualdad.

\section{TERESA FREIXES SANJUAN}

Fue un reconocimiento importante, pero que hoy consideraríamos «tímido», porque conceptualmente la igualdad y no discriminación, por razón de sexo o de orientación sexual ha evolucionado mucho.

En 1977 no teníamos Constitución y las normas legales contenían todavía muchas discriminaciones. Por ejemplo, en el Código Civil se disponía que no tenían capacidad de obrar los menores, los enajenados y las mujeres casadas. Hoy estamos a años luz de estas regulaciones, puesto que la capacidad jurídica de obrar de las mujeres es la misma que la de los hombres. Los problemas no están en las regulaciones jurídicas sino en la vida práctica.

\section{ITZIAR GÓMEZ FERNÁNDEZ ${ }^{4}$}

La Constitución republicana del año 1931 tiene algo de mito fundador, en la medida en que reconoció a las mujeres la condición de sujeto pleno de derechos, y particularmente la titularidad del derecho de sufragio, tanto en su dimensión pasiva como en su vertiente activa. Ese elemento diferencial respecto del contexto normativo previo, y la intensidad de los debates habidos en torno a esta cuestión, nos hacen volver la vista a la Constitución de la II República española cada vez que hablamos sobre mujer y constitucionalismo en España. Si el constitucionalismo se funda y sostiene sobre un conjunto de mitos fundadores, de entre los que destaca el del contrato o pacto social, la historia del pensamiento y logros feministas, en parte, también.

En todo caso, si bien el hito normativo se identifica con la Constitución de 1931, el debate teórico y político sobre los derechos de la mujer en España había empezado antes, y no se cerraría con la aprobación de los artículos 25, 36 y 53 de la Constitución republicana.

4 Buena parte de mis respuestas a esta encuesta se basan en el estudio elaborado para el libro Una Constituyente feminista ¿Cómo reformar la Constitución con perspectiva de género?, publicado por Marcial Pons en diciembre de 2017 (Colección «Debates Constitucionales»). En algunos casos se toman fragmentos literales del trabajo. 
El Decreto de 8 de mayo de 1931 modificó la Ley Electoral de 8 de agosto de 1907, ampliando la titularidad del derecho de sufragio pasivo a las mujeres, sin las limitaciones que se establecían en la legislación previa. Esta modificación normativa permitió que dos mujeres integraran las que serían Cortes Constituyentes: Clara Campoamor y Victoria Kent, ambas elegidas por la circunscripción de Madrid. Terminada la discusión del texto constitucional, Margarita Nelken formaría parte también de la Cámara Baja, elegida por la circunscripción de Badajoz. Clara Campoamor fue, además, integrante de la Comisión parlamentaria que redactó el borrador de la Constitución y, como ponente, fue la encargada de la defensa ante el Pleno del artículo que extendía el derecho de sufragio activo a las mujeres. El debate, como recordamos, fue encendido y se retomó varias veces, discutiéndose no sólo el qué, sino el cómo, cuestión esta que me parece interesante destacar aquí. En un momento dado, la discusión basculó de la idea del reconocimiento o no de la igualdad de derechos, incluido el de sufragio, a la cuestión de si el reconocimiento debía formularse en el texto constitucional o debía quedar para una sucesiva regulación legal. Una vez constitucionalizado el derecho de sufragio activo en el art. 36, se intentó la introducción de una disposición transitoria en la Constitución para demorar la entrada en vigor de dicho precepto. El temor a que el voto de las mujeres fuera un voto «contra-republicano» pesaba sobremanera en la reflexión política de los Diputados, pero la defensa de Clara Campoamor de la imperiosa necesidad de que el voto femenino se reconociese con carácter inmediato, acabó por convencer a la estrecha mayoría que rechazó la enmienda referida a la disposición transitoria. 131 Diputados frente a 127. Cuatro votos de diferencia. Cuatro votos que marcaron la gran diferencia.

La primera reflexión que me inspira la lectura de los debates constituyentes de 1931, y de la prensa de la época, es que el movimiento sufragista en España tenía una fuerza muy relativa, y muy mediatizada por la asunción que, dentro de los partidos progresistas de la época, se hizo de las pretensiones del sufragismo. Algo que sucedería, de nuevo, en 1977, en los debates constituyentes previos a la aprobación de la Constitución de 1978. Los intereses de partido estuvieron en 1931, como en 1977, por encima de cualquier otra consideración. Y tanto los avances observados, como aquellos que no se produjeron, son el resultado directo de que determinados partidos políticos asumieran o no las pretensiones del movimiento feminista, en sus respectivas modalidades históricas.

La otra gran reflexión que me hago tiene que ver con la inserción, en el texto constitucional del 31, de un conjunto de medidas de equiparación entre hombres y mujeres que después se perderían y no habrían de recuperarse siquiera con el texto de la Constitución de 1978. Los arts. 48, 49 y 50 consagraban un modelo educativo integrador, con una escuela única, gratuita, obligatoria en la enseñanza primaria y una educación igualitaria y laica. La cuestión de la educación de las mujeres había sido el eje vertebrador del "protofeminismo» español. Los textos de Emilia Pardo Bazán, Concepción Arenal, Rosalía De Castro, Cecilia Böhl de Faber, Gertrudis Gómez de Avellaneda o Carmen de Burgos evocaban, con 
diversos matices, la necesidad de reforzar la educación de las mujeres, como eje en torno al cual debía articularse el cambio de paradigma social, y la Constitución republicana recoge la vindicación y la fórmula como derecho fundamental. El texto también legitimaría la integración de las mujeres en el mundo laboral (arts. 33 y 40 C'31), los derechos al matrimonio civil y al divorcio (arts. 41 y 43 C’31), la despenalización del adulterio, y la atribución de la patria potestad a las mujeres.

Con el alzamiento militar de 1936, y la victoria de quienes lo promovieron en 1939, se inició un periodo de retroceso manifiesto en todos y cada uno de los avances señalados. $Y$ con el fin del régimen franquista, hubo de recuperarse el discurso que se formulara ya durante la Segunda República en relación con la educación, la incorporación de la mujer al mundo laboral y la recuperación del estatuto igualitario en las relaciones familiares. En 1977, en los temas que hemos señalado, se volvió al punto en que se había quedado el debate 40 años antes, con el agravante de que, cuatro décadas de dictadura, habían hecho calar determinados planteamientos en un amplio grupo de población con la que había que consensuar las bases del nuevo sistema democrático. Y en la Constitución de 1978 no se logró alcanzar el nivel de reconocimiento y alcance que determinados derechos tuvieron en la Constitución de la II República. La gran diferencia entre los dos modelos radica en el hecho de que la estabilidad política alcanzada tras la Constitución de 1978 permitió recuperar con rango legal el territorio conquistado en los años 30, consolidarlo y desarrollarlo posteriormente.

\section{FERNANDO REY MARTÍNEZ}

Hubo interesantes intentos de reconocer cierta igualdad jurídica y política entre mujeres y hombres antes de 1931 en nuestro país, en idéntica línea de lo que sucedía en otros países europeos. Las primeras protestas feministas tenían, sin embargo, un objeto limitado; ni mucho menos pretendían la plena equiparación de derechos entre mujeres y hombres ni partían de la consideración de la radical igualdad entre ambos, dado que aún las sociedades europeas no se habían secularizado tanto como para convenir que mujeres y hombres no tuvieran distintas funciones sociales que cumplir (producción y mando, los hombres, reproducción y obediencia, las mujeres). Religiones y tradiciones, sobre todo ligadas a una cierta idea de «familia», venían a impedir cambios excesivamente bruscos en el imaginario social del periodo. En efecto, el primer feminismo, de finales del siglo XIX y comienzos del XX, llevaba en el zurrón de sus propuestas temas tan concretos y limitados como el acceso de las mujeres solteras a las profesiones (no de las casadas); el derecho de las mujeres casadas a administrar su propio patrimonio; la mejora de la educación de las mujeres y el ingreso de éstas a los estudios superiores... y el sufragio femenino. Poco más. Aunque no era poco, ni poco importante $\mathrm{o}$, ni mucho menos, fácil de conseguir. Y eso que, como puede observarse, eran 
reivindicaciones propias no tanto de todas las mujeres, sino de los grupos más activos de las mujeres de las clases posidentes e ilustradas.

En mi opinión, el cambio ideológico o de mentalidad que lleva a considerar a mujeres (a todas ellas) y hombres como sujetos plenamente iguales y, por tanto, con idénticos derechos, no empieza a abrirse paso, en realidad, sino a partir del cambio axiológico asociado al nivel de desarrollo económico y cultural de las sociedades europeas y norteamericanas alcanzado a partir de los años sesenta del siglo Xx. Mayo del 68. Que coincide, además, en el tiempo y creo que de modo no casual, con la incipiente generalización de los anticonceptivos y, por tanto, con el control de la propia maternidad, lo que permite, por fin, la conciliación entre «producción» (trabajo extradoméstico) y «reproducción». De ahí que, a mi juicio, la plena igualdad entre mujeres y hombres, tal y como la entendemos contemporáneamente, en realidad arranca constitucionalmente de verdad en nuestro país con la Constitución de 1978.

Esto no empequeñece, por supuesto, el valor histórico de los antecedentes, sobre todo del republicano. Asombra, por ejemplo, la lucidez, actualidad y coraje de Clara Campoamor en los debates de elaboración de la Constitución de 1931. Pero hay, incluso, precedentes interesantes, empezando desde la proposición de ley del conde de Casas-Valencia en el Senado de 1908 alegando que en España «las mujeres podían ser reinas, pero no electoras». O el intento, también en ese año, de reconocer el sufragio para las mujeres mayores de edad, emancipadas y cabezas de familia en las elecciones municipales (en 1907 se había generalizado el sufragio masculino), lo que fue rechazado en el Congreso por 65 votos en contra y 35 a favor. También cabe recordar el periodo de la Dictadura de Primo de Rivera y su pretensión de reconocer el voto femenino para la Asamblea Nacional Consultiva y para las elecciones municipales, siempre que no fueran «casadas ni prostitutas».

El Decreto de 8 de mayo de 1931, en los pródromos de la República, declaró a las mujeres elegibles pero no electoras. En el Congreso republicano constituyente, sólo hubo dos mujeres, Clara Campoamor, del partido radical y Victoria Kent, del partido radical socialista. La primera postuló el voto femenino con audacia y rigor lógico: ¿cómo reconocer constitucionalmente la igualdad en general y privar al mismo tiempo a las mujeres de sus derechos políticos? Tras el decisivo debate de la sesión de 1 de octubre de 1931 (un día que ella calificó «el gran día del histerismo masculino» por el tono de sus adversarios), se aprobó el histórico artículo 34: «Los ciudadanos de uno y otro sexo, mayores de 23 años, tendrán los mismos derechos electorales, conforme determinen las leyes» por 161 votos a favor, 121 en contra y 188 abstenciones. Sólo estaba presente el $60 \%$ de miembros de la Cámara. Enfrente, Victoria Kent, quien expresó la «inoportunidad» de esta medida dada la tradicional dependencia de las mujeres del ideario conservador y religioso. En sus propias palabras: «El voto femenino debe aplazarse... es necesario hacerlo porque yo necesitaría ver, para variar de criterio, a las madres en las calles pidiendo escuelas para sus hijos, yo necesitaría haber visto en las calles 
a las madres prohibiendo que sus hijos fueran a Marruecos... No es cuestión de capacidad, es cuestión de oportunidad para la República».

Incluso una vez aprobado el artículo 34 , los detractores del voto femenino plantearon, y casi obtuvieron éxito (perdieron la votación por 131 a 127), que el derecho de sufragio femenino se aplazara, mediante la correspondiente Disposición transitoria, hasta que no se renovaran los ayuntamientos entonces vigentes o, incluso, hasta ocho años después de aprobada la ley electoral.

A favor del voto femenino se pronunció el Partido Socialista (con alguna notable excepción, como la de Indalecio Prieto, que lo consideró «una puñalada» para la República), las derechas y algunos republicanos, sobre todo catalanes y vascos. En contra, los partidos republicanos (con la notoria excepción de Campoamor). En las elecciones siguientes, cuyo censo electoral pasó del $26 \%$ al $55 \%$ de la población, triunfó la derecha, la CEDA, pero es muy discutible que ello se debiera al voto femenino más que a los propios problemas y errores del gobierno anterior. Como curiosidad, sólo cuatro mujeres resultaron elegidas diputadas y ni Campoamor ni Kent fueron renovadas.

El franquismo hizo suyo un ideario de la mujer no ya ultraconservador, sino incluso pre-liberal. El lugar de la mujer es la iglesia y el cuidado de la casa y del marido, los padres y los hijos. Obviamente, en el periodo de la transición, cuarenta años después, se habían producido significativos cambios sociales y culturales, pero aún carecían de la capacidad de imponerse rápidamente y con claridad al modelo patriarcal tradicional.

\section{OCTAVIO SALAZAR BENÍTEZ}

La primera reflexión que me provoca recordar el proceso constituyente de 1931, y muy especialmente la lucha de Clara Campoamor por el reconocimiento de las mujeres como ciudadanas, es que el feminismo supone también un ejercicio de memoria. Es decir, una revisión de la historia, también de la constitucional, teniendo presentes a las que fueron excluidas y, por supuesto, a las que lucharon por romper con un modelo de «pacto social» construido sobre la universalidad del sujeto masculino y la «subordiscriminación», en palabras de M. Ángeles Barrère, de la mitad femenina. Justo cuando se cumplen los 40 años de vigencia de la Constitución de 1978, y en el contexto de lo que ya algunas voces denominan «cuarta ola feminista», es importante tener presente esa memoria, con frecuencia invisible, y no solo por un acto de justicia, que también, sino porque solo desde ella es posible hacer un análisis riguroso de las conquistas y de las debilidades de los sistemas constitucionales que se construyeron sobre la originaria exclusión de las mujeres del poder constituyente ... y de los poderes constituidos.

Las conquistas políticas y jurídicas que, desde el punto de vista de la igualdad de género, comenzaron a vislumbrarse en la II República, apuntaron el inicio de una ruptura con un modelo político y jurídico que a lo largo del XIX no había 
hecho otra cosa que prorrogar las estructuras patriarcales. Unas conquistas que apenas dispusieron de tiempo para cambiar una cultura, incluida en ella la dimensión constitucional, que continuaba estableciendo serios obstáculos para que mujeres y hombres fueran reconocidos como sujetos equivalentes. No hay que olvidar que los años 20 y 30 del pasado siglo marcaron el inicio de una transformación que permitió que las mujeres, algunas mujeres, tuvieran una presencia pública y un mayor protagonismo en la vida social y cultural del país. No obstante, los mayores obstáculos seguían estando en el marco jurídico. Recordemos como la periodista y pionera en tantos ámbitos, Carmen de Burgos, publicó en 1927 un libro titulado «La mujer moderna y sus derechos» en el que el diagnóstico era rotundo: «La base está en las leyes, en la proclamación de la "igualdad de derechos". Las costumbres han evolucionado mucho a favor de la mujer. Lo que necesita es que los códigos marchen de acuerdo con las costumbres y no pretendan fijar la vida en textos móviles». Un análisis que años atrás, en 1899, un hombre de leyes, Adolfo Posada, había desarrollado en su pionera obra Feminismo. Lamentablemente la suma de todos estos ingredientes y las pioneras conquistas republicanas no dispusieron del tiempo necesario para consolidar cambios sustanciales en la vida de las españolas.

En este sentido, el largo período de la dictadura supuso uno de los paréntesis más penosos en la evolución de los derechos de las mujeres en nuestro país, y la confirmación de que el patriarcado siempre ha tenido una singular capacidad para readaptarse y establecer alianzas con los poderes empeñados en mantener el orden. Ante la ausencia de estructuras democráticas, y negada la autonomía de las mujeres, el Derecho Civil - y junto a él también el Derecho Penal en su configuración, por ejemplo, de la «honestidad» femenina- se convirtió en el código de sujeción de las mujeres. En la norma que mantuvo y legitimó lo que desde el feminismo se ha denominado «contrato sexual» y que, en alianza con otras instancias, muy especialmente la Iglesia Católica, prorrogará un estado de subordinación de las españolas. Todas las estructuras de poder en las que se apoyó la dictadura franquista se empeñaron en mantener un estado de cosas que privilegiaba la continuidad de lo que Celia Amorós llama «pacto juramentado» entre varones y, en consecuencia, cómo alimentaron una cultura, entendida en el sentido más amplio del término, y por lo tanto con evidentes consecuencias también en el plano jurídico, basada en la diferenciación jerárquica entre hombres y mujeres.

El hecho de que en los momentos finales de la dictadura, y de manera más plena una vez aprobada la Constitución, se abordaran cambios sustanciales en ese Derecho Civil que durante siglos había mantenido el binomio poder masculino/sujeción femenina, debería ponernos sobre aviso a los y las constitucionalistas sobre una cuestión esencial. Me refiero a cómo ese espacio privado, el de la familia y lo doméstico, ha sido tradicionalmente excluido de la configuración del mismo concepto de «ciudadanía» y, en consecuencia, ha dado lugar a una división jerárquica también entre lo público y lo privado. Dos ámbitos ligados 
habitualmente al binomio masculino/femenino. Es decir, las conquistas jurídico-constitucionales de 1931, estrechamente vinculadas a lo que podríamos llamar ciudadanía de las mujeres, y la imperiosa necesidad en los años 70/80 del pasado siglo de resquebrajar los moldes jurídicos del «contrato sexual», deberían servirnos en el momento presente para poner el foco en las dos cuestiones que, a mi parecer, continúan siendo esenciales desde el punto de vista de la igualdad de mujeres y hombres. De un lado, la efectiva garantía de su presencia en lo público o, lo que es lo mismo, su pleno reconocimiento como ciudadanas, como sujetos (o, casi mejor, sujetas) con poder. De otro, la revisión de un marco relacional —afectivo, sexual, familiar - que todavía hoy, en pleno siglo XxI, y pese a todos los cambios vividos en el pasado siglo, continúa siendo en gran medida deudor de los esquemas patriarcales. Dicho de otra manera, el ejercicio de memoria constitucional que supone revisar nuestro siglo Xx con perspectiva de género nos pone en evidencia que sigue estando pendiente la redefinición del mismo concepto de ciudadanía y, con él, de lo que entendemos como sujeto (y sujeta) de los derechos que nos han permitido superar la categoría de súbditos (y súbditas). Es decir, y como bien ha explicado la constitucionalista Blanca Rodríguez, todavía hoy es necesario superar «la construcción sexuada de la ciudadanía moderna, la que la divide en dos modelos dicotómicos: la ciudadanía activa de los varones, que asume su independencia y se despliega en el espacio público, y la ciudadanía pasiva de las mujeres, basada en la noción de dependencia y centrada en lo doméstico». Y ello pasa, lógicamente, en gran medida, por cuestionar la posición privilegiada que los hombres tenemos en este sistema y por redefinir, en consecuencia, nuestra posición tanto en lo público como en lo privado. Tarea imposible mientras que el modelo de referencia sea el del «diligente buen padre de familia».

2. ¿Cómo valora la forma en que la Constitución de 1978 recoge la igualdad entre mujeres y hombres? ¿En qué medida puede ser el reflejo del número de mujeres constituyentes? ¿Cómo explica que este tema apenas ocupase espacio en los debates constituyentes?

\section{MARIA LUISA BALAGUER CALLEJÓN}

La Constitución recoge la igualdad entre mujeres y hombres en el art. 14 cuando reconoce el derecho de igualdad sin que pueda prevalecer ninguna discriminación por diversos motivos entre los que se encuentra el sexo. Pero también son preceptos que repercuten en la igualdad de las mujeres, el art. $15 \mathrm{CE}$, el art. $32 \mathrm{CE}$ y el art. $39 \mathrm{CE}$. Por lo que se refiere al art. $15 \mathrm{CE}$, la redacción ambigua de que «todos tienen derecho a la vida», permitió una primera ley de despenalización de determinados supuestos de interrupción voluntaria del embarazo, 
que fue validada en el trámite de recurso previo de inconstitucionalidad, y posteriormente sustituida por la LO 2/2010, de 3 de marzo, de salud sexual y reproductiva y de la interrupción voluntaria del embarazo. En lo que se refiere al art. $32 \mathrm{CE}$, al reconocer en su pf. 1. ${ }^{\circ}$ la igualdad de derechos del hombre y de la mujer en orden a contraer matrimonio, deja establecidos los principios de igualdad que permitirán revisar algunos preceptos del código civil, en el pf. 2. ${ }^{\circ}$ al establecer el mandato de una regulación legal de la institución matrimonial, dará entrada de manera implícita a la institución del divorcio.

El art. 39 CE, dentro de los principios rectores de la política social y económica, asegura la protección de la familia, la igualdad de los hijos ante la ley, con independencia de su filiación, y la obligación de prestar asistencia de los padres, dentro y fuera del matrimonio. La posibilidad de investigación de la paternidad, es igualmente un derecho que repercute en la libertad de las mujeres y en la posibilidad de exigir responsabilidades a quienes pueden ser padres de los hijos que ellas cuidan y educan.

Con todo, no puede decirse que en la Constitución Española de 1978 se haya atendido de manera suficiente a las necesidades o peticiones de las mujeres, en la medida en que algunas normas, como el art. 57.1 CE regularon la preferencia del varón sobre la mujer en la línea sucesoria a la jefatura del Estado, o faltaron preceptos importantes que hicieran referencia a la situación de retraso de la mujer en sus derechos laborales, estableciendo algunos mecanismos compensatorios de reparación. Las excedencias forzosas, como se verá apenas pudieron aplicarse, al estar sometidas a plazos de prescripción de las acciones procesales laborales de tres años. Será el Tribunal constitucional el encargado de desarrollar de manera progresista en los años siguientes esos derechos de la mujer en los diferentes órdenes jurisdiccionales.

Naturalmente, la escasa presencia de mujeres en las Cortes constituyentes tuvo que ver con este escaso reconocimiento de las mujeres en el texto constitucional, pero si se consultan los Trabajos Parlamentarios, puede observarse que las intervenciones de las mujeres en los debates fueron importantes, como en el caso referido del art. 57.1 CE.

\section{PALOMA BIGLINO CAMPOS}

No me parece que, a pesar de la situación en la que las mujeres se todavía se encontraban en 1978 y la escasa representación que tuvieron en las Cortes que elaboraron nuestra norma fundamental, la regulación de la igualdad en la Constitución fuese insatisfactoria. Tampoco me parece que lo siga siendo ahora, aunque como veremos más adelante, sería necesario introducir algunos cambios.

Desde un punto de vista histórico, es un error pretender valorar el pasado usando como parámetro de juicio la mentalidad del presente. La Constitución fue un gran avance si tenemos en cuenta que la sociedad española de 1978 seguía 
siendo profundamente discriminatoria. Esta mentalidad predominaba entre los sectores conservadores, que pretendían confinar a la mujer a ámbitos puramente domésticos, sometida a lazos de dependencia económica con respeto al marido. Este tipo de planteamientos tampoco era ajeno a algunos sectores de los denominados progresistas. Si examinamos las cúpulas de los partidos o los candidatos presentados a las primeras elecciones, es fácil detectar que algunas de esas fuerzas políticas todavía consideraban que el papel de las mujeres quedaba relegado a bordar la bandera revolucionaria en casa. La excepción a esta tendencia fueron los movimientos feministas que aparecieron durante la transición y la acción de algunos hombres y mujeres que, desde dichos movimientos y desde los partidos recientemente legalizados, exigieron la plena igualdad jurídica y mayor igualdad de oportunidades.

Es cierto que el tema de la igualdad entre sexos no recibió demasiada atención durante los debates constitucionales. Pero no me parece que este silencio fuera debido a desinterés por el asunto, sino a que el principio no admitía discusión. Como veremos más adelante, estaba proclamado en las principales declaraciones internacionales de derechos y era un principio que también aparecía recogido en las Constituciones que nos sirvieron de referencia, como eran la italiana, la alemana y la francesa En general, puede afirmarse que tanto en 1978, como en la actualidad, la Constitución trata el tema de una manera no muy distinta a la que predominaba, y sigue predominando, en los principales instrumentos supranacionales y en otros países democráticos de nuestro entorno.

La principal decisión del constituyente consistió en proclamar la igualdad formal en el art. 14, prohibiendo, entre otras discriminaciones, las fundadas en el sexo. El art. 32 sigue el mismo espíritu, al reconocer al hombre y la mujer la plena igualdad jurídica en el matrimonio. La única excepción a esta regla general es la preferencia del varón sobre la mujer en la sucesión a la corona regulada en el art. 57.1, cuya sola explicación quizá fuera las circunstancias que rodearon a la transición. Como más adelante podré argumentar, me parece necesario cambiar este precepto, pero más por razones simbólicas que efectivas.

Además, nuestra Norma fundamental también deja abierta la puerta para ir más allá de la igualdad formal cuando, en el art. 9.2, atribuye a los poderes públicos la misión de promover las condiciones para que la igualdad sea más efectiva lo que puede aplicarse, y de hecho se aplica, a las mujeres.

Esta orientación ha tenido algunas ventajas. En primer lugar, para dar cumplimiento al mandato del art. 14 y a partir de la entrada en vigor de la Constitución, se reformaron aquéllas leyes civiles y penales que discriminaban a la mujer y vulneraban directamente la igualdad de trato. Además, la Constitución respetó la libertad de configuración del legislador, que según la mayoría parlamentaria ha ido adaptando la igualdad a sus propios planteamientos ideológicos. El mandato establecido en el art. 9.2 ha permitido, en efecto, la adopción de medidas en favor de las mujeres como han sido, por ejemplo, las listas electorales de composición equilibrada. También en esta cuestión se pone de 
manifiesto el carácter conciliador de la Norma fundamental, que ha permitido políticas diferentes, variando desde la máxima «la que vale, sale» hasta las listas electorales de composición equilibrada.

Ahora bien, la opción constitucional tiene también sus inconvenientes. El principal de todos ellos es que no impide retrocesos en la posición que las mujeres han alcanzado hasta el momento. Esta hipótesis, que antes resultaba casi impensable, comienza a ser propugnada por fuerzas políticas que, aunque minoritarias, cuentan ya con representación parlamentaria y son la llave de la gobernabilidad de una Comunidad Autónoma. Es verdad que incluir en la Constitución medidas favorables a las mujeres no las hace inquebrantables, sobre todo frente a quienes repudian nuestra norma fundamental. Pero, al menos, evita que otras fuerzas políticas, respetuosas de la Constitución, sientan la tentación de rebajar su grado de compromiso con la igualdad de género.

\section{ÁNGELA FIGUERUELO BURRIEZA}

Las Cámaras que resultaron de las elecciones generales de junio de 1977 fueron fiel reflejo de la sociedad española del momento, marcada entre otras cuestiones por la desigualdad real entre hombres y mujeres y basada en la tradición secular de discriminación e invisibilidad que en los distintos aspectos de la vida política, social, cultural, económica... había sufrido ese más del cincuenta por ciento de la población que representamos las mujeres. No es de extrañar, pues, que sólo veintisiete mujeres - 21 diputadas y 6 senadoras - formaran parte de las Cortes Constituyentes. Fueron poco más del cinco por ciento del total de los parlamentarios, pero su presencia en la Cámaras y sus aportaciones fueron algo más que testimoniales. Defendieron las reivindicaciones feministas y trabajaron para perfeccionar la norma suprema. Su escasa presencia representaba el símbolo de la recuperación del derecho a la ciudadanía; recogían el testigo de Clara Campoamor y del resto de las predecesoras en la lucha por el reconocimiento de los derechos de la mujer y en esa línea trabajaron en la reforma de algunos principios legales procedentes de un régimen político repleto de normas discriminatorias. Era la segunda vez en la historia de nuestro constitucionalismo que un reducido número de mujeres formaban parte del órgano legislativo soberano en calidad de sujetos de derecho.

La redacción de la Constitución de 1978 se llevó a cabo con la ausencia del enfoque que hubiera aportado la perspectiva de género. Toda ella está escrita en masculino genérico (en cuanto género no marcado). En la Ponencia Constitucional que redactó el Anteproyecto de Constitución sólo participaron siete hombres (siete padres de la norma suprema) y en la Comisión de Asuntos Constitucionales, sólo estuvo presente - a petición propia - una mujer: María Teresa Revilla López, del partido conservador de la UCD. En consecuencia, la vigente norma fundamental del Estado Español, como consecuencia de la situación política 
interna y de la influencia del constitucionalismo europeo del momento, reconoció la igualdad en sus variantes manifestaciones que conllevan diferentes grados de eficacia y posibilidades distintas de interpretación: la igualdad como valor superior del ordenamiento jurídico se reconoce en el art. 1.1 de la CE que impregna todo el derecho vigente, además de la configuración que obtiene a lo largo de todo el texto constitucional que a su vez le otorga un valor jurídico de principio con todos los efectos interpretativos y de vinculación al legislador que le corresponden a todos los principios constitucionales.

La igualdad como derecho público subjetivo o igualdad ante la ley en su sentido formal se reconoce en el art. 14 de la CE. Dicho precepto recoge también una cláusula antidiscriminatoria que señala ciertas categorías sospechosas de discriminación como el nacimiento, la raza, el sexo, la religión, la opinión... Así las manifestaciones concretas de la igualdad y no discriminación en la ley de leyes aparecen en el art. 23.2 que reconoce el acceso a cargos y funciones públicas en condiciones de igualdad; la exigencia del respeto a la igualdad en lo referente a los deberes fiscales se reconoce en el art. $31.1 \mathrm{y}$ en el art. $32.1 \mathrm{el}$ derecho a contraer matrimonio con plena igualdad jurídica; la prohibición de discriminación por razón de sexo en las relaciones laborales se constitucionaliza en el art. 35.1 y la igualdad de los hijos ante la ley con independencia de su filiación aparece reconocida en el art. 39.2 (en el ámbito de los denominados principios rectores de la política social y económica).

La igualdad formal del art. 14 constitucional se complementa con el contenido del art. 9.2 de la misma norma que alude al complemento material de dicho principio y que integra el postulado social del actual modelo de Estado (art. 1.1 de la CE). Se trata del alcance promocional de la igualdad como obligación de los poderes públicos de facilitar las condiciones para que la igualdad individual y grupal sean reales y efectivas; para lo cual se deberán eliminar los obstáculos que impidan o dificulten su plenitud. Dicha cláusula potencia el alcance antidiscriminatorio y las medidas adoptadas por los poderes públicos dirigidas a posibilitar de facto el cumplimiento de las finalidades constitucionales.

A pesar del potencial interpretativo que en cuanto principio contenía el art. 14 de la CE, regulando la igualdad de todos los españoles ante la ley y prohibiendo la discriminación por razón de sexo. Las discusiones parlamentarias en sede constituyente no ponen de relieve los problemas referentes a la igualdad de mujeres y hombres que en aquellos momentos reclamaba con insistencia el movimiento feminista. Únicamente las intervenciones de la diputada Sra. Revilla López vincularon dicho precepto constitucional con la desigualdad histórica sufrida por las mujeres. El hecho de que la Constitución reconozca al sexo entre las categorías sospechosas de discriminación es debido a que las mujeres, conocidas como el sexo débil, han sido objeto de dominación por el patriarcado a lo largo de los tiempos. La aprobación del art. 14 constitucional posibilitó que las mujeres españolas adquiriesen, al menos formalmente, la plenitud de derechos. El movimiento feminista incluyó entre sus reivindicaciones históricas el derecho 
a la igualdad de mujeres y hombres como la consecuencia más evidente de la implantación de un sistema constitucional democrático.

El reconocimiento del derecho a la igualdad en la CE de 1978 significó para las mujeres españolas la puerta que se abría hacia el futuro para ser finalmente protagonistas de sus vidas y poder participar en condiciones de igualdad en la configuración de una sociedad democrática avanzada. Pero, esto no era suficiente; la igualdad formal como punto de partida no garantizaba la igualdad material (real y efectiva) como punto de llegada. Para ello eran imprescindibles numerosos cambios en la vida social, política y económica... que permitiesen la incorporación de la mujer a la vida pública, a lo cual tenía derecho en las mismas condiciones que los hombres. La vigente Constitución aprobada hace ya cuarenta años es el fruto de unas Cámaras que reflejaban la sociedad española del momento. Las veintisiete mujeres presentes en la legislatura constituyente se esforzaron por perfeccionar el texto constitucional pero las circunstancias del momento no les permitieron llegar más lejos.

\section{TERESA FREIXES SANJUAN}

La Constitución de 1978 incluye la no discriminación por razón de sexo, no la igualdad de mujeres y hombres, del mismo modo que la regulaban, entonces, los textos constitucionales que contenían alguna referencia al tema (en muchos no existía referencia alguna). Hemos de contextualizar la época, tanto para apreciar la fórmula constitucional como el escaso número de mujeres en la asamblea constituyente. En pocos lugares se contaba con regulaciones más pro-activas y con representación importante de las mujeres en las asambleas legislativas.

\section{ITZIAR GÓMEZ FERNÁNDEZ}

Podría decirse que un consenso constitucional amplio fraguado, entre otras, sobre la renuncia a la mayor parte de las reivindicaciones feministas, aseguró la paz y estabilidad social necesarias para avanzar posteriormente hasta el punto en que hoy nos encontramos, tanto en la cuestión de la agenda feminista como en muchas otras cuestiones. Y desde ese punto de vista la valoración debe ser positiva pero sin caer en la autocomplacencia, y reconociendo que en la Constitución hay silencios atronadores que han ido llenándose de contenido con el tiempo, la legislación, la jurisprudencia, el feminismo institucional y el activismo de las mujeres en las calles.

En todo caso, no resulta sencillo, y seguramente tampoco resultaría justo, formular una crítica a la forma en que la Constitución de 1978 recogió la igualdad entre hombres y mujeres, desde la óptica que hoy tenemos. Podría decir que hago una valoración positiva de la consagración de la igualdad formal y la 
igualdad material que recogen los arts. 14 y 9.2 del texto constitucional, respectivamente. Me parece que son los dos pilares imprescindibles sobre los que se ha construido el edificio de las reformas legales subsiguientes que nos han traído hasta donde nos encontramos actualmente, que es un marco normativo merecedor de una valoración globalmente positiva. A ello me referiré más adelante.

Pero hoy, 40 años después, creo que no debiéramos seguir expandiendo las posibilidades que nos ofrecen los preceptos citados sin consolidar constitucionalmente algunas de las conquistas legales realizadas. Porque la falta de consagración constitucional lleva implícito un riesgo de reversibilidad que debería ser minimizado. Y por esa misma razón mi valoraciónde la Constitución de 1978 en materia de igualdad, en tiempo presente y con las precauciones antes apuntadas, se resume acudiendo a la palabra «insuficiente». El texto, hoy, es insuficiente. Pero no creo que lo fuera en 1978, porque permitió dar paso a lo que yo definiría como una auténtica revolución legal.

La pregunta de si las falencias que pudieran detectarse en la Constitución se deben al número de mujeres constituyentes, presupone que este era bajo, y efectivamente lo fue, pero también coloca la responsabilidad de la insuficiencia del texto, de algún modo, en la ausencia de mujeres, o en la incapacidad de las mismas para promover un debate más amplio, y no me parece que esa lectura sea apropiada. Como tampoco creo que pueda hacerse una revisión retrospectiva del tiempo y extensión que ocuparon las discusiones en los debates constituyentes sobre la igualdad, para extraer la conclusión de que el tema no resultaba particularmente interesante para los y las constituyentes.

Creo que la Constitución es fiel reflejo de su tiempo, y de los intereses políticos predominantes, destacando de entre estos últimos la voluntad de tránsito a un sistema democrático por encima de cualquier otra cosa. No creo que más mujeres en las Cortes hubieran conseguido más avances, porque no eran ellas las protagonistas del debate esencial, y porque en la agenda de los partidos que protagonizaron ese debate, tan pronto pasaron las elecciones de 1977, desaparecieron algunos de los temas fundamentales de las reivindicaciones del movimiento de mujeres. El Partido Comunista, en la campaña electoral de las Elecciones a Cortes convocadas por el Real Decreto 679/1977 de 15 de abril, defendió el divorcio, el aborto y el uso de anticonceptivos. El Partido Socialista, por su parte, abogó por el reconocimiento de la igualdad formal y la igualdad de los hijos independientemente de su filiación matrimonial, y por el divorcio. Ni el divorcio, ni el aborto, ni el derecho a la libre determinación de la salud sexual y reproductiva, y por tanto de la elección de la planificación familiar entraron en el texto constitucional, aunque se abordó su regulación legal en la primera década posterior a la aprobación de la Constitución. Ello podría indicarnos que en el discurso político constituyente, se arrinconaron los postulados claramente vinculados a la corriente de pensamiento feminista. Si de la discusión parlamentaria previa a la aprobación de la Constitución de 1931 se recuerda, entre otros debates, el que giró en torno al reconocimiento del derecho de sufragio de las mujeres, de la redacción de la 
Constitución de 1978 no se recuerda más debate sobre la igualdad de hombres y mujeres que el vinculado a la sucesión a la Corona, cuestión obviamente bien alejada de las preocupaciones principales de un movimiento feminista que, en España, se vinculaba en la época de la transición a las posiciones políticas de la izquierda de corte republicano.

La causa de tal postergación no pude ser identificada como única, ni basarse en consideraciones meramente numéricas relativas a la escasa presencia femenina en las Cortes constituyentes. Está claro que el feminismo «intrapartidos» no tuvo una posición suficientemente fuerte. También lo está que sólo fueron 21 las Diputadas constituyentes. El 6\% de los candidatos electos. Solo una mujer, a petición propia, se integró en la Comisión sobre la Constitución, pero no fue ponente. De las seis Senadoras, dos fueron ponentes de sus respectivas Comisiones. Pero ninguna lideró, de forma visible, la negociación sobre los temas definitorios de las reivindicaciones feministas. ¿Tuvo que ver eso con la falta de desarrollo constitucional de algunos temas, como por ejemplo los citados? Es posible, pero creo que, sobre todo, tuvo que ver con la forma en que se debatieron los contenidos del texto constitucional, fuera muchas veces de la Carrera de San Jerónimo, con quienes gestionaron esos debates, que fueron solo en parte los miembros de la Ponencia constitucional, y con la priorización de objetivos a alcanzar, que dejaron fuera debates ideológicamente imposibles, para permitir los avances en la redacción del texto.

\section{FERNANDO REY MARTÍNEZ}

En las Cortes constituyentes tan sólo hubo 27 diputadas y 6 senadoras, pero su papel político fue menor. No hubo en este periodo algo parecido al brillante momento que protagonizaron Clara Campoamor y Victoria Kent en 1931. Tan sólo algunos gestos testimoniales, sobre todo en relación con la preferencia del varón sobre la mujer en orden a la sucesión monárquica. Los partidos políticos impusieron su disciplina sin fisuras (el margen de libre actuación de las diputadas —y los diputados - era limitado; dudo que su participación hubiera sido más decisiva aunque hubieran sido muchas más); el texto constitucional reconoció la igualdad entre mujeres y hombres en diversos preceptos sin mayores problemas (salvo la cuestión pendiente, pero aún lejana, del aborto); en ese periodo existía la impresión de que había muchas otras cuestiones políticas de mayor envergadura que la de la igualdad entre mujeres y hombres (la recuperación plena de la democracia y los derechos; la cuestión territorial; la correcta ocupación en el espacio institucional de los denominados «poderes fácticos», etc.); por otro lado, las doctrinas tradicionales de izquierda postulaban la emancipación de los obreros en general, sin enfoque de género; la situación de la igualdad de género tampoco era en la España de los años setenta notablemente distinta y peor que en la mayoría de Estados que ya eran democráticos por entonces... Todo esto explica que, 
inicialmente, la igualdad entre mujeres y hombres no pareciera una de las cuestiones constitucionales centrales. A pesar, por supuesto, de la existencia de pequeños, pero muy activos, grupos de feministas. A mi juicio, el cambio cualitativo se producirá cuando, en los primeros años ochenta, el PSOE va incorporando los postulados de las feministas socialistas del momento, con hitos como el de la creación del Instituto de la Mujer y, sobre todo, de la cuota del 25\% para los cargos orgánicos y los puestos de representación. Las críticas recibidas fueron enormes y provinieron de todos los lados, pero esta dinámica se acabó imponiendo, de modo formal o fáctico, en todos los partidos.

La Constitución recoge la igualdad entre mujeres y hombres de modo impecable. La cláusula general antidiscriminatoria se halla en el artículo 14, pero también hay previsiones expresas respecto del matrimonio (art. 32) o del trabajo (art. 35) y de modo implícito en la educación (art. 27.2) Otra cosa es que las inercias patriarcales sean robustas y cueste conseguir la igualdad real.

\section{OCTAVIO SALAZAR BENÍTEZ}

Es que la CE no recoge la igualdad entre hombre y mujeres. Como han denunciado constitucionalistas como Mar Esquembre o Itziar Gómez, existe un pecado de omisión en el texto constitucional que solo cabe purgar modificando el texto constitucional. Uno de los grandes déficits democráticos del texto de 1978 es que las mujeres están ausentes no solo del articulado sino de lo que podríamos llamar el «relato» político sobre el que se sostiene ese pacto de convivencia. Como bien ha explicado la filósofa del Derecho Ana Rubio, las mujeres no participaron del poder constituyente. No estuvieron en ese poder originario, tal y como ha sido la regla en el constitucionalismo liberal. El consenso se construyó si ellas o, como mínimo, sin tener en cuenta las reivindicaciones feministas. Una ausencia que lógicamente debería hacer que nos cuestionáramos la misma legitimidad del pacto, porque, ya lo advirtió Olimpia de Gouges en 1791, «la Constitución es nula si la mayoría de los individuos que componen la Nación no ha cooperado en su redacción.»

Algo que el lenguaje, siempre tan expresivo de las relaciones de poder que lo alimentan, nos deja muy claro cuando nos insiste en la imagen de «los padres de la Constitución». Por supuesto que hubo mujeres en el proceso constituyente, las cuales todavía no están presentes en la historia que se nos cuenta sobre ese momento histórico. Han tenido que ser trabajos como el de la constitucionalista Julia Sevilla, o documentos como la película «Las constituyentes» de Oliva Acosta, los que nos llamaran la atención sobre ese vacío permanente en los manuales, en los sesudos y numerosísimos libros escritos sobre aquella época o en los programas de nuestras Facultades. A pesar de su escaso número, las mujeres constituyentes tuvieron un papel decisivo en determinados debates y, lo más importante, demostraron con su práctica que el concepto de sororidad no es solo una 
ocurrencia, sino que también puede actuar como un compromiso efectivo. Ahí está como buen ejemplo su contestación frente a la norma discriminatoria que mantiene la preferencia del varón sobre la mujer en la sucesión a la Corona para demostrarlo. Lamentablemente ni representaron un número suficiente para convertirse en «masa crítica» ni tenían la autoridad que hubieran requerido para convertir en prioritarias determinadas cuestiones. No hay más que rastrear en los Diarios de Sesiones para encontrar sus voces y comprobar cómo sus intervenciones fueron escasas, además de que apenas ocuparon posiciones relevantes en la estructura parlamentaria. Las vindicaciones feministas apenas se oyeron en la Cámara: tal vez únicamente podamos recordar como tal la intervención de la diputada Revilla López en la Comisión, explicando el voto al artículo que sería el actual 14 de la Constitución. No podemos olvidar que las escasas mujeres constituyentes pertenecían a partidos que respondían a una cultura muy machista que era, a su vez, reflejo de una sociedad en la que las cuestiones esenciales no tenían que ver con la paridad, ni con el reconocimiento de derechos específicos de las mujeres.

El lenguaje usado por el constituyente es, sin ir más lejos, una buena demostración de que el poder originario, en 1978, fue esencialmente masculino, y de que las urgencias sociales y políticas poco tenían que ver con las desigualdades históricas de género. De alguna manera, el hilo que 1978 debería haber tomado de 1931 quedó en suspenso y el resultado fue un texto androcéntrico y nada permeable a las vindicaciones feministas.

3. ¿Cuáles cree que han sido los avances más reseñables en los últimos cuarenta años? ¿Cuáles considera que han sido los obstáculos más importantes y los objetivos no alcanzados?

\section{MARIA LUISA BALAGUER CALLEJÓN}

El estado Social y democrático de derecho definido en el art. 1.1 CE interesa y favorece a las mujeres. Las exigencias de libertad, igualdad, pluralismo y justicia constituyen presupuestos que universalizan a todas las personas, y por lo tanto a las personas que están socialmente en situaciones de inferioridad como ocurre con las mujeres. De ahí que los avances más reseñables en los últimos cuarenta años hayan venido de muchos espacios y sectores del conocimiento científico que desbordan el ámbito jurídico. En la filosofía, la construcción de la mujer como sujeto, ha permitido al derecho constitucional integrar a las mujeres como sujetos débiles constitucionales, cuya consecuencia sería la de justificar las acciones positivas de igualdad, o las desigualdades compensatorias recogidas en las leyes. En la biología, las aportaciones respecto de la inexistencia de desigualdades biológicas que justifiquen la desigualdad de capacidades entre mujeres y hombres 
derivadas de la naturaleza, permiten erradicar las discriminaciones laborales, o la historia, que ha contribuido a facilitar una arqueología de la mujer en términos de evolución de su situación en la sociedad. Junto a esto, el institucionismo y el asociacionismo han intervenido de manera muy positiva en el desarrollo de la igualdad. En lo que se refiere al primero, porque la creación de los Institutos de la Mujer y otras instituciones que fomentan su participación, permiten la salida de muchas mujeres a los espacios públicos, rompiendo las barreras más importantes para la igualdad que son la visibilidad y la independencia. Y el asociacionismo, además de facilitar estas dos circunstancias, permite organizar, estructurar y organizar las reivindicaciones y llevar a cabo acciones colectivas.

Si hemos de considerar el aspecto jurídico, sin duda ha sido la actividad legislativa de la Unión, la que ha tenido mayor importancia. Desde las Directivas de la Unión Europea, la Carta de los Derechos Fundamentales de la Unión, y algunos importantes documentos internacionales, hasta los más reducidos en sus posibilidades de aplicación como los Convenios Colectivos, Ordenanzas Municipales o Reglamentos de algunas instituciones locales.

Respecto de los obstáculos más importantes y los objetivos no alcanzados, también se haría necesario hacer algunas distinciones. Puede decirse que el nivel de concienciación de la desigualdad no está lo suficientemente asentado como para permitir la aceptación del movimiento feminista en cuanto al planteamiento de muchas de sus aspiraciones. A veces asuntos tan obvios como la necesidad de evitar la doble jornada en las mujeres, la necesidad de conciliación de la vida laboral y personal, la equiparación de los permisos parentales, se cuestionan justificando una desigualdad fáctica de dudosa legitimación. La igualdad impuesta en la Constitución y en las leyes debería hacer estéril toda discusión respecto de la equiparación de obligaciones con la descendencia en toda relación parental, y sin embargo, los tics estereotipados respecto de la carga familiar a las madres adquieren categoría de exclusión de una exigencia igualitaria. De esta forma, y con independencia de otros logros frustrados para la generalidad de las mujeres, la maternidad se erige como el mayor factor de exclusión de igualdad de las mujeres en la contratación laboral, y en cuanto la crianza le exige la permanencia en el hogar, en una discriminación en su libertad en relación con el padre.

La primera proclamación normativa de la igualdad entre las mujeres y los hombres se produce en la Constitución Española de 1978, que en su art. 14 reconoce el derecho a la igualdad, sin discriminación por razón de nacimiento, raza, sexo, religión, opinión o cualquier otra condición o circunstancia personal o social. En relación con el art. 9.2 CE, supone, un importante instrumento para activar la igualdad de la mujer, en un momento histórico en que claramente su incorporación a la sociedad, demandaba un respaldo normativo.

Pese a que el art. $14 \mathrm{CE}$ en los primeros momentos de vigencia constitucional fue objeto de algunas interpretaciones poco garantistas, y la jurisdicción ordinaria produjo algunas resoluciones judiciales en las que consideró su naturaleza programática, pronto el Tribunal Constitucional determinó tajantemente su 
normatividad de aplicación directa, como derecho fundamental directamente aplicable. Ciertamente, el art. 14 no figura exactamente dentro de la sección $1 .{ }^{a}$ del capítulo II de los derechos y libertades, pero igualmente se consideró que era frontispicio de ese capítulo, que se titulaba precisamente Derechos y Libertades.

El Tribunal Constitucional desde el primer momento, mantuvo una naturaleza normativa de la Constitución, y de aplicación directa de esos preceptos normativos, en una interpretación sistemática del art. 53 CE. Ciertamente, la idea de un proceso especial, preferente y sumario, junto a la exigencia de desarrollo legal y de respeto al contenido esencial de los derechos fundamentales en su conjunto, repercutió de manera muy precisa en la plena efectividad del derecho de igualdad.

Ahora bien, como se puso de manifiesto por P. Lucas Verdú, la aplicación del instituto de la prescripción al ejercicio de las acciones procesales minimizó los efectos de las posibilidades que se ofrecían a la reparación de las injusticias materiales creadas en las décadas anteriores, fundamentalmente en materia de derechos laborales. Debió entenderse sin duda como un derecho imprescriptible, porque no habrían sido tan numerosos los casos de las mujeres afectadas, y en cambio, el contenido de justicia material habría tenido mucha fuerza reparadora.

\section{PALOMA BIGLINO CAMPOS}

Gracias sobre todo a la acción del legislador, los avances en la igualdad entre hombres y mujeres alcanzados en los últimos años son, en mi opinión, destacadísimos y colocan a España en una posición mucho más avanzada de la que ocupan otros países con mayor tradición democrática, como son Italia, Francia o Alemania. No creo exagerado afirmar que, en España, la equiparación jurídica es total y que, en caso de que subsista algún tipo de discriminación, puede ser removida sin excesivos obstáculos.

Ahora bien, todavía queda mucho por hacer. Es preciso, en primer lugar, conseguir que la igualdad formal funcione de verdad en los ámbitos públicos, donde la mujer sigue sin desempeñar el papel que le corresponde. Son todavía muchas las instituciones, como es el Consejo General del Poder Judicial, el Tribunal Supremo o el Tribunal Constitucional donde la mujer no ocupa una posición igual a la de los varones. Y esta desigualdad no puede intentar justificarse, como ocurría hace unos años, por la ausencia de mujeres preparadas, sino que obedece, únicamente, a prácticas discriminatorias por parte de quienes tienen que hacer la selección de los cargos mencionados. En estos ámbitos, pues, no se trata de instaurar cuotas a favor de las mujeres, sino simplemente de tratarlas por igual que a los hombres, esto es, de no excluirlas en razón de su género.

La discriminación es todavía es mayor en los ámbitos privados: datos tan dispares como son la brecha salarial, las elevadas cifras de paro que afectan a las mujeres o su limitada presencia en los consejos de administración de las empresas demuestran que quedan muchas situaciones injustas por remover. 
La situación de desigualdad en que todavía nos hallamos se explica porque sigue existiendo una mentalidad profundamente discriminatoria en amplios sectores de la sociedad. En algunos casos, nos encontramos ante pequeños detalles que la opinión pública tolera. Son fenómenos de «micromachismo» (que van desde la imagen de la mujer que transmiten los medios, hasta chistes ofensivos para la dignidad de la mujer) que hay que combatir, no sólo porque transmiten, de por sí, una visión peyorativa, sino además porque constituyen el sustrato sobre el que se asientan conductas mucho más perniciosas, no sólo para la mujer sino para la sociedad entera.

El primer problema que considero necesario mencionar es el desigual reparto de tareas domésticas, que duplica la jornada laboral de la mujer y constituye una rémora en su avance profesional. Para las mujeres es imposible competir con los varones cuando corre a su cargo el doble de trabajo. El segundo, y el más grave de todos, es la violencia de género, cuya gravedad e intensidad superan las del terrorismo.

En otro lugar he señalado que estos problemas afectan directamente a las mujeres, pero que sería un gravísimo error considerar que sólo las conciernen a ellas. El descenso de natalidad, debido a las dificultades de conciliar la vida familiar y laboral, sacrifica la maternidad, pero también la paternidad. Desde un contexto más amplio, coloca a España en una difícil situación: según los últimos datos, la tasa de natalidad sólo había sido tan baja en 1941, en plena postguerra. La violencia sobre la mujer es, simple y llanamente, violencia y debe ser abordada por las fuerzas y cuerpos de seguridad del Estado con la misma contundencia con la que se combate cualquier atentado que ponga en riesgo la vida y la integridad de las personas.

Conseguir la igualdad supone aliviar a las mujeres de cargas que no le corresponden por la naturaleza de las cosas. La única diferencia biológica entre hombres y mujeres con relevancia para el ordenamiento es la maternidad. Todo lo demás, que va desde el cuidado del hogar al cuidado de los hijos y de los ancianos, no está en la naturaleza de las cosas, sino que puede ser desempeñado por personas de ambos sexos. Algunos de estos ámbitos interesan además a la sociedad entera, porque enlazan con la educación y la dependencia. Justo es, pues, que la sociedad garantice prestaciones de las que, hasta ahora, parece haberse desentendido.

\section{ÁNGELA FIGUERUELO BURRIEZA}

Es conveniente, después de cuarenta años de vigencia de la Constitución de 1978, hacer balance desde distintos enfoques de los puntos fuertes y de los más débiles de nuestra norma suprema; ley de leyes que ha permitido a España gozar del más largo período de democracia a lo largo de su historia. En el tema de la igualdad real y efectiva de mujeres y hombres, que es el monográfico de esta encuesta, se ha avanzado mucho pero no tanto como hubiera sido deseable. En las 
primeras décadas de la vigencia del texto constitucional los avances fueron más lentos y en gran medida se debieron a la labor realizada por los operadores públicos nacionales e internacionales. La labor de la Unión Europea, en cuanto organización supranacional de la que España forma parte desde el 1 de enero de 1986, a través del derecho originario y derivado y de la jurisprudencia del Tribunal de Luxemburgo, coadyuvó al avance en distintos ámbitos de las políticas públicas igualitarias en España. Sobre todo en el marco de las relaciones laborales y gracias al Tratado de Ámsterdam que reconoció la igualdad salarial de mujeres y hombres por un trabajo de igual valor. En esa labor pretoriana del Tribunal de Luxemburgo destacan también las acciones positivas en el ánimo de disminuir la brecha desigualitaria.

No podemos dejar a un lado la gran labor del Tribunal Constitucional Español que, en cuanto supremo intérprete constitucional, ha elaborado una ingente jurisprudencia (interpretando el art. 14 de la Constitución y el resto de los preceptos que reconocen el derecho a la igualdad) sólo superada por las sentencias que versan en torno al derecho a la tutela judicial efectiva reconocido en el art. 24 de la CE. También el legislador poco a poco iba poniendo sus pilares básicos sobre el tema pero no de forma muy decidida. Fue necesario llegar a los primeros años del presente siglo XXI para apreciar una clara voluntad en el legislador de apostar por avanzar con paso firme en la igualdad de mujeres y hombres en su vertiente material.

El Gobierno del Sr. Rodríguez Zapatero a partir del año 2004 sentó las bases para que desde el ámbito legislativo tuviésemos mimbres suficientes para intentar llegar a conseguir la igualdad real y efectiva de mujeres y hombres. Así, en diciembre del año 2004 se aprobó la Ley Integral contra la Violencia de Género que pretende prevenir y erradicar la violencia de género que es la lacra lacerante que pone en evidencia la persistente desigualdad de mujeres y hombres, siendo una de las cuestiones más graves de violación de derechos humanos. Es cierto que han disminuido las cifras de mujeres asesinadas a manos de sus parejas o exparejas pero no erradicamos la violencia de género; el fallo en mi opinión no está en las normas sino en la sociedad androcéntrica que aún persiste. Es preciso educar en igualdad desde la más tierna infancia e insistir desde todos los ámbitos con grandes dosis de pedagogía en la idea de que las mujeres no son propiedad de los hombres. En esa línea se aprobó el Pacto de Estado Contra la Violencia de Género en 2017, con una batería de más de doscientas medidas y que ha sido implementado por un Decreto-Ley en agosto de 2018. Me sigue preocupando el repunte de la violencia machista entre nuestros adolescentes y el tema de los neomachismos que debe ser atajado desde el ámbito de la educación.

La norma de mayor calado aprobada en esa legislatura fue la Ley Orgánica para la Igualdad efectiva de mujeres y hombres de 22 de marzo de 2007 (LOI). Esta norma nació con vocación de ser una ley-código de la igualdad, modificando unas veinte leyes de nuestro ordenamiento jurídico, y en cuyos contenidos se depositaron amplias expectativas de cambio que luego, pasada más de una década 
de vigencia, no han llegado a alcanzar en plenitud los logros que de ella se esperaban en un principio. La Exposición de Motivos de la LOI recoge el espíritu y el contenido de dicha norma. Así como el objeto y ámbito de la ley. De ello se deduce que la titularidad de derechos y deberes de las personas portadoras en igual medida de dignidad humana es indiscutible en el ámbito de un Estado de Derecho. Sin embargo, las mujeres han sufrido a lo largo de la historia grandes discriminaciones y algunas siguen persistiendo actualmente en la sociedad. El objetivo de la LOI pretende hacer efectivo el derecho de igualdad de trato y de oportunidades entre mujeres y hombres eliminando las discriminaciones en los ámbitos político, económico, social, cultural... para lograr una sociedad más democrática, justa y solidaria.

Lo que subyace en el fondo de la LOI es el deseo de lograr la igualdad material removiendo los obstáculos y los estereotipos sociales que dificultan su consecución. Esto exige políticas de acción y prevención de conductas antidiscriminatorias; el carácter transversal de la igualdad obliga a que la ordenación general de las políticas públicas se realice bajo la perspectiva de género en cuanto categoría analítica. Los criterios generales de actuación de los poderes públicos a dichos efectos se recogen en el art. 14 de la LOI y se repiten a lo largo de la ley aplicados a campos concretos de actuación en las distintas políticas públicas antidiscriminatorias; unos tienen carácter general y abstracto y otros inciden en políticas más concretas. Los de carácter abstracto han sido más fáciles de implementar porque se han quedado en declaraciones de principios en la letra de las normas y difíciles de evaluar en la práctica dado su carácter programático; pero, los de contenido concreto que requieren inversiones materiales han visto - debido en parte a la crisis económica - sus expectativas dejadas a un lado porque han carecido de las imprescindibles dotaciones presupuestarias.

En relación con lo antes dicho cabe aludir a la menor adopción de medidas necesarias para erradicar la violencia de género, el acoso sexual, el acoso por razón de sexo... o las medidas de acción positiva para atender a aquellos colectivos de mujeres en situaciones de especial vulnerabilidad: minorías, migrantes, niñas, discapaces, mujeres mayores, viudas... También la protección a la maternidad (embarazo, parto, lactancia) se vio modificada por la LOI que pretendió además, asegurar la conciliación de la vida laboral, personal y familiar de las mujeres y los hombres y la corresponsabilidad en las tareas domésticas. Se estableció un permiso de paternidad que actualmente está en 5 semanas pero no están asegurados los puestos de trabajo de las mujeres que decidieron ser madres. La crisis generalizada que duró largos años y aún persiste, a ciertos niveles, afectó en mayor medida al sector privado que al sector público donde había un margen algo más amplio de actuación.

En mi opinión uno de los puntos más débiles de la LOI es que está redactada en forma de recomendaciones; y éstas no tienen carácter preceptivo o vinculante. Únicamente la norma que está redactada en imperativo es la que hace referencia al tema de la composición equilibrada de las listas electorales. Ello significa que 
en cada lista electoral debe haber al menos el $40 \%$ de los miembros de un sexo y el $60 \%$ del otro (pero no se especifica cuál afecta a cada sexo en dicha horquilla). Ello ha permitido, a título de ejemplo, que en las elecciones generales del año 2016 el número de Diputados del Congreso se acerque al 40\% de los 350 miembros de la Cámara Baja.

A pesar de los avances señalados quedan brechas evidentes en el mundo del poder político, en el ámbito social, en los poderes económicos, en el mundo de la ciencia y de las artes, en los medios de comunicación, en las fuerzas armadas..., y persiste la brecha salarial entre mujeres y hombres que tal y como nos comentan los especialistas tardará años en ser erradicada. Debemos seguir luchando por lograr la igualdad real y efectiva.

\section{TERESA FREIXES SANJUAN}

La incorporación de España a Europa, al Consejo de Europa primero y a la Unión Europea posteriormente, ha sido decisiva para entender los avances en materia de igualdad. Primero porque la jurisprudencia de los tribunales europeos, Estrasburgo y Luxemburgo, ha tenido una gran influencia en todos los Estados miembros, España incluida. Y después por las regulaciones de la UE, en los Tratados, desde el Tratado de Ámsterdam, ampliando en forma notable las regulaciones de igualdad de mujeres y hombres y la no discriminación por razón de sexo u orientación sexual, reforzando la igualdad salarial y comprendiendo la igualdad en el trabajo, las acciones positivas y la transversalidad de la igualdad en todas las políticas, lo que conllevó la adopción de una batería ingente de normas de Derecho derivado, cuya transposición e implementación en los Estados ha sido muy importante.

\section{ITZIAR GÓMEZ FERNÁNDEZ}

Es evidente que han existido avances en absolutamente todas las áreas del derecho, pero quizá fuera didáctico explicar los avances normativos en torno a cuatro ejes:

i) en el primero están las normas que, en relación con el derecho civil y de familia, desarrollan el principio de igualdad entre los cónyuges que contempla el art. 32 CE. En este eje se citarían la Ley 30/1981, de 7 de julio, por la que se modifica la regulación del matrimonio en el Código Civil y se determina el procedimiento a seguir en las causas de nulidad, separación y divorcio; Ley 11/1981, de 13 de mayo, de modificación del Código Civil en materia de filiación, patria potestad y régimen económico del matrimonio; Ley 13/1983, de 24 de octubre, de Reforma del 
Código Civil en materia de tutela vendrá a superar la preferencia de los varones sobre las mujeres a la hora de designar tutores de menores o de personas incapacitadas; Ley 21/1987, de 11 de noviembre, por la que se modifican determinados artículos del Código Civil y de la Ley de Enjuiciamiento Civil en materia de adopción; Ley 11/1990, de 15 de octubre, sobre reforma del Código Civil en aplicación del principio de no discriminación por razón de sexo; Ley 15/2005, de 8 de julio, por la que se modifican el Código Civil y la Ley de Enjuiciamiento Civil en materia de separación y divorcio.

ii) en el segundo se identifican las disposiciones destinadas a garantizar el igual acceso, reconocimiento y desempeño de la mujer en el ámbito laboral. En particular la Ley 39/1999, de 5 de noviembre, para promover la conciliación de la vida familiar y laboral de las personas trabajadoras, posteriormente reemplazada por el Real Decreto Legislativo 2/2015, de 31 de octubre, que formula el actual texto de la Ley del Estatuto de los trabajadores (arts. 4.2.c, 14, 17, 23.2, 24, 28, 37, 45, 46, 48, 53 y 55) y la Ley del Estatuto Básico del Empleado Público (EBEP, arts. 14.i, 16.2, 37, 48, 49, 82 y 89), que en su versión vigente responde a la redacción dada por el Real Decreto Legislativo 5/22015, de 30 de octubre. A las disposiciones de estas dos normas se une lo dispuesto en la Ley Orgánica 3/2007, de 22 de marzo, para la Igualdad efectiva de mujeres y hombres (LOI) que contiene un apartado extenso relativo al derecho al trabajo en igualdad de oportunidades mediante la incorporación de medidas que buscan garantizar la igualdad entre sexos en el acceso al empleo, en la formación y en la promoción profesionales y en las condiciones de trabajo.

iii) en el tercer eje, asociado al desarrollo de la política punitiva del Estado, se agruparían tanto las medidas con impacto penal destinadas a garantizar la indemnidad de la mujer frente a situaciones de violencia machista, como la persecución por parte del Estado de conductas específicas en que se identifica un sujeto activo femenino, como lo es actualmente el aborto o lo fue en otro tiempo el adulterio. Cabe citar específicamente la tipificación de la violencia en el marco de relaciones afectivas presentes o pasadas y cualificando los hechos lesivos cuando se infringen sobre una mujer (arts. 148, 153, 171.4 y 172.2 CP, modificados por la Ley Orgánica 1/2004 de Medidas de Protección Integral contra la Violencia de Género), las agresiones o el acoso sexual que tienen por víctimas tanto a hombres como a mujeres — si bien estadísticamente estas sufren con mayor intensidad este tipo de delitos- (arts. 178 a 190 CP), la trata de seres humanos, que incluye la trata de mujeres y niñas para la explotación sexual o para la celebración de matrimonios forzosos (art. 177 bis), o la mutilación genital femenina (art. 149.2 CP, modificado por la Ley Orgánica 11/2003, de 29 de septiembre, de medidas concretas en materia de seguridad ciudadana, violencia doméstica e integración social de 
los extranjeros). Tampoco puede olvidarse la regulación del derecho al aborto que hoy se contiene en la LO 2/2010, de 3 de marzo, de salud sexual y reproductiva y de la interrupción voluntaria del embarazo, pendiente de juicio abstracto de constitucionalidad por parte del Tribunal Constitucional.

iv) y, por último, el cuarto eje haría referencia a las disposiciones normativas tendentes a garantizar el derecho de acceso de las mujeres, en condiciones de igualdad con los hombres, a las funciones y cargos públicos que prevé el art. 23.2 CE.Debe citarse, en este caso, la modificación de la Ley Orgánica de Régimen Electoral General (LOREG) por la Ley Orgánica de Igualdad que introdujo cambios en los arts. 187.2, 201.3 LOREG y en su disposición adicional 1.2, añadiendo además un art. 44 bis y una disposición transitoria 7. .

También han cambiado las instituciones, desde la creación del Instituto de la mujer en el año 1983 y la elaboración de los primeros planes de igualdad en el año 1987, hitos seguidos de cerca por las Comunidades Autónomas que replicaron tanto los organismos dedicados a la institucionalización de las políticas de igualdad, como la planificación de esas políticas públicas. Lamentablemente la crisis económica incidió negativamente el ese desarrollo institucional. Baste un ejemplo para dar cuenta de ello: en el año 2008, se creó el Ministerio de Igualdad de España, creado para impulsar las políticas recogidas en la Ley para la Igualdad y en la Ley Integral contra la Violencia sobre la Mujer, que desapareció como Ministerio autónomo a finales del año 2010 para pasar a reintegrarse, por razones de eficiencia económica en el Ministerio de Sanidad, Política Social e Igualdad. Idéntica razón inspiraría a la Ley 15/2014, de 16 de septiembre, de racionalización del Sector Público y otras medidas de reforma administrativa, que transformó el Instituto de la Mujer en el Instituto de la Mujer y para la Igualdad de Oportunidades, haciéndole perder, de este modo, la singularidad como institución específica para la promoción de la igualdad de género.

Indudablemente la faz de la presencia femenina en los puestos de toma de decisiones, tampoco es la misma en 2018 que en 1978. No es este el lugar para aturdir con datos estadísticos, pero un ejemplo puede ser ilustrativo: en el Congreso de los Diputados la presencia femenina ha subido del $5.14 \%$ de la primera legislatura tras la constituyente, al 39,43\% en la XII. ${ }^{a}$ legislatura, sin haberse alcanzado nunca la paridad total. Como contrapunto al dato, sin duda positivo, hay que decir que desde la IX. ${ }^{a}$ legislatura, que es la primera en que se aplica la reforma de la LOREG, el incremento es de apenas cuatro puntos porcentuales, de modo que puede concluirse que se incrementó en mayor medida la presencia femenina en la Cámara Baja sin soporte normativo que con él, lo que debería llevarnos a una necesaria revisión de las causas y del modelo de parificación escogido. La misma reflexión crítica debe formularse en relación con la presencia de mujeres en la cúpula del Poder Judicial (Presidencias de Tribunales Superiores de 
Justicia, Tribunal Supremo, Tribunal Constitucional); o en los equipos directivos de las grandes empresas del sector privado.

En suma, creo que el balance es muy positivo, si además sumamos a la ecuación la concienciación creciente en materia de igualdad entre hombres y mujeres, que se ha traducido en el último año en un repunte del movimiento feminista y en una movilización sin precedentes en la historia reciente de nuestro país. No creo que pueda negarse que España es uno de los mejores países del mundo para vivir, si se es mujer. El Georgetown Institute for Women, Peace and Security, junto con el Peace Research Institute of Oslo, publican el WPS Index (Women, Peace and Security index), un estudio que formula un ranking de países en virtud de diversas variables que permiten identificar los países en que, independientemente del nivel de desarrollo económico, es mejor ser mujer en términos de paz, justicia, seguridad e inclusión. Según este ranking España se sitúa en el 5. ${ }^{\circ}$ puesto de 156 países analizados, por detrás de Islandia, Noruega, Suiza y Eslovenia.

No obstante, y desde esa posición optimista, a mi juicio, queda mucho por hacer en materia de presencia de las mujeres en los puestos de toma de decisiones, tanto en el espacio público, como en el espacio privado. Una presencia necesaria pero no suficiente, porque entiendo que es un presupuesto imprescindible para cambiar sucesivamente las formas de trabajar, gestionar lo público y tomar decisiones, pero solo un presupuesto. La conciliación de la vida personal y familiar con la vida profesional sigue planteando una serie de paradojas irresolubles, particularmente para las mujeres, y la adecuada coordinación entre la esfera de la vida pública y de la vida privada de las personas pasa por modificar la forma en que unos y otras abordamos nuestra presencia en cada una de esas dos esferas. Creo que sigue siendo un problema esencial el de la violencia de género, en todas sus modalidades pero particularmente en la que se manifiesta en forma de violencia sexual, y de violencia en el marco de las relaciones afectivas o familiares. También considero imprescindible actuar sobre la educación obligatoria, trabajar la coeducación y la educación en valores cívicos e igualitarios, revisando el alcance del art. 27 CE y la traducción que de él ha hecho la actual Ley Orgánica de Educación en la redacción que le dio la LOMCE (LO 2/2006, de educación y LO 8/2013, de 9 de diciembre, para la mejora de la calidad educativa).

\section{FERNANDO REY MARTÍNEZ}

Nada hacía suponer en 1978 que la cuestión de la igualdad jurídica y real entre mujeres y hombres se iba a convertir cuarenta años después en uno de los temas constitucionales centrales. En el fundamental, incluso, para el influyente feminismo académico. Tanto como para sustituir como enfoque ideológico/metodológico par excellence a otros criterios que en el pasado (y hoy de forma más residual) cumplieron funciones parecidas, como el religioso, el marxista, etc. Pero, en 1978, en la agenda de la igualdad de género estaban cosas diferentes que en la 
actual. Entonces, sobre todo, el divorcio, aún no reconocido, y, en menor medida, el aborto. Hoy, la lucha contra la violencia de género en todas sus formas y la plena igualdad ciudadana entre mujeres y hombres, lo que afecta a ámbitos tan cruciales como el empleo y la educación.

Los cambios sucedidos en estos cuarenta años han sido radicales. Y no sólo respecto de la situación episódica del franquismo, sino de toda la historia. La autonomía personal, social, económica y cultural de las mujeres nunca antes había sido tan plena. Tampoco la consciencia de ello. Esto marca un antes y un después histórico que hemos podido observar (e, incluso, participar, de alguna manera) las personas que hemos vivido en las postrimerías del siglo $\mathrm{xx}$ y el comienzo del XXI.

La igualdad real entre mujeres y hombres comienza, a mi juicio, sobre todo, con la autonomía económica de las mujeres respecto del varón, es decir, con el trabajo extradoméstico. La irrupción masiva de las mujeres en el mercado de trabajo es el nuevo factor social que cambia radicalmente el estado de cosas tradicional. Por supuesto, los prejuicios sexistas se resisten a desaparecer; de hecho, en este campo hay avances, pero también retrocesos: la igualdad no cae como fruta madura, es una conquista diaria de la civilización. En el ámbito laboral se mantienen fenómenos obstinados: el menor salario por trabajos de igual valor, la segregación horizontal y vertical, el acoso laboral y el acoso de género, etc. En conjunto, las mujeres siguen ocupando en todo el mundo el trabajo de peor calidad y más precario. Esto se debe porque muchas personas siguen pensando, a pesar de todo e incluso a veces de manera poco consciente, que deben ser las mujeres quienes deben ocuparse exclusiva o preferentemente del cuidado de los hijos y de los padres. Tanto trabajo doméstico como sea posible, tanto trabajo extradoméstico como sea indispensable. Esto no es igualdad, que requiere un intercambio potencial de papeles sociales entre mujeres y hombres. Para que las mujeres entren de verdad en el espacio extradoméstico, los hombres debemos entrar de verdad en el espacio doméstico. La cuestión de la conciliación entre vida privada y laboral se convierte, así, a mi juicio, en la cuestión capital de nuestros días. Normalmente, el enfoque normativo tiende a facilitar dicha conciliación a costa de fragilizar la carrera profesional de quienes la eligen; como abrumadoramente son las mujeres, tales medidas de conciliación lo que hacen es consagrar aún más la desigualdad entre mujeres y hombres. La legislación sobre conciliación es, en líneas generales, una legislación bumerán que consigue justo lo contrario de lo que pretende.

El otro campo principal de preocupación es el de la violencia en todas sus formas. Se ha avanzado mucho, pero los datos son brutales. En 2017, 51 mujeres asesinadas por sus parejas o exparejas y 166.760 denuncias por violencia de género. La cifra negra seguro que es mayor.

Espacios también sensibles para lograr la igualdad real son el de la imagen social de las mujeres y los medios de comunicación, donde, a pesar de los innegables avances, también se siguen produciendo abusos y retrocesos (me inquietan, 
especialmente, algunos programas de tipo terrario humano, de gran éxito, además, donde se transmite una imagen estereotipada de las mujeres, así como algunas letras de canciones pop); el campo de la educación, en el que la ciencia y la tecnología sigue siendo predominantemente masculinas; el del poder y la toma de decisiones, aun fuertemente desequilibrada a favor de los varones en todos los ámbitos, públicos y no digamos ya privados (creo que no es ajeno a ello el problema capital no resuelto, antes mencionado, de la conciliación entre vida profesional y vida privada); y, finalmente (aunque la lista podría ser mayor), la situación de ciertos colectivos concretos de mujeres, desde las reclusas, a las mujeres en prostitución, etc. Porque la discriminación de las mujeres es la más antigua en el tiempo, la más extendida en el espacio, la que más forma reviste (desde la violencia más cruda hasta el paternalismo refinado que dice tratar a las mujeres mejor, pero porque las considera que pueden o valen menos) y la más básica o primaria porque siempre se añade al resto de discriminaciones provocando formas específicas y más agravadas de subordinación. A esto último se llama discriminación múltiple o interseccional. Un grupo social donde es particularmente apreciable este tipo de discriminación es el de las mujeres de minorías étnicas (gitanas, inmigrantes). Están sometidas a la discriminación que sufre su etnia y también por los varones de su propio grupo, normalmente en nombre de los valores tradicionales y familiares.

\section{OCTAVIO SALAZAR BENÍTEZ}

Los avances más significativos han tenido que ver con la progresiva consolidación, al menos a nivel formal, de lo que podemos considerar ciudadanía de las mujeres. Ese proceso, como bien explica María Luisa Balaguer, se ha ido articulando a través de cuatro ejes: el Derecho civil y de familia; la igualdad en el ámbito laboral; la política punitiva del Estado y el acceso a las funciones y cargos públicos. Ahora bien, ese horizonte de la plena ciudadanía no se traduce jurídicamente de manera estricta hasta que la LO 3/2007, de 22 de marzo, para la igualdad efectiva de mujeres y hombres, proclama en su artículo 1..$^{\circ}$ que «Las mujeres y los hombres son iguales en dignidad humana, e iguales en derechos y deberes». Es decir, el reconocimiento legal de la igualdad de género no se produce realmente hasta iniciado el siglo XXI, cuando son aprobadas dos leyes que pueden considerarse las dos piezas esenciales en esta materia: la ya citada Ley de igualdad y, con carácter previo, la, recordemos, aprobada por unanimidad de todos los grupos políticos, LO 1/2004, de 28 de diciembre, de medidas de protección integral contra la violencia de género. Ello no quiere decir que con anterioridad no se fueran realizando conquistas jurídicas, pero no es hasta las fechas señaladas cuando disponemos, a nivel estatal, de un cuerpo normativo en el que las mujeres aparecen como sujetos de derechos. En esta línea, no podemos olvidar que fue ya en pleno siglo XXI cuando se llegaron a aprobar leyes tan decisivas para la ciudadanía 
de las mujeres como la LO 2/2010, de 3 de marzo, de salud sexual y reproductiva y de la interrupción voluntaria del embarazo, o la Ley 14/2006, de 26 de mayo, sobre técnicas de reproducción humana asistida.

En las décadas anteriores, confluyeron distintos procesos que fueron removiendo los obstáculos heredados y, de alguna manera, preparando el terreno para que las leyes reconocieran el derecho a la igualdad efectiva de mujeres y hombres. De entrada, y como he apuntado con anterioridad, fueron esenciales todas las reformas que de manera muy temprana se hicieron en materia de Derecho Civil. En el desarrollo de, sobre todo, políticas de igualdad de oportunidades, jugó un papel esencial lo que se ha llamado «feminismo institucional», muy especialmente desde la creación en 1983 del Instituto de la Mujer. Por supuesto, fue decisiva la incorporación a la Unión Europea y la incidencia del Derecho Comunitario. En este sentido no hay que olvidar que la aprobación de la CE y los primeros años de nuestra democracia coinciden con un momento crucial desde el punto de vista del reconocimiento internacional de los derechos de las mujeres. Recordemos que 1975 fue declarado por Naciones Unidas Año Internacional de la Mujer, o cómo las diferentes cumbres internacionales celebradas desde los años 80 fueron generando no solo una conciencia global sino también aportando conceptos y herramientas que en esta materia han acabado por consolidarse. Junto a todos los elementos anteriores, sería injusto no valorar la labor llevada a cabo en el ámbito autonómico, ya que en algunas Comunidades Autónomas se desarrollaron políticas, por ejemplo, legislativas, que pondrían las bases para la posterior tarea estatal. No hay que olvidar que Estatutos de autonomía como el andaluz, tras su reforma de 2007, van mucho más allá que la misma Constitución, ya que incluso se plantea de manera expresa el objetivo de conseguir una democracia paritaria (art. 10.2).

Todos estos instrumentos, así como las políticas que, de manera irregular, y no siempre con la debida coordinación, se han ido desarrollando en los distintos niveles territoriales, han permitido: $\left.10^{\circ}\right)$ Romper con las estructuras jurídicas heredadas de un sistema patriarcal y machista; $\left.2 .^{\circ}\right)$ Poner las bases para la negociación de un nuevo «pacto social» entre mujeres y hombres. Y, digo bien, poner las bases, ya que todavía estamos lejos de lo que podríamos calificar como democracia paritaria y de lo que podría entender como nueva dogmática de la igualdad de mujeres y hombres. Vivimos en una sociedad «formalmente igual», usando la terminología de Catherine Mackinnon, pero todavía estamos lejos de la igualdad real y efectiva que sería la propia de una «sociedad democrática avanzada». Y ello porque, en gran medida, seguimos manejando un concepto de ciudadanía apoyado en un modelo humano parcial, es decir, en el modelo que convierte lo masculino en universal. El poder y la ciudadanía, los dos grandes ejes de un sistema constitucional, continúan teniendo rostro masculino.

El gran reto del siglo XxI entiendo que ha de ser dar el salto cualitativo de las políticas dirigidas a prevenir o paliar las consecuencias de un sistema sexo/género que subordina a las mujeres a la adopción de estrategias que permiten superar 
o remover dicho sistema. Es decir, no se trataría solo de incorporar a las mujeres al pacto sino de hacerlo de acuerdo con otras condiciones, métodos y palabras. En este salto cualitativo sería esencial asumir de una vez por todas que constitucionalismo y feminismo comparten una misma genealogía emancipadora.

La no consolidación de lo que sería, desde mi punto de vista, un nuevo marco jurídico-constitucional de la igualdad de género ha provocado, por ejemplo, que los efectos de la reciente crisis económica hayan sido especialmente negativos en este ámbito. Así lo puso de manifiesto el Informe que el Comité de Naciones Unidas sobre la Eliminación de la Discriminación contra las Mujeres hizo público el 24 de julio de 2015. En dicho Informe, aunque se reconocían los esfuerzos hechos por el legislador español en la implementación de la Convención para la Eliminación de todas las formas de Discriminación contra la Mujer de 1979 (CEDAW), se subrayaba como la crisis económica y financiera y las medidas de austeridad adoptadas desde 2008 habían tenido efectos negativos en todas las esferas de la vida de las mujeres. El Comité de Naciones Unidas insistía que precisamente en una época de crisis económica y de restricciones fiscales es cuando son más necesarios especiales esfuerzos para garantizar los derechos de las mujeres, dando prioridad a aquéllas que se encuentran en situaciones de mayor vulnerabilidad. Un objetivo que, lamentablemente, no ha sido prioritario en unos años en los que ha pesado más la «estabilidad presupuestaria» que la efectiva garantía de los derechos humanos, tal y como reiteradamente han subrayado los informes realizados por la denominada Plataforma Sombra de la CEDAW (https://cedawsombraesp.wordpress.com/category/informes-sombra/) El informe negativo del Comité de Naciones Unidas vendrían a demostrarnos dos cuestiones interrelacionadas: $\left.1 .^{a}\right)$ Las debilidades de buena parte de las políticas de igualdad adoptadas en España, muy singularmente de los instrumentos legislativos; 2. ${ }^{a}$ ) La supervivencia de unos patrones sociales, políticos, jurídicos, económicos y culturales que continúan prorrogando un orden patriarcal. Por otra parte, no podemos olvidar que el modelo de Estado social implantado en nuestro país, de marcado carácter «familiarista», no ha contribuido a remover unas estructuras que han seguido manteniendo cautivas a las mujeres de los trabajos domésticos y de cuidado. En este sentido, no queda más remedio que recordar la Ley 39/2006, de 14 de diciembre, de Promoción de la Autonomía Personal y Atención a las personas en situación de dependencia, como una oportunidad perdida. La consecuencia terrible de todo ello ha sido que la mayoría de las mujeres españolas no han logrado superar el que el feminismo ha denominado «dilema de Mary Wollstonecraft».

Sin duda, y gracias a la incidencia del Derecho internacional en general y del Derecho comunitario en particular, nuestro ordenamiento ha ido incorporando conceptos y herramientas decisivas en la lucha contra la desigualdad de género. Ahora bien, es cierto que no en todos los casos su aplicación ha sido efectiva. Baste con recordar la incorporación del denominado mainstreaming de género, insuficientemente traducido en nuestro ordenamiento como transversalidad. En la mayoría de las ocasiones su introducción no ha pasado de ser meramente retórica. 
Por otra parte, tampoco existe un consenso acerca de qué sea dicho principio y de cómo aplicarlo, a pesar de que el punto IV de la Plataforma de acción aprobada en la IV Conferencia Mundial sobre la Mujer celebrada en Beijing en 1995 lo concretó en la promoción de «una política activa y visible que eleve a corriente principal la perspectiva de género en todas las políticas y programas». Ello obliga a que el género como herramienta analítica esté presente en todas las fases de desarrollo de dichas políticas — diseño, ejecución, evaluación-y a que en todas ellas intervengan actores y actrices con la debida formación en la materia. Y todo ese proceso debe entenderse como parte esencial, y obligatoria, no como una mera recomendación en manos de la voluntad política. Es decir, estamos ante no solo un enfoque sino también ante una auténtica estrategia que, en el sentido más estrictamente constitucional, hemos de entender conectada a la efectividad de la igualdad material.

Sin embargo, el análisis de la aplicación del mainstreaming de género por los poderes públicos españoles demuestra que, en la mayoría de las ocasiones, la misma se ha limitado a su dimensión formal o procedimental, sin avanzar en la dimensión sustantiva. No ha supuesto un cambio sustancial en la manera de hacer las leyes, o en la forma de diseñar y/o evaluar las políticas públicas. Baste con recordar la eficacia tan limitada que ha tenido en la práctica la obligatoriedad de los informes de impacto de género en los proyectos legislativos y planes del gobierno, introducida en 2003 y ampliada por la LO 3/2007.

Por otra parte, la continuidad del sistema sexo/género ha sido posible gracias al predominio de un Derecho antidiscriminatorio construido sobre dos paradigmas liberales (patriarcales) que urge superar: $1 .^{\circ}$ ) El sujeto masculino como paradigma del sujeto de Derecho; $2^{\circ}$ ) La actuación sobre el sujeto individual que discrimina y no sobre las causas sociales, políticas, económicas y culturales que generan la desigualdad de género. Es decir, de manera general, al abordar la situación de las mujeres, no se ha partido de la toma en consideración de la discriminación estructural, de tipo sistémico, que sufren. Y deberíamos tener aprendida la lección de que una discriminación sistémica no se resuelve reequilibrando el poder sino revolucionándolo. La superación de estos obstáculos no pueden basarse lógicamente solo en reformas jurídicas —el Derecho, aun con perspectiva de género, tiene una eficacia limitada-, sino a través de acciones políticas que permitan reformar las estructuras de poder. Desde este punto de vista el eje de actuación preferente debería situarse en el triángulo políticas socioeconómicas/ educativas/culturales. Una opción que llevaría a invertir la tradicional ordenación jerárquica de las clásicas declaraciones de derechos.

Finalmente, no deberíamos olvidar que aún debemos seguir trabajando por conseguir una presencia paritaria de mujeres y hombres en la toma de decisiones y en todas las instancias de poder. Un objetivo para cuya efectividad son necesarias acciones positivas que obliguen a transformar la composición mayoritariamente masculina de los poderes. Se trata de hacer efectivo el derecho a participar en los asuntos públicos (art. $23 \mathrm{CE}$ ) en condiciones de igualdad (art. 9.2 CE), de 
tal manera que mujeres y hombres seamos finalmente equivalentes en el ejercicio de la ciudadanía. Entiendo además que la mayor presencia de mujeres en las instituciones, tal y como lo demuestra la práctica internacional, permitiría desarrollar políticas centradas en cuestiones que, de no estar ellas, continuarían en un lugar muy secundario de la «agenda».

4. Se han realizado muchas propuestas sobre la conveniencia de reformar la Constitución desde el punto de vista de la igualdad de hombres y mujeres ¿Qué opinión tiene al respecto?

\section{MARIA LUISA BALAGUER CALLEJÓN}

Con carácter previo, hay que plantear la necesidad, cada vez más evidente, de reformar la Constitución Española de 1978. La sola razón del cambio del tiempo, en una sociedad altamente tecnificada y cambiante, como la actual, produce unos desajustes inevitables en el derecho, y en el caso de las normas constitucionales, estos efectos se acentúan por tratarse de normas fundamentales, que condicionan el resto del ordenamiento jurídico. A esto han de añadirse factores históricos específicos, como el hecho de que la constitución vigente se aprobara en España antes de formar parte de la Unión Europea, y el desarrollo del derecho autonómico, en un plano evolutivo que no responde a la posición original pensada por el constituyente. Es cierto que la existencia en la Constitución de instituciones como el Tribunal Constitucional han permitido la actualización de su texto en términos que podrían ser calificados de muy positivos, pero los límites de la actividad interpretativa no permiten la creación del derecho en situaciones ni siquiera previstas en el momento de su aprobación. Hoy la sociedad española ha cambiado con respecto a la 1978, hasta el punto de que algunos de los derechos reconocidos en el Título I de la Constitución han quedado obsoletos, y han emergidos otros que exigen la consideración del legislador. En este enclave ha de situarse la respuesta acerca de la necesidad de un cambio constitucional desde el punto de vista del género.

Desde el lenguaje comprensivo de la identificación de las mujeres y los hombres, hasta la revisión de un sistema monárquico en línea sucesoria del varón, han de ser puestos en cuestión en una sociedad que ha integrado los derechos de las mujeres en condiciones de igualdad, y avanza hasta la igualdad real entre mujeres y hombres. Pero no se trata solamente de una corrección formal o institucional, sino sobre todo de considerar a la luz de la sociedad del siglo XXI como debe regularse en una constitución la igualdad de género. La integración de la perspectiva de género en el derecho, como exigencia de la igualdad material, debe ser trasladada a la Norma Fundamental, si se quiere entender que la igualdad de género es una exigencia de justicia. La reforma de 
la Constitución es necesaria por exigencias del cambio social habido desde 1978 hasta ahora, pero una de esas exigencias, más allá de la distribución territorial del Estado, o la necesidad de integrar el derecho de la Unión, está la de abordar la reforma constitucional con perspectiva de género.

Dicho esto, el contenido constitucional de la reforma en relación con los derechos de las mujeres debe tener en cuenta las diferencias entre mujeres y hombres, en orden a determinar sus derechos, en cuánto al único factor biológicamente condicionado. Así, el derecho de las mujeres a no sufrir injerencias en su cuerpo, a no sufrir violencia de género, a su propio cuerpo, y otros derivados de esta situación, deben ser constitucionalizados para evitar que puedan estar en función de las mayorías derechos tan íntimamente relacionados con su dignidad. Además de eso, es importante considerar los problemas específicos de género que puedan tener rango constitucional, como el del derecho a una vida en paz, en relación con la violencia de género. La Constitución ha de considerar esa situación con el nivel normativo exigido, para contribuir desde el texto fundamental del ordenamiento a una clara conciencia de la necesidad de hacer desaparecer ese problema.

\section{PALOMA BIGLINO CAMPOS}

Vaya por delante que, muy a mi pesar, me parece altamente improbable que la Constitución llegue a reformarse, al menos a corto plazo. Creo, además, que la situación de la mujer puede mejorar sin necesidad de reformar la Norma fundamental. Pero, en caso de que la modificación de la Constitución pudiera prosperar, es evidente que sería preciso suprimir la preferencia del varón sobre la mujer en la sucesión a la Corona, asunto al que he hecho referencia antes. Es cierto que sería una reforma de procedimiento agravado y que afectaría directamente sólo a las herederas al trono, en caso de que hubiera algún varón en situación de suceder. Ahora bien, la discriminación actual transmite una valoración de la mujer que está fuera de los tiempos y resulta inaceptable, porque no hay razones que expliquen que el varón, sólo por su sexo, sea preferible a la mujer.

También me parecería conveniente modificar el art. 6 CE para imponer a los partidos políticos un compromiso más activo con la igualdad entre hombres y mujeres en su funcionamiento interno. Es cierto que la L.O. 2/2011 introdujo, como nuevo art. 44.bis de la LOREG, las listas electorales de composición equilibrada, medida que vincula a los partidos en la presentación de candidatos, esto es, en su funcionamiento externo. Ahora bien, esta obligación no alcanza a los cargos y órganos directivos de los partidos. Por ello, no estaría de más que el art. 6 de la Constitución recogiera, al igual que ha hecho el art. 4 de la Constitución francesa, la especial vinculación que el principio de igualdad efectiva impone a los partidos políticos y su deber de favorecer el igual acceso de hombres y mujeres a los cargos políticos de libre designación y a los cargos de carácter representativos. 
No soy partidaria de modificar la definición de Estado social y democrático de Derecho que aparece en art. 1.1 de la Constitución para añadir el término paritario. La expresión «democracia paritaria» nunca me ha parecido satisfactoria, porque la historia demuestra que es mejor no añadir adjetivos al término democracia. Tampoco me parece fácil corregir el lenguaje de la Constitución. No digo que no pueda mejorarse, pero las soluciones que por ahora se han barajado parecen tener más inconvenientesque ventajas.

Hasta hace poco no consideraba necesario elevar las medidas de acción positiva a rango constitucional. Me parecía que ese tipo de medidas eran convenientes, y en algunos casos imprescindibles, en niveles normativos inferiores porque, como señalaba antes, no se puede tolerar que determinadas formas de discriminación sigan subsistiendo. Si la mujer no ha estado en muchos ámbitos de toma de decisiones, públicos y privados, por su género, ¿por qué no admitir que ahora lo esté en virtud de su género? Ahora bien, pensaba que estos instrumentos tienen carácter temporal, por estar destinadas a situar a las mujeres en la misma posición que los hombres.

Sigo considerando que no hay diferencias entre ambos sexos en mérito o capacidad. Si las mujeres continúan excluidas de determinados ámbitos no es, pues, porque se encuentre en una situación de inferioridad, sino sólo porque hay discriminaciones que subsisten. Las cuotas pueden servir para removerlas lo antes posible, pero deben ser consideradas medidas excepcionales, porque parten de una visión que perjudica a las mujeres. Su punto de partida es que ciertos sectores, sobre todo en la toma de decisiones, pertenecen por derecho natural a los hombres, por lo que se limitan a reservar un ámbito limitado a las mujeres, que parecen jugar en campo ajeno. La solución a la desigualdad no está, pues, en cerrar parcelas sólo para mujeres sino, simplemente, en tratarlas como iguales. Mientras no se produzca esta igualdad de trato, no sólo se incumple el mandato del art. 9.2 CE sino, más propiamente, el propio art. $14 \mathrm{CE}$, lo que supone una vulneración de la Constitución todavía más grave.

He mantenido, además, que no parecía conveniente introducir porcentajes en la Constitución porque, aunque a corto plazo puedan ser una garantía de la presencia de la mujer en ciertas instituciones, nada asegura que, con el tiempo, puedan constituir un límite. Aunque la cuota fuera del cincuenta por ciento, podría llegar a ser contraria al interés de las mujeres si, en determinados ámbitos, estas demuestran tener más mérito y capacidad que los varones.

Ahora bien, el panorama político está cambiando muy rápidamente, no sólo en España sino en otros países occidentales, donde la «revolución conservadora» propugna nuevas formas de machismo y discriminación. Si el rumbo sigue siendo este, introducir las medidas de acción positiva en la Constitución comienza a ser imprescindible. Como antes señalaba, hay que dejar claro que poner en cuestión lo que ha costado tantos siglos conseguir es, también, enfrentarse a la Norma fundamental. Llevar a la Constitución las listas de composición equilibrada, la obligación de que determinadas instituciones sean paritarias o las medidas para 
luchar contra la violencia de género no era preciso cuando este tipo de medidas recibían el respaldo de casi todos los partidos políticos. Ahora, sin embargo, comienza a ser necesario sustraer estos avances a la libre configuración del legislador, porque la experiencia demuestra que pueden ser objeto de negociación y, por lo tanto, sufrir erosiones que hace poco resultaban inimaginables.

\section{ÁNGELA FIGUERUELO BURRIEZA}

Sobre el tema de la reforma de la Constitución Española han corrido ríos de tinta en los últimos años, pues se trata de uno de los temas sobre los que más se habla y sobre los que menos se actúa. La composición del Parlamento Español en la XII legislatura hace casi imposible - por el tema de las mayorías que requiere el procedimiento - pensar que pueda llevarse a cabo. Pero ello no impide que teoricemos sobre el tema; y eso es lo que han hecho obras abundantes y voluminosas que han visto la luz recientemente.

Es evidente que después de 40 años de vigencia de la norma fundamental de 1978 cualquier reforma constitucional de gran calado requiere un nuevo pacto de Estado. En el año 78 la Constitución fue redactada por hombres y para hombres. Las 27 mujeres parlamentarias presentes en las Cámaras hicieron lo que pudieron, pero sus fuerzas eran escasas. En la norma vigente, redactada en masculino genérico, brilla por su ausencia la perspectiva de género; cualquier revisión constitucional, teniendo en cuenta los avances en todos los campos conseguidos por el movimiento feminista a lo largo de estas cuatro décadas, requiere revisar el texto en su totalidad y redactarlo con un lenguaje no sexista donde se elimine el masculino genérico en cuanto sexo no marcado. Como lo que se nombra no existe es preciso resaltar en femenino los derechos de las mujeres titulares de los mismos en idéntico grado que los hombres. La introducción de la perspectiva de género en la norma suprema obligará a la introducción de nuevos derechos como el derecho a una vida sin violencia de género, los derechos a las diferentes identidades sexuales, los derechos sexuales y reproductivos, los derechos a la conciliación de la vida personal y laboral... derechos todos ellos reconocidos a nivel internacional y comunitario, en la jurisprudencia nacional e internacional de los Tribunales de Luxemburgo y Estrasburgo.

El carácter transversal de la igualdad en cuanto valor, principio jurídico y derecho subjetivo impregna todo el texto constitucional y afecta en mayor medida a la parte dogmática de la Constitución. No olvidemos que ampliando los contenidos de los arts. 14 y 9.2 de la CE implementamos los postulados del Estado social y democrático de Derecho. Ello implica apostar por un nuevo pacto de convivencia ampliando no sólo el contenido sino también las garantías de los derechos y libertades ante la desconfianza que ha suscitado la crisis generalizada que hemos sufrido y que ha ocasionado grandes brechas de desigualdad; todo lo cual obliga a pensar seriamente en incrementar las garantías de los derechos sociales 
(que son los que proporcionan la igualdad material a la ciudadanía). De ahí que, algunos derechos actualmente considerados en el ámbito de la categoría de derechos sociales deben obtener el rango de fundamentales, como sucede con el derecho a la protección de la salud (en el cual es preciso introducir la perspectiva de género), la protección por la Seguridad Social, el reconocimiento de un ingreso mínimo vital para el mantenimiento de una vida digna, mejorar el reconocimiento del derecho al trabajo (eliminando la brecha salarial que sufren las mujeres) y sus garantías jurisdiccionales; también la protección a las familias en el sentido más amplio del término y regular a nivel constitucional el derecho a la conciliación de la vida familiar y laboral. Conviene dotar también de contenido efectivo el derecho a la vivienda con obligaciones para los poderes públicos, sobre todo en casos de desahucio, siendo imprescindible reforzar el derecho a la educación y al medio ambiente saludable. (Todos ellos derechos que inciden indudablemente en mayores dosis igualitarias entre mujeres y hombres).

Incluso, para revitalizar el Estado de derecho en pro de una igualdad real y efectiva de mujeres y hombres hay que repensar el Catálogo de derechos fundamentales, reordenándolo en algunas ocasiones y en otras incorporando nuevos derechos que no existían en el momento constituyente y que ahora son de obligado reconocimiento atendiendo a nuestra condición de Estado Miembro del Consejo de Europa y de la Unión Europea. Por ello el derecho a la igualdad se debe predicar de todas las personas y ampliar su contenido a todos los temas incluyendo nuevas causas de prohibición de la discriminación; entre ellas hay que eliminar la preferencia del varón sobre la mujer en la sucesión a la Corona, reconocer los derechos vinculados a la bioética, actualizar la configuración constitucional del matrimonio entre personas del mismo sexo; también se debe mejorar la atención a las personas con discapacidad por parte de los poderes públicos ya que se trata de un colectivo en el cual las mujeres están doblemente discriminados.

Consideramos que es imprescindible para avanzar en una sociedad más justa y solidaria el derecho a la educación en igualdad, y por ello apostamos por reconocer e implementar una educación pública, laica y gratuita como eje vertebrador del sistema educativo de calidad para el colectivo de niñas y niños. La reforma del art. 14 de la CE en pro de una igualad efectiva entre mujeres y hombres debe incluir nuevos motivos de discriminación como por ejemplo las violencias machistas, la identidad de género u orientación sexual, la trata de personas... Es en el tema de la igualdad donde hay que jugar la responsabilidad constitucional y no trivializar el debate sobre su necesaria reforma.

\section{TERESA FREIXES SANJUAN}

Es importante reformar la regulación constitucional respecto de la sucesión a la Corona, que todavía declara la preferencia del hombre sobre la mujer, pues 
hoy en día prácticamente todas las monarquías ya han establecido el criterio de primogenitura, no de varonía para la sucesión. También sería adecuado cambiar la regulación del «consorte de la Reina», pues al establecer la Constitución que existe, por una parte, la «Reina consorte» y el «consorte de la Reina» parece que se presuponga que la Reina reinante no tiene capacidad para elevar a «Rey consorte» a su cónyuge, mientras que sí lo tiene el Rey reinante, que puede convertir, por elevación a su cónyuge a la categoría de «Reina consorte».

También sería adecuado incorporar a la Constitución la fórmula empleada en la Unión Europea, que considera que la igualdad de mujeres y hombres es una característica de las presentes sociedades que conlleva el ser un valor de la Unión con todas sus consecuencias (necesaria aceptación expresa para entrar en ella y fundamento, en su caso, del procedimiento de sanción por infracción de valores). La regulación de los Tratados sobre la igualdad y no discriminación por razón de sexo u orientación sexual, así como las acciones positivas en el ámbito profesional, la igualdad en el trabajo y la transversalidad podrían tener un buen cobijo en el texto constitucional. Del mismo modo que los Tratados acogieron buena parte de las regulaciones del Derecho derivado y de la jurisprudencia comunitaria, incluir estas cláusulas en la Constitución generaría una mejor claridad reguladora y un desarrollo positivo posterior.

Utilizando una técnica semejante a la que nos permitió incluir en el Tratado de Ámsterdam las regulaciones que hoy en día se mantienen en el Tratado de Lisboa y en la Carta de los derechos fundamentales de la UE, se podrían elevar al texto constitucional regulaciones como la representación equilibrada en la toma de decisión o la lucha contra la violencia de género, así como reforzar la igualdad en el ámbito laboral, la conciliación de la vida personal y profesional o la introducción de la igualdad en la cooperación internacional y las relaciones exteriores.

\section{ITZIAR GÓMEZ FERNÁNDEZ}

A mi juicio la respuesta exige formular una aproximación un poco más amplia. La Constitución debe ser reformada porque, como he dicho antes, es preciso consolidar conquistas y solventar problemas que, con el avance de los años, se ha comprobado que no tenían adecuada respuesta constitucional.

Hay quien se refiere a la «obsolescencia de la Constitución». Si definimos obsolescencia como la cualidad atribuida a algo que ha dejado de usarse, no podemos decir que la Constitución española de 1978 haya quedado obsoleta, y menos en materia de igualdad. Las instituciones previstas en la Constitución siguen funcionando, como lo hace el sistema de garantía de los derechos fundamentales, el modelo de reparto territorial del poder — excepción hecha de lo que está sucediendo en las relaciones del Estado con Cataluña-, o el modelo de justicia Constitucional, que garantiza el respeto por la norma constitucional. 
Sin embargo, sí puede decirse, sin temor a incurrir en error, que la Constitución está desconectada de parte de la realidad jurídico-social, y el tema del reconocimiento de la igualdad de género es paradigmático a este respecto. Es decir, la CE’78 ha dejado de tener relación, comunicación o enlace con parte de la sociedad cuyas opciones políticas fundamentales, teóricamente, congrega. El problema no es la obsolescencia. Es la desconexión y la falta de apego entre la sociedad de 2018 y la Constitución de 1978. La sociedad ha cambiado en cuarenta años a una velocidad que ha llevado, a quienes nacieron en 1978, a un espacio que los distancia en dos generaciones «de pensamiento» de la de sus padres. Esa distancia entre texto y sociedad se verifica en la falta de conocimiento de la norma, y en el desapego hacia la misma y hacia su máximo intérprete. Y de esta realidad se deriva un innegable riesgo de disociación entre Constitución y pueblo soberano que, si no se gestiona adecuadamente, puede conducir a situaciones graves de conflictividad social como las que se observan en otras democracias cercanas en los últimos tiempos.

Desde luego, a mi juicio, esta observación de carácter general puede proyectarse sin muchos matices a la cuestión de la igualdad. Lo que se ha logrado en la ley no está en el texto Constitucional, y eso, no solo lo hace reversible, sino que limita su consideración como opción política de aceptación mayoritaria por el sujeto constituyente. Si la mayoría de la sociedad está de acuerdo con que la igualdad material, la lucha por la desaparición de la violencia de género, la consagración de los derechos sexuales y reproductivos, la protección de la vida familiar y los cuidados deben ser principios y derechos estructurantes de nuestra comunidad política, es preciso que ello tenga su correspondiente traducción normativa constitucional.

Cuestión distinta, y mucho más compleja quizás, sea la determinación de la forma en que tales modificaciones constitucionales deben ser formuladas. Seguramente sería razonable prever un programa de revisiones, y no una sola reforma de la totalidad del texto constitucional. Si se abordase de este modo la problemática, sería preciso plantearse, en primer término, la modificación del propio procedimiento de reforma, para asegurar la posibilidad de introducir alteraciones progresivas y organizadas en el texto constitucional. No se puede cambiar todo a la vez, pero hay temas respecto de los que ya hay consenso que sí podrían tocarse (el matrimonio igualitario, por ejemplo) y que quedan fuera de la discusión por cuanto exigen un procedimiento agravado, que algunas fuerzas políticas solo están dispuestas a abordar si es para tratar cuestiones «más importantes». En segundo término los temas respecto de los que exista acuerdo político por haber quedado consagrados ya en normas con rango de ley (organización y denominación de las CCAA, integración en la UE, paridad en las listas electorales, ajuste de las competencias del TC, etc.). Y por último aquellos que exijan de nuevos consensos constitucionales: educación, reparto competencial, sistema electoral, monarquía, etc. todo ello con la finalidad de asegurar la recuperación de la conexión entre el texto de la norma fundamental, y las opciones políticas fundamentales de la sociedad española del s. XXI. 
Una opción alternativa sería abordar, tras «la reforma de la reforma», la modificación de los derechos fundamentales, de modo tal que se trabajase primero sobre la ciudadanía y sus derechos, y sobre la obligación de promover determinadas políticas públicas tendentes a superar las fracturas sociales y desigualdad que nos han traído las crisis (económica, política y social) del primer tercio del s. XXI. A partir de ahí, logrado un modelo actualizado de reconocimiento, protección y garantía de los derechos, podría hablarse de la distribución territorial del poder, un poder que solo tiene sentido si su finalidad es asegurar el pleno disfrute de los derechos de la ciudadanía sometida a ese mismo poder. En síntesis, la reforma es necesaria. La reforma en materia de igualdad es fundamental, como lo es la reforma general en materia de derechos fundamentales para asegurar la recuperación del apego al texto constitucional. Y, en este contexto, la discusión debe superar la fase del «sí o no» a la reforma constitucional, para abordar la cuestión del «cuando», el «cómo» y el «qué».

Para responder a esta última cuestión, introduciendo la perspectiva de género, creo que habría que abordar los siguientes puntos fundamentales que, para mi conforman una suerte de decálogo de la reforma constitucional en perspectiva de género. Así, es necesario reformar la Constitución para integrar, entre las opciones políticas fundamentales: i) el respeto al principio de paridad en el reparto del poder; ii) el derecho al matrimonio igualitario y al divorcio libre; iii) el principio de igualdad de derechos y obligaciones de los cónyuges en el seno del matrimonio, y la obligación de compartir las responsabilidades domésticas y el cuidado de las personas dependientes, así como la proclamación de la igualdad plena de las personas que ostentan la tutela y/o la patria potestad en el marco de sus obligaciones y responsabilidades en relación con el cuidado y atención de sus descendientes; iv) la protección de la maternidad, como una facultad privada dotada de interés público; v) el derecho a la igualdad de trato en el trabajo entre hombres y mujeres y la igualdad de oportunidades en el mundo laboral, tanto en la vertiente del empleo público, como del empleo en el orden privado; vi) la garantía de la paridad electoral; vii) la garantía de presencia equilibrada de hombres y mujeres en los órganos del Gobierno y de la Administración - central y autonómicos-, en el Consejo General del Poder Judicial y en el Tribunal Constitucional; viii) la definición de un modelo de coeducación; ix) la consagración de los derechos sexuales y reproductivos; $\mathrm{x}$ ) el reconocimiento del derecho a una vida libre de violencia, en estrecha conexión con la preservación de la dignidad humana y la prohibición de tratos inhumanos o degradantes.

Si bien es cierto que la Constitución tiene menos capacidad taumatúrgica de la que le queremos atribuir, y que ninguno de los problemas descritos más arriba en relación con la igualdad de género se resolverán a partir de la mera previsión constitucional al respecto, resulta obvio decirlo, parece innegable también el poder simbólico de la Constitución, un poder que no es en absoluto despreciable. Como no se puede despreciar tampoco la fuerza normativa del texto constitucional, ni su capacidad para ser el espejo de la sociedad que la aprueba, así como proyección de su proyecto político. 


\section{FERNANDO REY MARTÍNEZ}

Me parece que la igualdad entre mujeres y hombres se recoge de modo suficiente y adecuado en nuestro texto constitucional, con algunos matices que luego expondré. En general, no soy partidario de «tropicalizar» el Derecho Constitucional a través de textos constitucionales que cuanto más engordan literariamente y pasan a recoger todos los sueños y deseos de todas las personas y colectivos, más frustración y escepticismo provocan simétricamente ante su seguro incumplimiento. La Constitución no es un texto mágico. No es el supermercado donde uno puede encontrar todo lo que desea. No todos los deseos pueden convertirse en derechos. Una Constitución sólo durará si es realista.

Desde luego, la reforma que no me gustaría que se hiciera es la de duplicar en femenino todos los sustantivos; es una manera agresiva de violentar nuestra lengua que, en cuanto a sus efectos, me parece inútil sino contraproducente (iy de muy mal gusto!). Por supuesto, debe revisarse todo el texto para evitar incorrecciones en cuanto al género y quizá no sobrara una cláusula genérica donde se advirtiera de que el masculino genérico empleado en el texto constitucional es eso, genérico, no sólo masculino.

La primera reforma necesaria es, por supuesto, la supresión de la preferencia masculina a la hora de suceder en la Jefatura del Estado. Participé en el Dictamen que en su día evacuó el Consejo de Estado en este sentido y comparto la propuesta que en él se hacía.

¿Sería interesante constitucionalizar algunos aspectos en relación con la lucha contra la violencia de género o las listas electorales equilibradas por género (por citar dos asuntos que han provocado cierta controversia constitucional)? Tengo dudas sobre su necesidad. Se han producido cambios legislativos de calado bajo el marco constitucional vigente que, en líneas generales, están funcionando. Tendría interés reconocerlos en la Constitución sólo para congelar su rango, evitando que se desnaturalizaran o suprimieran.

¿Debería ir la Constitución más allá y establecer directamente, por ejemplo, una composición paritaria en las principales instituciones del Estado (Cortes, Gobierno, Tribunal Constitucional, Consejo del Poder Judicial, Consejo de Estado, Tribunal de Cuentas, etc.)? Tengo dudas, pero no creo que fuera algo descartable a priori.

\section{OCTAVIO SALAZAR BENÍTEZ}

Creo que es un síntoma de algunas de las reflexiones que he apuntado en las preguntas de esta encuesta el hecho de que en la mayoría de los encuentros, congresos y publicaciones que en los últimos años se han centrado en la reforma constitucional no se le haya dedicado la más mínima atención a la perspectiva de género. Sirva como ejemplo el último congreso de la Asociación de Constitucionalistas de 
España, celebrado en Málaga en 2018, en el que solo se discutieron estas cuestiones en una mesa «alternativa» a las oficiales organizada por varias constitucionalistas. Es decir, lo más habitual es eso que de manera tan certera la constitucionalista Mar Esquembre ha denominado «el silencio sobre el ser y el estar las mujeres en la Constitución». En muchos casos resulta llamativo cómo el debate sobre la igualdad de género parece limitarse a la necesidad de superar la discriminación por razón de sexo en la sucesión a la Jefatura del Estado. No obstante, y siendo justos, no han faltado publicaciones que de manera específica se han dedicado a esta cuestión. Recordemos las monografías Género y Constitución de Blanca Rodríguez (Jurua, 2017), Una constituyente feminista, de Itziar Gómez (Marcial Pons, 2018), el monográfico de los Cuadernos de la Fundación Giménez Abad publicado en 2017 o los Estudios sobre la reforma de la Constitución en su cuarenta aniversario (Thomson Reuters, 2018), los cuales, coordinados por Yolanda Gómez, plantean unas detalladas propuestas, todas ellas desde la perspectiva de género.

Aunque los debates y las reflexiones se han centrado en cuestiones como la organización territorial, la efectiva garantía de determinados derechos o aspectos muy concretos del organigrama institucional, entiendo que la necesaria reforma de la Constitución de 1978 debería pasar no solo por incorporar la perspectiva de género en su articulado sino más bien por la apuesta por la consagración definitiva de una democracia paritaria. Paridad que, lógicamente, no hemos de entender en un sentido puramente cuantitativo, y relativo a la presencia de mujeres en los poderes del Estado, sino que ha de asumirse como un principio estructural que dé lugar a una revisión de cómo entendemos no solo el poder sino también la misma ciudadanía. Es decir, la apuesta por la conversión del Estado español en un Estado paritario, además de Social y democrático de Derecho, implica romper definitivamente, desde el mismo pacto constitucional, por un modelo de ciudadanía basado en la división público/privado y, por tanto, con unas estructuras de poder que históricamente han otorgado a las mujeres un estatuto devaluado de ciudadanía. En consecuencia, la paridad habría de proyectarse en cómo se configura el Estado de Derecho - y, por tanto, el ordenamiento jurídico, las garantías de los derechos-, en el Estado democrático —o sea, en la participación, en el ejercicio del poder, en la toma de decisiones - y en el Estado social —en cómo se garantiza el bienestar, la igualdad de oportunidades y la solidaridad. Todo ello habría de llevarnos a un Derecho Constitucional no solo más igualitario sino también más atento a las necesidades de la vida y a la protección de los bienes comunes.

Desde mi punto de vista, este compromiso debería incorporar el principio de paridad en el sentido de «mandato de optimización» (Alexy) y que, por tanto, se proyectaría tanto en la parte orgánica como en la dogmática de la Constitución. En la primera supondría revisar la composición de los poderes e instituciones teniendo en cuenta la presencia paritaria de mujeres y hombres. Todo ello partiendo, lógicamente, de la necesidad de incorporar dicho principio en la organización interna tanto de los partidos políticos como de los sindicatos y organizaciones empresariales. No hace falta insistir en la necesidad de reforma del 
art. $57 \mathrm{CE}$, como tampoco en cómo órganos como el Consejo General del Poder Judicial o el Tribunal Constitucional deberían tener una composición paritaria. Entiendo además que el reconocimiento constitucional de la paridad permitiría superar el discurso que la confunde con el mero uso de las denominadas «cuotas», las cuales pueden entenderse como un medio - por ejemplo, para promover la presencia de mujeres en las listas electorales-, pero no constituyen una herramienta que permita superar las estructuras patriarcales. Además, no habría que tener la cortedad de miras que supone entender que la paridad ha de limitarse al ámbito electoral.

En la segunda nos llevaría, entre otros aspectos, a consagrar derechos específicos de las mujeres, tales como los sexuales y reproductivos, o el derecho a vivir una vida libre de violencia. Además, habría que consagrar derechos sin los que sería imposible construir un nuevo modelo de ciudadanía (cuidadanía), tales como los de corresponsabilidad en la esfera privada, la atención de las personas dependientes, la garantía de la igualdad salarial o los vinculados a unos modelos familiares ya no necesariamente articulados a partir del matrimonio heterosexual. En este sentido sería necesario ajustar por ejemplo el derecho al matrimonio a las conquistas igualitarias e incorporar, como derechos singulares el libre desarrollo de la afectividad/sexualidad, así como las identidades de género. La incorporación de estos derechos debería plantearse además en el marco de una revisión completa de las diferentes categorías que encontramos en el Título I, de manera que se doten de mayor nivel de protección derechos sociales que en 1978 se configuraron como principios rectores. Todo ello debería ir precedido de una proclamación similar a la que por ejemplo hace el art. 3.2 de la Constitución alemana: «El hombre y la mujer gozan de los mismos derechos. El Estado promoverá la realización efectiva de la igualdad de derechos de las mujeres y los hombres e impulsará la eliminación de las desventajas existentes».

Por la incidencia que, a mi parecer, tendrían en la efectividad de la igualdad de mujeres y hombres, habría que incorporar dicho objetivo en la configuración del derecho a la educación (art. 27.2 CE), de tal manera que, por ejemplo, se despejara cualquier duda sobre la inconstitucionalidad de la educación diferenciada por razón de sexo. Es decir, habría que consagrar constitucionalmente el modelo coeducativo. En el mismo sentido, tendría que incorporarse la definición del Estado español como laico, superando así los muchos problemas que durante estos 40 años ha provocado en la práctica el deficiente art. 16.3, ya que entiendo que es un presupuesto básico para garantizar adecuadamente los derechos de las mujeres y las niñas. En esta línea, habría que dejar muy claro que el principio de igualdad, así como la dignidad e integridad física y moral de las mujeres, deberían ser un límite incuestionable frente a cualquier expresión de la diversidad cultural y/o religiosa.

Estas propuestas de reforma deberían incorporarse en un texto en el que se usara un lenguaje inclusivo, tanto al nombrar a las instituciones como al identificar a los y a las titulares de los derechos. En muchos casos será necesario además 
hacer presentes de manera expresa a las mujeres. Sería el caso, lógicamente, de los derechos sexuales y reproductivos, pero también, por ejemplo, al definir los derechos de participación política. Es importante que nuestra norma fundamental haga visibles a las mujeres en las palabras, ya que son éstas las que sirven para articular el pensamiento y para construir el imaginario colectivo. De esta manera, además, se lograría un importante efecto al proyectarse el contenido constitucional en todo el ordenamiento jurídico. Solo de esta manera, como bien han explicado expertas en esta cuestión como Mercedes Bengoechea o Eulalia Lledó, será posible romper con el masculino como referencia universal y supuestamente neutral.

Tal y como he apuntado en una respuesta anterior, estas propuestas deberían tener un presupuesto ineludible y que no es otro que la presencia paritaria de mujeres y hombres en el proceso constituyente. Es decir, el pacto constitucional al que lleguemos en plenos siglo Xxi no puede cometer el error de tener solo «padres».

En todo caso, nada de lo anterior será efectivo si, en paralelo, no llevamos a cabo una serie de reformas y transformaciones que tienen que ver con la manera en que seguimos estudiando e investigando el Derecho Constitucional, lo cual incide, lógicamente, en cómo aplicamos e interpretamos nuestro ordenamiento. No hay que olvidar que también desde y con el «discurso» se construye al sujeto. Es urgente incorporar a los presupuestos epistemológicos de la Ciencia del Derecho las aportaciones de los feminismos jurídicos, de la misma manera que a la formación de los operadores jurídicos debería incorporar una perspectiva de género que, hoy por hoy, está ausente o, en el mejor de los casos, solo es aplicada por quienes tienen la voluntad y el coraje de hacerlo. De lo contrario, continuaremos haciendo, en palabras de Sandra Harding, una «mala ciencia», lo cual tiene consecuencias sociales muy negativas ya que, como bien explica Boaventura de Sousa Santos la mayoría de las injusticias sociales tiene su punto de partida en «injusticias cognitivas».

5. ¿Cree que sin el respaldo del derecho internacional se bubiera avanzado como se ha hecho en materia de igualdad? Además de este ¿Cuáles han sido a su juicio los impulsos jurídicos o políticos que ban determinado los avances (y retrocesos) realizados?

\section{MARIA LUISA BALAGUER CALLEJÓN}

El derecho internacional y el derecho europeo han condicionado positivamente el desarrollo de la igualdad de género, aún antes de la aprobación de la Constitución. Así, en el derecho laboral, la Directiva 76/207/CEE del Consejo, de 9 de febrero de 1976, relativa a la aplicación del principio de igualdad de trato 
entre hombres y mujeres en lo que se refiere al acceso al empleo, a la formación y a la promoción profesionales, y a las condiciones de trabajo, su aplicación judicial permitió una incipiente jurisprudencia en materia no discriminatoria.

Tras la integración de España en la Comunidad Europea, hoy Unión Europea, la trasposición de las Directivas y la orientación legislativa en las normas estatales han venido determinando la exigencia de políticas de igualdad en los distintos territorios del Estado.

El Tribunal Constitucional ha recepcionado la jurisprudencia de los tribunales europeos en relación con el género, tanto en lo que se refiere al Tribunal Europeo de Derechos Humanos como al Tribunal de Justicia, y ha hecho suyas algunas de los criterios interpretativos por ellos utilizados. Así, la STC 162/2016, en lo que se refiere al «butforbest», o criterio del factor distintivo único, que resulta ser muy revelador en relación con la prueba de no discriminación, estima un recurso de amparo con remisión a la STJUE en el asunto Sarkatzis c. Imsalud por el que el Tribunal resuelve que el derecho nacional no puede ser contrario a la Directiva 2002/73/UE.

Igual sucede con los criterios interpretativos que buscan la igualdad real, detectando las discriminaciones indirectas, como los despidos en casos de embarazo, o los contratos a tiempo parcial, que repercuten negativamente en la vida laboral de las mujeres y en sus derechos pasivos.

\section{PALOMA BIGLINO CAMPOS}

No soy experta en Derecho Internacional, por lo que no me resulta sencillo dar una respuesta satisfactoria a esta cuestión. A pesar de estas limitaciones, me parece indudable, como ya he tenido ocasión de señalar, que ciertos textos internacionales han ejercido gran influencia en nuestro país. La propia Declaración de Derechos Humanos de la ONU, que aparece expresamente mencionada en el art. 10.2 CE, proclama, en su art. 1, que todos los seres humanos, y no sólo los hombres (como había sido tradicional en otros textos anteriores de iguales características), nacen libres e iguales en dignidad y derechos. Además, tanto el art. 2 como el art. 16 de dicho texto son un claro precedente de nuestra norma fundamental. También la prohibición de discriminación por razón de sexo, recogida en el Convenio Europeo de Derechos Humanos influyó, sin duda, en los redactores de nuestra Constitución. Ambos textos demuestran que, en 1978, existía un patrón universal y más en concreto, europeo, acerca de la materia, que España debía asumir para incorporarse, por ejemplo, al Consejo de Europa.

Hay muchos otros textos posteriores que pueden haber influido claramente en el desarrollo posterior de la legislación antidiscriminatoria en España, como son la Convención sobre la eliminación de todas las formas de discriminación contra la mujer de 1979 y, más recientemente, la Declaración y plataforma de acción de Beijing, de 1995, ambas elaboradas en el seno de la ONU. 
Ahora bien, me parece que el impacto que ha tenido el Derecho de la Unión Europea ha sido mayor. En este ámbito, es imprescindible recordar que, ya en 1957, los Tratados contemplaban la igualdad de retribuciones entre hombres y mujeres y que la Comunidad Económica Europea fue ya muy activa la hora de dictar Directivas imponiendo la igualdad de trato en ámbitos como la seguridad social, el acceso a bienes y servicios o la protección de la seguridad y salud de la mujer embarazada, que haya dado a luz o en periodo de lactancia.

A partir de 2006 la acción fue mucho más decidida con la Directiva 2006/54/ CE relativa a la aplicación del principio de igualdad de oportunidades e igualdad de trato entre hombres y mujeres en asuntos de empleo y ocupación. Esta norma, entre otros asuntos, define conceptos luego usados por nuestro legislador, como son la discriminación directa, la discriminación indirecta, el acoso y el acoso sexual.

Hay normas posteriores que sería farragoso reproducir, ya que aparecen detalladas en la información que brinda la Unión ${ }^{5}$, que pormenoriza igualmente la notable aportación del Tribunal de Justicia de la Unión Europea. Creo que esta influencia ha sido decisiva, no sólo como consecuencia de la primacía y el efecto directo del Derecho de la Unión, sino también por el papel que desempeña el TJUE tanto en el ordenamiento jurídico de la Unión como en los ámbitos nacionales.

\section{ÁNGELA FIGUERUELO BURRIEZA}

El discurso de los derechos humanos es un discurso de la modernidad y en el reconocimiento del derecho a la igualdad de mujeres y hombres no podemos retrotraernos más allá de los años 40 del pasado siglo xx con el nacimiento de la ONU. El trabajo de esta organización internacional en el tema que nos ocupa siempre se ha desarrollado en un doble ámbito: jurídico y político. El punto de partida del trabajo onusiano es la Carta de San Francisco de 1945. En 1946 el Consejo Económico y Social, el 16 de febrero de 1946, aprobó una resolución por la que se creó la Comisión de Derechos Humanos y la Subcomisión sobre la situación de las mujeres. Finalmente y tras muchas reuniones el día 10 de diciembre de 1948 se aprobó la Declaración Universal de Derechos Humanos que reconoce tanto en el Preámbulo como en su articulado la igualdad de derechos entre mujeres y hombres. En 1949, el Consejo Económico y Social trabajó fundamentalmente en la promoción de la igualdad en el ámbito laboral y lo hizo conjuntamente con la OIT. Ese mismo año la Asamblea General aprobó el Convenio para la supresión del tráfico de personas y de la explotación de la prostitución que afectaba fundamentalmente a las mujeres. En la década de los años sesenta la ONU

5 http://www.europarl.europa.eu/factsheets/es/sheet/59/la-igualdad-entre-hombres-y-mujeres. 
inicia una nueva etapa elaborando una serie de instrumentos jurídicos de cara a garantizar el ejercicio de los derechos y libertades de las mujeres, destacando los esfuerzos para la garantía jurídica del derecho a la igualdad. Y, en este sentido, la Asamblea en 1962, solicitó al Consejo Económico y Social la preparación de un borrador de Declaración sobre la eliminación de la discriminación sufrida por las mujeres con la intención de hacer efectivos los compromisos asumidos en la Carta de San Francisco y en la Declaración Universal de Derechos Humanos. En noviembre de 1967 la Asamblea aprobó la CEDAW (Declaración sobre la eliminación de la discriminación contra las mujeres) que es el primer texto de la ONU que afirma categóricamente que la discriminación sufrida por las mujeres, además de ser injusta, atenta contra la dignidad humana. Previamente, en 1966, los Pactos de Derechos Civiles y Políticos, y de Derechos Económicos, Sociales y Culturales hicieron en su articulado menciones específicas al ejercicio de los derechos y libertades en condiciones de igualdad para mujeres y para hombres.

La década de los años sesenta concluyó con la aprobación de una resolución de la Asamblea General para incrementar la participación de las mujeres en el ámbito de las instituciones de la ONU y con la celebración en 1968 de la I. ${ }^{a}$ Conferencia Mundial sobre Derechos Humanos. En diciembre de 1972 la Asamblea General propuso que en 1975 se celebrase el Año Internacional de las Mujeres con el objetivo de promover la igualdad, la incorporación de las mujeres al desarrollo de la sociedad y su participación en la comunidad internacional. Al mismo tiempo la Asamblea General solicitó (y fue aprobada) al Secretario General la convocatoria de la I. ${ }^{a}$ Conferencia Mundial sobre las Mujeres a celebrar en 1975 que tuvo lugar en México, concluyendo con la elaboración de un Plan de Acción en las sesiones de diciembre de 1975. Este mismo año la Asamblea General convocó la Década de las Mujeres (1975-1985); creó el Instituto de Investigaciones y Capacitación para la Promoción de las Mujeres y el Fondo de Naciones Unidas para las Mujeres (UNIFEM). Además se convocó la II. ${ }^{a}$ Conferencia Mundial para 1980 con el objetivo de evaluar los compromisos aprobados en México. Dicha Conferencia se celebró en Dinamarca.

A lo largo de esos años desde la ONU se intentó asegurar que hubiese medios suficientes para trabajar en el campo de la igualdad. Así concluyó el Programa de actividades de la Década de las Mujeres convocando y celebrando la III. ${ }^{a}$ Conferencia Mundial sobre las Mujeres que se celebró en Nairobi en 1985. Finalizó la Conferencia con unas Conclusiones plasmadas en el documento «Estrategias de acción para el adelanto de las mujeres» que fijaba las pautas de actuación a nivel mundial hasta el año 2000. Pero, en los años 90 la ONU convocó diversas Conferencias Mundiales que pretendían cubrir esos objetivos: sensibilizar a la opinión pública mundial y aprobar compromisos políticos que debían asumir los Estados.

En la línea previamente señalada se celebró la IV. ${ }^{a}$ Conferencia sobre las Mujeres, que tuvo lugar en 1995 en Pekín. A partir de esta Conferencia la ONU cambia su campo de actuación dirigiéndolo a analizar el cumplimiento y el 
seguimiento de los objetivos previamente fijados. El escaso éxito de las cuatro Conferencias Mundiales celebradas abrió un debate en la ONU que culminó con los preparativos de la Cumbre del Milenio que se celebró en el año 2000. Así se fijaron metas a corto plazo con indicadores fáciles de utilizar. Uno de los trabajos llevados a cabo en ese sentido se concretó en la aprobación de la nueva entidad «UN-WOMEN» aprobado en el año 2010. Este organismo realiza un esfuerzo importante unificando el trabajo realizado por la Comisión para el adelanto de las mujeres (CSW), el Fondo de Naciones Unidas para las mujeres (UNIFEM), el Instituto de Investigaciones para el adelanto y la formación de las mujeres (INSTRAW), el de la Red Inter para las cuestiones de género (IANWGE) y la Oficina del Asesor Especial en cuestiones de género (OSAGI).

El mandato general recibido por dicha entidad consiste en trabajar para la integración y la promoción de la igualdad de las mujeres, destacando tres áreas temáticas: la eliminación de todas las formas de discriminación contra las niñas y las mujeres, el empoderamiento femenino y la consecución de la igualdad real entre mujeres y hombres en cuanto sujetos del desarrollo, de los derechos humanos y de la acción humanitaria y la paz y seguridad. Estamos ante las coordenadas fijadas por los Estados Miembros de la ONU para resolver los problemas que afectan a las mujeres en todas las áreas geográficas y en aspectos tan variados como la democracia, la participación política, la garantía de los derechos humanos, la prevención y erradicación de la violencia de género, el cumplimiento de los objetivos del Milenio e integrar la perspectiva de género en los presupuestos y en la distribución de los recursos. Es preciso evaluar el trabajo de esta institución para ver si se cumple el objetivo fundamental: unificar el trabajo encaminado a garantizar la igualdad, en cuanto referencia transversal de todas las políticas de la ONU y de las políticas al respecto de los Estados miembros.

Es cierto que las políticas en materia de igualdad de género realizadas en el seno de la ONU tienen luces y sombras. Las debilidades y disfunciones son apreciables pero no es menos cierto que en base a los compromisos aprobados en las distintas Conferencias Mundiales las políticas públicas de los Estados miembros han atendido, en cierta medida, los compromisos internacionales. Por ello, podemos concluir que gracias a la labor de Naciones Unidas se ha llevado a cabo un proceso de sensibilización y reconocimiento de los derechos de las mujeres y en especial del derecho a la igualdad de mujeres y hombres. Al destacar la titularidad universal de derechos y libertades y sus garantías se quiere evitar que la titularidad de los mismos quede supeditada al sistema político vigente en un país o a las tradiciones consolidadas en la sociedad en que nos ha tocado vivir.

\section{TERESA FREIXES SANJUAN}

Sin el respaldo del Derecho internacional, sobre todo del Derecho de la UE, hubiera resultado mucho más difícil avanzar en materia de igualdad. De hecho, 
estos avances se han multiplicado en los países del sur de Europa desde que la UE ha ido tomando cartas en el asunto en forma decidida. Cuando, desde la sociedad civil, o desde la «expertise» se han reclamado y promovido regulaciones nuevas, ha sido mucho más fácil fundamentarlas en el Derecho de la UE, salvo en el caso de la violencia de género, ámbito en el que las legislaciones de los Estados, siendo España pionera al respecto, son mucho más precisas y garantistas.

\section{ITZIAR GÓMEZ FERNÁNDEZ}

En el ordenamiento jurídico español, la igualdad se construye, como se ha ido apuntando en las repuestas anteriores, en torno a la elaboración de normas con rango legal, y a la interpretación que la jurisprudencia ordinaria y constitucional han ido haciendo de los avances normativos. Obviamente, en este marco constructivo se coloca, como bóveda, el derecho internacional de los derechos humanos, en la rama específica destinada a reconocer los derechos de las mujeres. No sólo los grandes tratados de derechos humanos tienen una importancia fundamental en la construcción del estatuto jurídico internacional de las mujeres, en la medida en que hacen mención de la igualdad y la interdicción de discriminación por razón de sexo, sino que son muchos los instrumentos internacionales específicos que han asegurado el avance transversal y universal de los derechos de las mujeres, destacando entre todos la Convención sobre la eliminación de todas las formas de discriminación contra la mujer (CEDAW, en sus siglas en inglés).

También el Derecho de la Unión Europea ha sido fundamental para avanzar en materia de igualdad en el ámbito laboral, como demuestra el contenido de las Directivas: i) 92/85/CEE del Consejo, de 19 de octubre de 1992, relativa a la aplicación de medidas para promover la mejora de la seguridad y de la salud en el trabajo de la trabajadora embarazada que haya dado a luz o esté en periodo de lactancia (modificada por la Directiva 2007/30/CE de 28 de junio de 2007); ii) 2006/54/CE del Parlamento Europeo y del Consejo de 5 de julio de 2006, relativa a la aplicación del principio de igualdad de oportunidades e igualdad de trato entre hombres y mujeres en asuntos de empleo y ocupación; iii) 2010/41/ UE del Parlamento Europeo y del Consejo de 7 de julio de 2010, sobre la aplicación del principio de igualdad de trato entre hombres y mujeres que ejercen una actividad autónoma; iv) 2010/18/UE del Consejo de 8 de marzo de 2010, por la que se aplica el Acuerdo marco revisado sobre el permiso parental, celebrado por BUSINESS EUROPE, la UEAPME, el CEEP y la CES. Todas estas Directivas, transpuestas al ordenamiento español, han definido las modificaciones del mercado laboral español, y de las relaciones funcionariales para asumir plenamente el principio de igualdad de acceso, promoción y desarrollo profesional entre hombres y mujeres.

Obviamente, las Conferencias Internacionales de Copenhague (1980), Nairobi (1985) y Beijín (1995), donde se adopta la Declaración de Beijing y se crea 
la Plataforma de acción resultante de dicha Declaración, con la reformulación de esta última desarrollada en la Conferencia sobre Desarrollo Sostenible de Río de Janeiro de 2015, han marcado las pautas estructurantes de la política internacional en materia de igualdad de género, y han tenido su reflejo en la evolución de las políticas nacionales. La conexión entre el nivel nacional y el nivel internacional, en esta materia, es innegable. No sé qué hubiera sucedido sin el respaldo del Derecho Internacional en esta materia, pero sí sé que el mismo ha legitimado muchas decisiones políticas de indudable utilidad para garantizar el avance de las políticas públicas en este ámbito. Y me parece interesante ofrecer un ejemplo de la interconexión entre estos dos niveles de garantía de los derechos humanos de las mujeres: la Sentencia de la Sección cuarta de la Sala de lo Contencioso Administrativo del Tribunal Supremo (Sentencia n. ${ }^{\circ}$ 1263/2018): en este pronunciamiento el Tribunal Supremo reconoce la responsabilidad patrimonial del Estado español por no haber dado cumplimiento a lo establecido en el Dictamen 47/2012, de 16 de julio, del Comité de la Convención sobre eliminación de todas las formas de discriminación contra la mujer (CEDAW), que condenaba a España por incumplimiento de las obligaciones de La Convención en el caso del asesinato, a manos de su padre, de la hija de Ángela González Carreño, víctima de violencia de género. En el fundamento jurídico cuarto de la sentencia el Tribunal Supremo afirma: "El Derecho Internacional y las obligaciones internacionales contraidas por España son Derecho que el Estado, como Estado democrático de Derecho, debe respetar y aplicar efectivamente de manera que los derechos y libertades que la Constitución y los tratados internacionales celebrados por España proclaman, sean reales y concretos. Por ello, ante la inexistencia de un procedimiento específico de ejecución de los dictámenes del Comité de la CEDAW, que es en sí mismo un incumplimiento de un mandato legal y constitucional por parte España, el que la recurrente pueda disponer de un cauce adecuado y eficaz para hacer valer el reconocimiento de la vulneración de sus derechos fundamentales ante los órganos judiciales españoles atañe directamente al respeto y observancia por los poderes públicos españoles de los derechos fundamentales de la recurrente».

\section{FERNANDO REY MARTÍNEZ}

El derecho internacional ha jugado un papel clave en la generalización del derecho antidiscriminatorio en nuestro país. En general, el derecho internacional de los derechos humanos se ha convertido en un factor de creación legislativa o, sobre todo, judicial de nuevos derechos o de nuevas dimensiones de derechos ya existentes. Respecto del derecho antidiscriminatorio esto es más que evidente. Así como en el campo de las instituciones las soluciones varían notablemente de un país a otro, en el ámbito de los derechos fundamentales los problemas son comunes y, a menudo, las soluciones también. Las dos fuentes principales de creación de derechos son la nueva interpretación de qué significa la autonomía personal (normalmente a través de la cláusula del derecho a la vida privada, la 
privacy anglosajona, o del libre desarrollo de la personalidad o de la misma idea de dignidad) y el creciente contenido que se atribuye a la noción de igualdad y, sobre todo, de prohibición de discriminación. El derecho antidiscriminatorio surge en los Estados Unidos, se desarrolla en el orbe anglosajón, de ahí pasa al derecho de la Unión Europea y, finalmente, a los Estados, entre ellos el nuestro. Curiosamente, el criterio sospechoso que dio origen al derecho antidiscriminatorio en Estados Unidos fue el racial y, a partir de él, se fue desarrollando el resto, mientras que en Europa el elemento central ha sido desde el principio el sexo/ género y sólo más tarde se ha ido expandiendo al resto de criterios (raza/etnia, discapacidad, edad, orientación/identidad sexual, ideología/creencias).

La igualdad entre mujeres y hombres forma parte de la política social de la Unión Europea e integra el acervo comunitario. La entrada en vigor del Tratado de Ámsterdam (de 2 de octubre de 1997), el 1 de mayo de 1999, marcó un hito en la política de igualdad de la UE. Hasta entonces, los textos constitutivos tan sólo mencionaban el principio de igualdad de retribución en una disposición aislada, el antiguo artículo 119 del Tratado Fundacional de 1957. Tan limitado fundamento legal no impidió que la Comisión Europea impulsara desde principios de los años 70 directivas, programas e iniciativas de financiación, a la vez que abanderaba campañas de sensibilización. La «percha» del artículo 119 TCE resultó así ser el útil fundamento jurídico sobre el que se fue abriendo camino, vía derecho derivado, la política europea de la igualdad de género. La disposición más importante e influyente del derecho comunitario en esta materia fue la Directiva 76/207/CEE sobre la aplicación del principio de igualdad de trato entre hombres y mujeres en lo que se refiere al acceso al empleo, a la formación y a la promoción profesionales, así como a las condiciones de trabajo. Esta Directiva ha sido modificada el 23 de septiembre de 2002 para adaptarla a la evolución de la jurisprudencia y al Tratado de Ámsterdam, así como para incluir nuevas disposiciones relativas a cuestiones importantes, como el acoso sexual y su consideración como una discriminación directa, y finalmente, ha sido «codificada» junto con el resto de Directivas sobre igualdad entre mujeres y hombres por la Directiva 2006/54. La Ley orgánica 3/2007, de 22 de marzo, para la igualdad efectiva de mujeres y hombres es la norma que, fundamentalmente, transpone en nuestro ordenamiento los principios y reglas provenientes del derecho europeo.

Así pues, el Derecho de la Unión Europea ha jugado y juega todavía un papel fundamental en la vigorosa comprensión de la igualdad de género en nuestro país. Sin embargo, y esta diferencia contrasta de modo importante con lo que ocurre con la mayoría de derechos fundamentales, el Consejo de Europa, con su Tribunal de Estrasburgo a la cabeza, apenas ha desempeñado una función relevante en este campo.

Y, por el contrario, y también a diferencia de lo que suele ser común con el resto de derechos, el derecho de Naciones Unidas sí es relevante en el desarrollo del derecho a la igualdad de género. Un hito en la evolución del este derecho en nuestro país y en todo el mundo es la IV Conferencia de Naciones Unidas sobre 
la Mujer celebrada en Beijing entre el 4 y el 15 de septiembre de 1995. En esta Conferencia se sustituye la noción de «igualdad de la mujer» por la contemporánea «igualdad de género»; se introducen conceptos clave como el de empoderamiento o transversalidad; se reconoce claramente la igualdad de género como un derecho humano; se introducen nuevas garantías institucionales y se indican las áreas u objetivos estratégicos de lucha por la igualdad (educación, economía, pobreza, poder, medios de comunicación, salud, violencia, conflictos armadas, las niñas, medio ambiente). Esta nueva metodología fue implantada en España a través de los planes estatales, autonómicos e incluso locales de igualdad de género; y dio lugar a la creación de nuevas figuras profesionales como las de agente de igualdad de oportunidades.

Además, Naciones Unidas cuenta con un importante tratado, la Convención sobre la eliminación de toda forma de discriminación contra las mujeres (1979), publicado en España el 21 de abril de 1984. Nuestro país ha suscrito el Protocolo Facultativo que permite a particulares y asociaciones elevar denuncias directamente al Comité CEDAW. Este Comité evacúa interesantes informes periódicos sobre la situación de la igualdad de género en España (el último es de 2015) y formula valiosas recomendaciones y propuestas de mejora.

En definitiva, el derecho internacional de los derechos humanos juega en este campo un papel crucial porque, entre otras cosas, impide o dificulta cualquier retroceso. Junto con él, no cabe ignorar la enorme influencia que también ejerce el derecho comparado. Obviamente, el derecho comparado, a diferencia del internacional, no es norma jurídica vinculante en nuestro país, pero no por ello hay que desdeñar su impronta. Ya tuvimos oportunidad de comprobarlo, por ejemplo, en relación con la extensión del derecho de sufragio a las mujeres. El hecho de que otros países, que servían como nuestro modelo, lo hubieran hecho ya, fue, sin duda, un acicate eficaz. Lo mismo podría decirse de la composición equilibrada por género de las listas electorales, reconocidas antes en Francia o Italia.

Desde mi punto de vista, los principales impulsores de las políticas de género en España han sido los gobiernos socialistas. Antes indiqué la importancia capital de la creación del Instituto de Género y, sobre todo, de las cuotas electorales de género, tanto internas como de cargos de representación, a imitación del partido socialista alemán. Más tarde, y por no mencionar el serio intento de suprimir la preferencia del varón en el orden sucesorio del trono, otros dos cambios políticos de calado han sido la exigencia de composición equilibrada de las listas y toda la nueva estrategia de lucha contra la violencia de género creando, incluso, una jurisdicción especializada.

El valor que (creo) debe reconocerse a las políticas socialistas en favor de la igualdad de género se debe extender sistemáticamente a los avances que también ha procurado respecto de la igualdad por orientación e identidad sexuales. La discriminación que sufren los homosexuales se produce, a mi juicio, por causas claramente machistas, de modo que luchar contra la discriminación por estas razones es también luchar por la igualdad de género. El reproche ideológico a las personas 
homosexuales trae causa de que un hombre o una mujer se atreven a adoptar en el ámbito sexual el papel «pasivo» que tradicionalmente se atribuía al sexo contrario. Es un hombre que actúa como una mujer y una mujer que quiere ser un varón sin serlo. De ahí que las sociedades más machistas sean también las más homófobas: las ideas enfermas que dan origen a la discriminación provienen de la misma factoría.

\section{OCTAVIO SALAZAR BENÍTEZ}

Creo que los avances que se han ido consiguiendo en materia de igualdad son el resultado de la suma e intersección de muchos factores y actores, pero sin duda hay dos sin los cuales sería imposible explicar las progresivas conquistas que se han ido alcanzado en estos 40 años de democracia. Sin duda, el Derecho Internacional ha jugado un papel esencial desde varios puntos de vista: a) ha contribuido a consolidar el presupuesto básico de que los derechos de las mujeres son también derechos humanos; b) ha aportado una dimensión global sobre la discriminación sistémica que sufren las mujeres; c) ha ido generando una serie de conceptos, herramientas y nuevos paradigmas que han sido decisivos en la revisión de una cultura jurídica construida a imagen y semejanza de los varones. Los mismos conceptos que hoy día han acabado por asentarse, a pesar de las polémicas que en muchos casos han generado, tales como acción positiva, mainstreaming de género, discriminación interseccional o democracia paritaria, provienen de una acción internacional que ha tenido como principal punto de referencia las Conferencias Internacionales sobre derechos de las mujeres celebradas desde la década de los 70 del pasado siglo. A todo ello habría que sumar la apuesta de la Unión Europea por incorpora la igualdad de mujeres y hombres como uno de los principios esenciales de este «experimento» político-jurídico. Con sus luces y sus sombras, la jurisprudencia tanto del TEDH como del Tribunal de Justicia de la Unión Europea han sido una herramienta clave, por ejemplo, en cómo el TC ha ido construyendo la ciudadanía de las mujeres a partir de las dos dimensiones, formal y material, de la igualdad.

Todo lo anterior debería constituir un punto de partida irrenunciable de cara a una futura reforma constitucional con perspectiva de género. Es decir, entiendo que España estaría obligada no solo a no contradecir las normas internacionales ratificadas sino también a incorporar, a nivel constitucional, una serie de previsiones que en 1978 no se tuvieron en cuenta. En este sentido, sí que creo que el Derecho Internacional de los derechos humanos, y en este caso de los derechos humanos de las mujeres, impondría determinados límites al poder constituyente. Pensemos por ejemplo en todo lo que el conocido como Convenio de Estambul de 2011 plantea en torno a las violencias sobre las mujeres.

Pero junto a ese impulso del Derecho Internacional, no deberíamos olvidar que todas las conquistas y todos los procesos de transformación, muchos de ellos 
todavía por concluir e incluso en algún caso por iniciar, se han producido gracias a la permanente movilización feminista y al trabajo incansable y continuo de los colectivos de mujeres que han sido decisivos en la articulación de la sociedad civil. De hecho, la que ya estamos viviendo como «cuarta ola» del feminismo sería impensable sin la acción política de mujeres, tanto a nivel individual como colectivo, que han conseguido situar en la «agenda pública» cuestiones que hasta hace nada eran invisibles o, a lo sumo, secundarias. En esta línea, son muchas las mujeres que, desde los partidos políticos, y a pesar de todos los obstáculos que siguen encontrando en estructuras orgánicas resistentes a superar los privilegios masculinos, han realizado una labor impagable para que las leyes, las políticas públicas y la sociedad en general incorporarse como un objetivo prioritario la lucha contra la desigualdad. De otra manera habría sido imposible, por ejemplo, que en nuestro país se generase en apenas una década una conciencia sobre el problema social y político que representa la violencia de género. Justamente por ello creo que es de justicia, llegado el 40 aniversario de la Constitución, reconocer a todas esas mujeres que, en condiciones ciertamente adversas, han ido erosionando un modelo político y jurídico, en muchos casos en detrimento de sus mismas aspiraciones profesionales y/o políticas.

Además, ninguna de las transformaciones producidas en materia de igualdad de derechos, y mucho menos en cuanto a la revisión que se ha ido provocando de las mismas bases teóricas y epistemológicas del Derecho y la Ciencia Jurídica, habría sido posible sin el trabajo de reflexión crítica llevado a cabo por las compañeras juristas que han ido, en muchos casos también en condiciones adversas, generando toda una corriente de pensamiento jurídico crítico sin el cual, por ejemplo, ciertos instrumentos legislativos no habrían visto la luz. O, como mínimo, no se habrían articulado de la misma manera. En este sentido, creo que ha sido y es esencial la tarea desempeñada desde hace años por la Red Feminista de Derecho Constitucional, así como de manera más reciente, y más vinculada a la praxis judicial, la que lleva a cabo la Asociación de Mujeres Juezas de España. Todo ello, insisto, en contextos, como el universitario, en el que todavía hoy los estudios de género carecen del reconocimiento debido y en el que el control de los saberes y las prioridades ha estado y está mayoritariamente en manos de hombres. Y no precisamente hombres a los que pudiéramos considerar como «aliados» del feminismo.

En cuanto a los retrocesos que en políticas de igualdad se han producido en la última década, coincidiendo en gran medida con los años de la crisis económica y con la consagración constitucional del principio de estabilidad presupuestaria, son varios los factores que han coadyuvado a la fragilidad de las conquistas. De manera esquemática, podríamos señalar algunas causas: a) La debilidad de los instrumentos legislativos, carecen en muchos casos de dimensión coactiva y de un desarrollo reglamentario que los dote de eficacia; b) La carencia de la suficiente dotación de recursos, materiales y humanos, para aplicar de manera efectiva las acciones previstas; c) La pervivencia, solo mínimamente erosionada, de un sistema de división 
sexual del trabajo y de unas políticas — laborales, económicas, fiscales - basadas en la oposición hombre proveedor/mujer cuidadora; d) La ausencia de una cultura jurídica que haya integrado la perspectiva sistémica de la discriminación por razón de género; e) En estrecha conexión con el anterior, la escasa formación y sensibilización de los operadores jurídicos en esta materia; f) El desequilibrio desde el punto de vista del género en la composición de instituciones clave, tales como el Tribunal Constitucional o el Consejo General del Poder Judicial; g) Las frágiles políticas en materia educativa, en todos los niveles, con la consiguiente repercusión negativa en la formación de los y las profesionales de los diferentes ámbitos, así como en la sociedad en general.

Todo ello, recordemos, en el marco de una Constitución en la que, como he señalado, las mujeres están ausentes, el género es invisible y la paridad ni se adivina. A lo que habría que añadir, por ejemplo, carencias tal flagrantes como el no reconocimiento como fundamentales de derechos sociales sin los que es imposible garantizar la autonomía que define a los sujetos democráticos. La suma de estos elementos ha provocado que con demasiada frecuencia las políticas de igualdad queden en manos del voluntarismo político y que sean con facilidad sacrificadas ante otros intereses considerados más prioritarios. En este sentido, no debemos olvidar cómo en buena medida las políticas de igualdad requieren unas sólidas, permanentes y no regresivas dotaciones presupuestarias, ya que se traducen, entre otras cosas, en prestación de servicios y en dotación de recursos que permiten remover la desigualdad. Por tanto, ha sido demasiado frecuente su sacrificio en momentos de estrechez presupuestaria. De ahí que cualquier evaluación rigurosa que pretenda hacerse sobre la efectividad de las políticas de igualdad debe pasar por el análisis crítico de la Ley de Presupuestos, por el régimen fiscal o por cómo el género se introduce como categoría transversal en las políticas económicas. Una evaluación crítica que en la práctica no se realiza, o se realiza de manera insatisfactoria, entre otras cosas porque, como antes he apuntado, el mandato de que los proyectos de ley y los planes del Gobierno vayan acompañados del preceptivo informe de impacto de enero acaba convertido en la práctica en una mera formalidad que apenas incide en los contenidos normativos.

6. ¿Qué valoración le merece la interpretación que ha realizado el Tribunal Constitucional del principio de igualdad entre mujeres y hombres? ¿Considera que el juicio de igualdad, en este caso, tiene singularidades que lo diferencian de los otros «rasgos sospechosos» del art. 14?

\section{MARIA LUISA BALAGUER CALLEJÓN}

La jurisprudencia del Tribunal Constitucional, en relación con los derechos de las mujeres, ha sido muy positiva, y ha permitido un desarrollo de la igualdad 
muy importante, validando todas las leyes sometidas a control de constitucionalidad, e interpretando la igualdad reconocida en la Constitución, con criterios muy ajustados a la doctrina antidiscriminatoria, y a las acciones positivas de igualdad. En general, la jurisprudencia de valores que el Tribunal ha realizado en torno a la igualdad, y en concreto a la igualdad de género, permite afirmar que ha contribuido a cambiar de manera muy importante la jurisprudencia conceptual en que se venía desenvolviendo la jurisdicción ordinaria, fundamentalmente en los primeros años de la justicia constitucional.

En las primeras sentencias, referentes todas ellas a las excedencias forzosas por matrimonio, el Tribunal consideró contraria a la Constitución la norma que obligaba a las mujeres a abandonar su puesto de trabajo al contraer matrimonio y obligó a la readmisión o indemnización de esas mujeres en organismos públicos. Lamentablemente aquí el Tribunal consideró la prescripción de las acciones en un plazo de tiempo muy limitado, de tres años, en función de la ley de procedimiento laboral entonces vigente, lo que no produjo los efectos de generalización en la reparación del daño, pero en su línea de razonamiento se expresaba con claridad una posición de búsqueda de la igualdad material entre mujeres y hombres, muy pronto puesta de manifiesto en los criterios de desigualdad compensatoria que se materializaron en numerosas sentencias.

Es cierto que la vía de penetración del concepto clave para la aplicación de esa igualdad material entra en la jurisprudencia por la vía del voto particular en la STC 103 /1983, dictada en una cuestión de inconstitucionalidad en relación con la jubilación solicitada por un hombre, y denegada por limitarse la legislación del momento a las mujeres. El voto discrepante hace referencia a la justificación de la diferencia por tratarse de situaciones que no eran homologables, al ser la mujer la que mayoritariamente en la sociedad española de la época, llevaba a cabo las funciones del hogar y no tenía una actividad remunerada. La STC 128/1987 adopta el criterio establecido en ese voto como posición mayoritaria y consolida el derecho una desigualdad compensatoria de las mujeres respecto de los hombres, en un plus de guardería, justificada por la mayoritaria atención de las mujeres a sus hijos.

Es en este campo, de la maternidad, en el que más atención se ha prestado por parte del Tribunal a una jurisprudencia atenta a las discriminaciones indirectas, otra técnica interpretativa facilitadora de la igualdad real. Los despidos aparentemente objetivos, llevados a cabo en mujeres embarazadas, han sido presumidos como lesiones al derecho de igualdad en el trabajo.

Quizás se pueda hablar de un punto de inflexión en esta jurisprudencia con la STC 126/1987, en la que se desestima una cuestión de inconstitucionalidad y se declara conforme a la Constitución la aplicación del derecho histórico del que se derivaba la regla de preferencia del varón sobre la mujer, en el orden regular las transmisiones mortis causa de los títulos nobiliarios. Es importante sin embargo considerar el VP del Magistrado Cruz Villalón, que pone de relieve la escasa calidad técnica de la sentencia, y en todo caso, se trató de un hecho aislado, 
que por otra parte, como es sabido, se corrigió por el legislador en la Ley 32/2006, de 30 de octubre, sobre la igualdad del hombre y la mujer en la sucesión de los títulos nobiliarios.

En relación con los rasgos sospechosos, y antes de la vigencia de la LO 3/2007, el TC había venido desarrollando técnicas interpretativas que no siendo exclusivas de la igualdad de género, resultaban muy positivas para la discriminación de las mujeres: la razonabilidad, la proporcionalidad, el término de comparación, y las acciones positivas o discriminación positiva, han permitido avances muy importantes.

Así, las numerosas sentencias dictadas en relación con las cuestiones de inconstitucionalidad planteadas contra el art. 153.1 CP, desde la STC 59/2008, en la redacción dada por la LO 1/2004, de 28 de diciembre para de medidas de protección integral contra la violencia de género, o la que desestima el recurso de inconstitucionalidad contra la LO 3/2007, de 22 de marzo, para la igualdad efectiva de mujeres y hombres, STC 12/2008, y similares sobre leyes de las CC.AA. que habían regulado la participación electoral. (SSTC 13/2009, 40/2011).

\section{PALOMA BIGLINO CAMPOS}

Llevar a cabo un análisis de la jurisprudencia del Tribunal Constitucional en materia de igualdad entre hombres y mujeres excede claramente de los objetivos de una encuesta y entra de lleno en el ámbito de la investigación. Por estas razones, me parece necesario destacar que, en general, su aportación ha sido decisiva, no sólo a la hora de depurar el ordenamiento de medidas paternalistas, sino también a la hora de asegurar la igualdad entre hombres y mujeres en múltiples situaciones. Las dos decisiones que, sin duda, revisten mayor interés, fueron la STC 12/2008, sobre las listas electorales de composición equilibrada y las STC 59/2008, sobre la reforma del Código Penal en materia de delitos de violencia de género.

La primera de ellas, que confirmaba la constitucionalidad de la norma, puso a nuestro Tribunal Constitucional muy por delante de sus homólogos italiano y francés. Estos órganos habían invalidado leyes menos avanzadas invocando, paradójicamente, el principio de igualdad entre hombres y mujeres. La segunda tuvo muy en cuenta la naturaleza especialmente odiosa de esos delitos y la frecuencia con que la mujer es víctima de ellos. En ambas decisiones el Tribunal estuvo a la altura de las circunstancias: lejos de escudarse en análisis meramente formales, fue capaz de conectar la norma con la realidad en que se aplica.

Evidentemente, la discriminación por razón de género tiene rasgos mucho más sospechosos que las otras causas de discriminación mencionadas en el art. 14. La principal de todas ellas es su carácter horizontal, en virtud del cual se superpone, y agrava, al resto de posibles discriminaciones, lo que las transforma en múltiples. 


\section{ÁNGELA FIGUERUELO BURRIEZA}

Como previamente ya he señalado el art. 14 de la CE reconoce el principio de igualdad ante la ley en el más puro sentido de la doctrina del Estado liberal; así, proclama la igualdad de los españoles ante la ley y prohíbe cualquier discriminación en una serie de categorías sospechosas de discriminación (pero no las agota porque termina su redacción con una cláusula general en la que cabe como causa discriminada cualquier condición o circunstancia personal o social). Se citan como categorías discriminadoras el nacimiento, la raza, la religión, la opinión y el sexo. En la redacción de este precepto constitucional el principio de la igualdad de mujeres y hombres se difumina porque el legislador constituyente considera que los sujetos afectados por la discriminación son seres neutros y con ello no se pone el acento en que «el sexo» es un factor de desigualdad histórico y las desigualdades de mujeres y hombres no son puntuales ni coyunturales; la exclusión persiste, es estructural y expulsa a las mujeres (más de la mitad de la población) del sector público como también las excluyó del pacto constitucional.

Tradicionalmente el espacio reservado a las mujeres era el privado y doméstico; espacio que no participaba del sector público reservado únicamente a los varones. Los niveles entre lo privado y lo público no eran equiparables y en esa perspectiva los principios constitucionales no ocupan todos los espacios al mismo nivel. De ahí que «el sexo» como causa de discriminación reconocida en el art. 14 constitucional no pueda ser considerado al mismo nivel que el resto de categorías sospechosas de discriminación; además, que la simple introducción en dicho precepto en la norma suprema no es suficiente para erradicar las desigualdades entre mujeres y hombres; es pues imprescindible un nuevo pacto constitucional — por medio del procedimiento de revisión atribuido al poder constituyente constituido- que identifique y permita visibilizar a ambos sexos como sujetos plenos de derechos.

Conviene también destacar que tanto a nivel doctrinal como jurisprudencial (protección multinivel de derechos) la naturaleza jurídica de las distintas causas de discriminación, recogidas en la normativa internacional, comunitaria y nacional, se ha ido elaborando a partir de la prohibición de la discriminación por razón de sexo. A ello ha contribuido también la Ley Orgánica 3/2007 de 22 de marzo, para la Igualdad efectiva de mujeres y hombres. Y, a dichos efectos cuando hablamos de discriminaciones por razón de sexo hay que diferenciar distintas categorías reconocidas en la LOI, y previamente en la Jurisprudencia del Tribunal de Luxemburgo y en las Sentencias de nuestro Tribunal Constitucional: discriminaciones directas, discriminaciones indirectas, discriminaciones ocultas, discriminaciones por indiferenciación, discriminación por asociación, discriminación por error y discriminación múltiple...

Las discriminaciones directas (art. 6.1 de la LOI) son aquellas situaciones en que se encuentra una persona tratada de manera menos favorable que otra en 
situaciones comparables. En esta categoría encuadramos, por ejemplo, las discriminaciones por embarazo o maternidad y las diferentes remuneraciones salariales a mujeres y hombres por un trabajo de igual valor. Por su parte las discriminaciones indirectas (art, 6.2 de la LOI) son aquellas situaciones en que una disposición, criterio o práctica, que en apariencia son neutros, ponen a personas que se encuentran en la misma situación en desventaja sin que pueda haber una justificación objetiva y razonable. Por ejemplo, primar la movilidad laboral en el empleo perjudicando de forma indirecta a las mujeres que son quienes arrastran en mayor medida las cargas familiares. Otra categoría son las discriminaciones ocultas que sin tomar como referencia una categoría sospechosa de discriminación encubren diferencias injustificables por cualquier motivo. También encontramos otras discriminaciones por indiferenciación, por asociación, por error o las discriminaciones múltiples. Estas últimas categorías discriminatorias aparecen reconocidas en el articulado de la Ley Integral contra la violencia de género de 2004.

En el art. 7 de la LOI se alude al acoso discriminatorio que se produce cuando se dan conductas basadas en las precitadas causas de discriminación para atentar contra la dignidad de una persona creando un entorno cuando menos hostil e intimidatorio. Tampoco podemos dejar de aludir a las medidas de discriminación inversa reconocidas en la normativa internacional y nacional objeto de desarrollo en la tutela multinivel de derechos: dichas medidas van encaminadas a hacer desaparecer las desigualdades que persisten entre mujeres y hombres. No atentan contra el principio de igualdad porque son medidas promocionales (principio de igualdad material) para corregir la situación discriminatoria que sufre el sexo menos representado (a título de ejemplo la STC 12/2008, de 29 de enero) sobre el principio de presencia equilibrada en las listas electorales que reconoce la LORET por imperativo de la LOI (Disposición adicional primera). El Tribunal Constitucional español defiende la constitucionalidad de la medida a partir del art. 9.2 de la CE que pretende alcanzar la igualdad real y efectiva. Las medidas de acción positiva se regulan en el art. 11 de la LOI y deben tener una duración temporal (es decir mientras dure la situación de discriminación que las justifica).

\section{TERESA FREIXES SANJUAN}

Ha sido una igualdad «evolutiva». Primero muy tímida y precisamente haciendo que determinados colectivos masculinos se equiparasen a «ventajas» que tenían las mujeres en sus ámbitos (pensiones, por ejemplo). Después ya se ha entrado en una aceptación de los indicadores proporcionados por el Tribunal Europeo de Derechos Humanos y por la legislación y jurisprudencia de la UE. Hoy en día, salvo alguna contada excepción, podemos considerar que la jurisprudencia del Tribunal Constitucional es avanzada, pionera en algunos casos si comparamos con otros países. 


\section{ITZIAR GÓMEZ FERNÁNDEZ}

Creo que, durante 35 años el Tribunal Constitucional ha ido supliendo, por vía interpretativa, y desde una clara opción a favor de una interpretación evolutiva de la Constitución, los silencios de esta última en materia de igualdad de género, y que la valoración de esa jurisprudencia debe ser positiva.

Ahora bien, es preciso reconocer que tal jurisprudencia ha sido elaborada por un Tribunal de hombres. Desde el año 1980, el Tribunal Constitucional se ha visto conformado por 57 magistrados y 6 magistradas. No más de dos mujeres han ocupado simultáneamente la Alta Magistratura Constitucional. No hubo ninguna magistrada durante casi una década, concretamente entre el año 1989 en que Gloria Begué dejó la Magistratura y el año 1998 en que se incorporó Maria Emilia Casas. Después de ella, entrarían a integrar el Tribunal Elisa Pérez Vera (20012012), Adela Asua (2010-2017), Encarnación Roca (2012) y Maria Luisa Balaguer (2017), las dos últimas aún en el ejercicio del cargo. Una de ellas ejerció la Presidencia. Cuatro la Vicepresidencia.

Y junto a este primer lamento, se ha de elevar otro: la jurisprudencia constitucional no distingue las desigualdades basadas en el sexo de cualesquiera otras discriminaciones fundadas en causas sociales, ideológicas, personales y de cualquier otro tipo. Además el Tribunal no realiza una construcción específica sobre el género, sino que habla indistintamente de sexo y género (STC 159/2016), a pesar de que parece apreciarse cierta conciencia de la distinción en la STC 59/2008. Esa indiferenciación entre las categorías sospechosas de inducir comportamientos discriminatorios, supone que el Tribunal juzga la distinción por razón de género con el mismo método racional con que juzga las demás, buscando la causa de la discriminación y las razones que justifican su existencia, para valorar después si tal justificación es constitucionalmente admisible o no lo es. Y ese método no siempre conduce a los mismos resultados, porque es esencialmente relativista y analiza el caso perdiendo de vista el contexto de discriminación estructural en que se desarrolla la vida de las mujeres. Y porque ignora el hecho de que las medidas previstas en el ordenamiento y sometidas a enjuiciamiento constitucional no producen efectos aislados o unidireccionales, sino que actúan en un contexto determinado y contemplan proyecciones múltiples.

A mi juicio este error en el enfoque ha conducido, particularmente en los últimos años, a la elaboración de varias sentencias que parecen involucionar en materia de interpretación de principio de igualdad y que, por ello, entiendo que obligan a introducir matices en un balance inicial esencialmente positivo

La STC 145/2015, de 25 de junio, estima el recurso de amparo planteado por un farmacéutico al que se sancionó por no dispensar en su farmacia la píldora del día después. El voto particular de la magistrada Adela Asúa pone de manifiesto que la sentencia «minimiza la debida consideración acerca de los derechos a la vida y a la integridad física y moral y a la salud de las personas que puedan requerir la utilización del medicamento en cuestión» 
Las SSTC 31/2018 y 76/2018 dan carta de naturaleza constitucional a la educación diferenciada por sexos, olvidando, tal y como ponen de manifiesto los votos particulares, entre ellos el de la Magistrada María Luisa Balaguer, que la educación diferenciada no se compadece adecuadamente con el principio de igualdad entre hombres y mujeres constitucionalmente reconocido. No cabe, en una visión actual del principio de igualdad entre géneros, un postulado que defienda el «separados pero iguales».

Las SSTC 111/2018 y 117/2018 desestiman los recursos de amparo planteados por la Plataforma por permisos iguales e intransferibles de nacimiento y adopción (PPiiNA) reclamando la igualación de los permisos de maternidad y paternidad, ya que obvian que, como se recoge, de nuevo en un voto de Balaguer, la diferencia entre unos y otros es una barrera de entrada de las mujeres al mundo laboral y supone una discriminación indirecta indiscutible

Y, por último, el ATC 119/2018, inadmite a trámite el recurso de amparo planteado por una Magistrada que cuestionaba la falta de respeto del principio de igualdad en los nombramientos discrecionales efectuados por el CGPJ. De nuevo aquí los votos particulares pronunciados ponen de relieve la falta de adecuada ponderación del elemento de discriminación sistémica de las mujeres en el acceso a la cúpula del poder judicial.

En suma, varios ejemplos que ponen de manifiesto la necesidad de revisar la última jurisprudencia constitucional con perspectiva crítica, y de trabajar por el desarrollo de cánones argumentativos diversos, demostrada la insuficiencia, en el tiempo presente, de los desarrollados durante tres décadas.

\section{FERNANDO REY MARTÍNEZ}

Obviamente, la discriminación por género es diferente a todas las demás por las razones que antes expuse (la más antigua, extendida, proteica y básica), pero también porque no afecta a una minoría, a un «colectivo» sino a la mayoría demográfica de la población y porque se añade a todas las demás, configurando ataques específicos y más graves a la dignidad de las personas. Esto nos lleva a plantearnos si la igualdad de género debiera seguir sistemáticamente ubicada en la cláusula antidiscriminatoria, como hasta ahora, o debiera emanciparse para convertirse en un derecho fundamental con perfiles totalmente específicos. La cuestión va más allá de la simple colocación en un mismo artículo, junto con el resto de «rasgos sospechosos», como hasta ahora, o en dos separados, dedicando uno expresamente a la igualdad de género. Se trata de valorar si, en definitiva, la igualdad de género es un quid diferente al de los otros ámbitos del derecho antidiscriminatorio.

En cuanto a la interpretación que ha venido realizando el Tribunal Constitucional de la prohibición de discriminación por sexo del art. $14 \mathrm{CE}$, es posible concluir que ha sido abundante, garantista y casi siempre ha resuelto correctamente 
los casos planteados (aunque no en todos ellos la doctrina empleada fuera la mejor).

El Tribunal Constitucional español ha tenido oportunidad de pronunciarse sobre la prohibición de discriminación por razón de género en varias decenas de ocasiones. Ha considerado como discriminaciones directas, prohibidas por la Constitución, por ejemplo, medidas como las denominadas «cláusulas de celibato», es decir, las normas que suspendían el contrato de trabajo para el personal femenino al contraer matrimonio (se referían a Telefónica: STC 7/1983 y posteriores), o las numerosas discriminaciones por razón de embarazo [el Tribunal mantiene en este punto una tendencia inequívocamente garantista, pues ha extendido la protección de la trabajadora embarazada no sólo a los despidos (por todas: STC 136/1996), sino incluso, al período de prueba —STC 166/1988—, a la no renovación del contrato de trabajo — STC 173/1994_, a las funcionarias interinas —STC 20/2001—, a las discriminaciones ocultas — por ejemplo, en la Sentencia 98/2003 el Tribunal estimó el amparo presentado por una trabajadora que ocupaba la jefatura de la secretaría de un consejero regional pues fue cesada formalmente por «errores e incumplimientos en el desempeño de sus funciones» pero, en realidad, por haberse quedado embarazada - ] o incluso en el caso de no dar opción a la trabajadora a mejorar sus condiciones laborales por encontrarse de baja por embarazo de riesgo (STC 3/2017).

En casos de discriminación, se invierte la carga de la prueba, esto es, corresponde a la trabajadora acreditar la existencia de indicios de que ha sufrido la discriminación, pero es el empleador quien debe probar la existencia de causas suficientes, reales y serias para calificar de razonable su decisión y destruir así la sospecha de lesión constitucional generada por los indicios. En la STC 162/2016 el Tribunal otorga el amparo a una magistrada a quien se niega los derechos económicos y profesionales inherentes al cargo por no haber podido tomar posesión de la plaza al disponer de licencia por embarazo; y en la STC 2/2017 se dispensa el amparo a una trabajadora a la que, con posterioridad a su embarazo y maternidad, se le impide ejercer su derecho preferente de modificación de las condiciones laborales reconocido por convenio.

En el capítulo de las discriminaciones directas, hay que llamar la atención sobre algunas Sentencias de gran valor simbólico e histórico: la que considera, por ejemplo, que la inadmisión por el Ministerio de Defensa de una mujer a las pruebas para el ingreso en la Academia General del Aire es una medida contraria al artículo 14 CE (STC 216/1991), y la que declara inconstitucional el artículo 1 del Decreto de 26 de julio de 1957 que prohibía el trabajo de la mujer en el interior de las minas (STC 229/1992).

La Sentencia del Tribunal Constitucional 224/1999 tiene el mérito de haber configurado por primera vez el acoso sexual como una forma de discriminación sexual (así como una violación del derecho a la intimidad del artículo 18.1 CE). Para que pueda apreciarse un acoso sexual el Tribunal exige «una conducta de tal talante por medio de un comportamiento físico o verbal manifestado en actos, 
gestos o palabras», comportamiento «que se perciba como indeseado e indeseable por su víctima» y que «sea grave, capaz de crear un clima radicalmente odioso e ingrato».

Un caso de discriminación directa resuelto de manera discutible es el de la Sentencia 126/1997, que va a declarar no contraria al artículo 14 CE una no negada discriminación directa, la regla de la preferencia del varón sobre la mujer en el orden regular de las transmisiones hereditarias de los títulos nobiliarios (contenida en la Partida 2.15.2, en vigor). Más exactamente, el TC estima que no es de aplicación en este caso el típico examen judicial estricto sobre cualquier posible discriminación sexual, pues «admitida la constitucionalidad de los títulos nobiliarios por su naturaleza meramente honorífica y la finalidad de mantener vivo el recuerdo histórico al que deben su otorgamiento, no cabe entender que un determinado elemento de dicha institución —el régimen de su transmisión mortis causa - haya de apartarse de las determinaciones establecidas en la Real carta de concesión». Los votos particulares de los Magistrados C. Viver, T. Vives y P. Cruz sostuvieron, sin embargo, que el orden regular de sucesión de los títulos nobiliarios, al que es aplicable la Constitución y su artículo 14, es una discriminación frontal por razón de sexo pues dicho orden se establece en una norma jurídica (y no en «una simple regla de comportamiento establecida por determinados grupos sociales en virtud de sus particulares convenciones») y los actos de concesión, rehabilitación y transmisión mortis causa de los títulos nobiliarios no son fruto tampoco de relaciones inter privatos, sino ejercicio de facultades públicas del Monarca [artículo 62.f)], en el que intervienen diversos órganos estatales (desde el Consejo de Estado hasta los órganos judiciales, pasando por el refrendo del Ministro de Justicia), «y todo este proceso está regido por normas cuyo contenido no se limita a reconocer un ámbito de autonomía de la voluntad o privada, sino que establecen auténticas reglas de iuscogens, plenamente integradas, y esto es aquí lo más relevante, en el ordenamiento jurídico vigente en la actualidad en España». El problema ha sido resuelto legislativamente más tarde con la Ley $33 / 2006$, que ha suprimido la regla de la preferencia de los varones en orden a heredar los títulos nobiliarios.

El Tribunal Constitucional incorporó en nuestro ordenamiento el concepto de discriminación indirecta en la STC 145/1991 y la ha utilizado en varias ocasiones posteriores. Por ejemplo, en la STC 58/1994, consideró que era discriminatorio que las empleadas de las secciones de envasado y expedición de una empresa, a pesar de ostentar categorías profesionales superiores o equivalentes a las de sus compañeros de las mismas secciones, percibieran una retribución mensual sensiblemente inferior. El Tribunal apreció una discriminación prohibida pues el empleador no justificó suficientemente la diferencia de trabajos entre hombres y mujeres en orden a concederles una retribución distinta y, además, el único criterio de diferencia que mencionó fue el del «mayor esfuerzo físico» de los varones, criterio que, formulado aisladamente, es sexista. Es interesante también la STC de 22 de marzo de 1999, que concedió el amparo a un sindicato 
porque el Tribunal Superior de Justicia que conocía de un proceso en el que se discutía la política de contratación casi exclusivamente en favor de varones de una empresa (Fasa-Renault), se negó a incorporar al proceso ciertos documentos que hubieran acreditado indicios suficientes de discriminación (por ejemplo, en un año Fasa contrató 120 varones y ninguna mujer) y hubieran permitido, en ese caso invertir la carga de la prueba, correspondiendo a la empresa probar que su política de contratación era objetiva y ajena a toda intención discriminatoria. A partir de esta decisión, la Sentencia del Tribunal Supremo (Sala de lo Social) de 4 de mayo de 2000, estimó la pretensión del sindicato declarando que la empresa habría incurrido en una conducta discriminatoria indirecta en su política de contratación ya que la empresa no aportó una justificación objetiva y razonable de por qué exigía el título de Formación Profesional II para realizar unas funciones que no requerían tan formación, siendo «desproporcionado y perjudicial para el colectivo femenino que por razones socio-económicas no suele poseer tan título». Por su similitud, esta Sentencia bien podría calificarse como la Sentencia «Griggs» española.

La jurisprudencia del Tribunal Constitucional ha sido abundante también por lo que se refiere a la igualdad de oportunidades. De hecho, incorpora el concepto de «acción positiva» en la STC 128/1987. El actor, un varón que no obtendrá éxito finalmente en su pretensión, recurre en amparo por entender que era discriminatorio el distinto régimen de prestaciones en concepto de guardería otorgado por su empleador, el INSALUD: mientras que todas las trabajadoras con hijos menores de seis años, e independientemente de su estado civil, tenían derecho a percibir una prestación por guardería, este derecho se atribuía únicamente a los trabajadores varones con hijos menores de seis años que fueran viudos. El test de la medida paternalista/compensadora, aplicado al caso, lleva al Tribunal a considerar conforme a Constitución el plus de guardería concedido sólo a las trabajadoras (y a los trabajadores viudos). Otra medida de acción positiva reconocida por el Tribunal ha sido el permiso de lactancia concedido sólo a las trabajadoras (STC 109/1993 — aunque en la actualidad se concede a los dos padres). Y, entre las medidas que el Tribunal declara paternalistas o falsamente protectoras, se hallan la norma de un convenio colectivo que otorgaba a las auxiliares de vuelo mayores de treinta y cinco años y menores de cuarenta (pero no a sus compañeros varones) el derecho de retiro anticipado (STC 207/1987); el convenio colectivo de Telefónica que concedía un plus de transporte nocturno sólo a sus trabajadoras (STC 28/1992); la norma pre-constitucional que otorgaba a ciertas trabajadoras el derecho a una indemnización por ruptura del contrato de trabajo a consecuencia de su matrimonio (STC 317/1994).

Dentro de la jurisprudencia, resultan de interés, por último, dos tipos de decisiones, una relativa a las listas electorales equilibradas en cuanto al género, y la otra atinente a la violencia de género doméstica. La STC 12/2008 versa sobre la composición equilibrada de mujeres y hombres en listas electorales. El Tribunal se enfrenta a un caso claro de igualdad de oportunidades (aunque 
formalmente, como veremos, la medida controvertida era exquisitamente neutral en cuanto al sexo), pero ya no se apoyará en la doctrina compensatoria de la Sentencia 128/1987, sino directamente en el artículo 9.2 CE (que ordena a los poderes públicos promover la igualdad real y efectiva). Declarada la conformidad de la norma impugnada con el derecho de igualdad, el Tribunal examina otros aspectos problemáticos, concluyendo que la limitación de presentación de candidaturas por parte de los partidos que entraña la norma es válida, que tampoco afecta a la libertad de asociación de los partidos para organizarse como deseen, ni su libertad ideológica o de expresión, ni tampoco se fragmenta el cuerpo electoral.

La doctrina de la Sentencia 12/2008 se viene a reproducir más tarde en la Sentencia 13/2009, de 19 de enero, aunque en este último caso hay interesantes matices diferenciales. El primero es que no sólo se refiere al sistema electoral, sino también a la función pública y el segundo es que, en materia electoral, la disposición impugnada fijaba una representación mínima en las listas de candidatos electorales de mujeres del $50 \%$ y de hombres del $40 \%$.

Es remarcable también la STC 59/2008 respecto de la redacción que el artículo 37 de la Ley orgánica de violencia ha dado al artículo 153.1 del Código Penal, fallando que la norma penal que castiga más a los hombres cuando maltraten a sus mujeres o ex-mujeres que a las mujeres cuando maltraten a sus parejas varones es conforme con la Constitución. Concretamente, la pena para el varón que, de cualquier modo, cause menoscabo psíquico o lesión (que no fueran constitutivos de delitos) o golpeare o maltratare (sin causar lesión) a la esposa o pareja con la que conviva será de seis meses a un año de prisión, mientras que si la víctima es el hombre y la ofensora la mujer, la pena será de tres meses a un año. La diferencia está, pues, en esos tres meses del límite mínimo de la prisión. La duda de adecuación a la Constitución de esta norma (artículo 153.1 Código Penal) se centraba en si ese diferente trato penal lesionaba o no el principio de igualdad constitucional entre mujeres y hombres. ¿Cómo argumentó el Tribunal?: (1) El legislador penal tiene una amplia libertad para determinar delitos y penas y que el Tribunal Constitucional debe contenerse a la hora de valorar la política criminal establecida por las Cortes, ciñéndose sólo a los notorios excesos del marco constitucional. (2) La diferencia de trato establecida por la norma penal es razonable, por tres motivos: (a) Persigue una finalidad legítima, prevenir las agresiones que en el ámbito de las relaciones de pareja se producen como manifestación del dominio del hombre sobre la mujer. (b) Es una norma adecuada a esa finalidad legítima, por dos motivos: primero, la frecuencia de los delitos de violencia en que la víctima es la mujer, lo que demuestra la mayor necesidad objetiva de protección de ésta; segundo, el mayor desvalor (o gravedad) de este tipo de conductas porque «manifiestan la discriminación y la relación de poder de los hombres sobre las mujeres». Hay aquí una violencia peculiar, que merece un mayor reproche, ya que atenta contra la dignidad, seguridad y libertad de las víctimas de un modo más intenso. (c) Es una norma proporcionada o medida porque la diferencia 
de trato es escasa (sólo esos tres meses del límite mínimo de la prisión a imponer). En mi opinión, la violencia de género (cuando lo sea de verdad) es un delito pluriofensivo porque lesiona varios bienes jurídicos (además de la integridad de la víctima, también la igualdad) y, por ello, puede merecer más pena. Desde el punto de vista práctico, el caso planteado carecía por completo de importancia; lo realmente decisivo es la transformación de faltas en delitos y el endurecimiento de estos.

Una última Sentencia de gran interés jurídico y político es la STC 37/2018, que se pronuncia sobre la validez constitucional de «la enseñanza diferenciada por sexos» (art. 84.3 LOMCE) concluyendo que no supone una discriminación de género. El argumento principal es de carácter internacional. Utilizando el canon interpretativo del art. 10.2 CE y la propia remisión que el artículo de la LOMCE impugnado hace al art. 2 de la Convención de la UNESCO de 14 de diciembre de 1960 relativa a la lucha contra las discriminaciones en la esfera de la enseñanza, ratificada por España en 1969, el Tribunal sostiene que la separación de alumnos por género es válida siempre que dicha separación no produzca un trato menos favorable para nadie. Ciertamente, la Sentencia recuerda, desde el punto de vista potencialmente contrario, que otro texto internacional también ratificado por España, la Convención de Naciones Unidas sobre toda forma de discriminación hacia la mujer, de 18 de diciembre de 1979, compromete a los Estados parte al «estímulo de la educación mixta y de otros tipos de educación para lograr el objetivo de eliminar todo concepto estereotipado de los papeles masculino y femenino en todos los niveles y formas de enseñanza». El Tribunal constata que en España el modelo mixto casi se ha alcanzado, pero que la norma mencionada no obliga a los Estados a que su sistema sea completamente mixto (el precepto se refiere también a «otros tipos de educación»), sino a que se elimine todo tipo de educación machista, resultando que el art. 84.3 LOMCE impugnado obliga a los centros que quieran diferenciar por género a exponer en su proyecto educativo las medidas académicas que piensan desarrollar para favorecer la igualdad, dando así cumplimiento a lo establecido por la Convención. Un segundo argumento que emplea el Tribunal es el comparativo: la educación diferenciada por género se permite también en países como Reino Unido, Francia, Alemania, Bélgica o Estados Unidos.

El Tribunal, examinando si la educación diferenciada constituye una discriminación de género (art. $14 \mathrm{CE}$ ), afirma que, en efecto, se produce una diferencia jurídica de trato en cuanto al acceso al centro escolar, pero estaría justificada como «modelo o método pedagógico» en la medida en que «determinadas concepciones» consideran que «resulta más eficaz un modelo de educación de esta naturaleza que otros». Además, es un modelo de voluntaria adopción por los centros y de libre elección por los padres y, en su caso, por los alumnos. Como tal, forma parte del ideario educativo del centro, que es una facultad de la libertad de creación de centros docentes (art. 27.6 CE), aún dentro de los límites del art. 27.2 CE. 
Un aspecto no precisamente menor de esta Sentencia es el relativo a si, incluso admitida la constitucionalidad de la educación diferenciada, las administraciones educativas autonómicas están obligadas o no a financiar o concertar este tipo de colegios en igualdad de condiciones que los colegios mixtos. El Tribunal considera que sólo si la educación diferenciada fuera declarada inconstitucional habría que negarse a concertar; como ocurre justo lo contrario, los colegios que separan por género deben poder ser concertados en idénticas condiciones que el resto.

Obviamente, esta Sentencia es bastante controvertida. De hecho, hasta cuatro magistrados emiten opiniones discrepantes (y otra, concurrente). Algunos de sus argumentos son de este tenor: la educación segregada por género (los magistrados creen que la separación no es simple «diferenciación», sino una auténtica «segregación», con el matiz negativo que esto conlleva) niega el papel de la escuela como espacio por excelencia de socialización y convivencia en la igualdad y contribuye a perpetuar los estereotipos sexistas; cualquier diferenciación jurídica por género exige una justificación muy rigurosa, que la mayoría del Tribunal no ha realizado; la equivalencia formativa entre escuelas segregadas y mixtas no es tal (el principio «separados pero iguales» es tan formal como falso); la mayoría niega razones ideológicas a la escuela segregada, pero las tiene; no se han demostrado las presuntas ventajas pedagógicas de la separación; la segregación de niños y niñas no tiene en cuenta a los transexuales e intersexuales.

A mi juicio, la educación que separa a chicos y chicas no es segregadora en sentido estricto porque la segregación requiere separación fáctica de dos grupos de escolares y también que los resultados de uno de ellos sean manifiestamente peores que los del otro. Esto ocurre en la práctica con la segregación étnica en España: con los pobres resultados que obtienen los escolares gitanos en centros con alta densidad de minorías étnicas en comparación con quienes no lo son. Aquí sí hay segregación. Como la hubo hace años en relación con los escolares con discapacidad. La separación de chicos y chicas no produce, sin embargo, diferencia de resultados (puede ser, incluso, que los resultados de las mujeres fueran mejores). Pero, por otro lado, esa separación contradice el concepto de «educación inclusiva», esto es, de un modelo de educación ideal que reúne en el mismo aula tendencialmente a todos los alumnos de edades semejantes sin tener en cuenta género, grado de inteligencia, nacionalidad, tipo y grado de discapacidad, etc. Por ello, en todo caso, debiera admitirse con límites: nunca en el sistema público, por ejemplo. O en el sistema privado en una localidad donde sólo se dispusiera de esta oferta. Y de ahí también que sea jurídicamente razonable excluirla de la posibilidad de concierto, aunque el Tribunal haya sentado que también lo es incluirla.

\section{OCTAVIO SALAZAR BENÍTEZ}

Sin duda, el Tribunal Constitucional ha desempeñado un importante papel en la consolidación progresiva no solo de un Derecho antidiscriminatorio desde 
el punto de vista del sexo, sino también desde la consolidación de un derecho que, de manera expresa, no está en la Constitución: la igualdad efectiva de mujeres y hombres. Aunque en un primer momento, y como bien se ha señalado por los y las especialistas en el principio de igualdad, la jurisprudencia constitucional tuvo un carácter que podríamos calificar más de paternalista que de garantista. De hecho, en un primer momento el TC avaló la inaplicación de normas previas a la Constitución que beneficiaban a las mujeres —en algún caso ante recursos planteados por varones-, pero sin entrar a valorar las condiciones materiales en que se hallaban unas y otros. Es decir, se limitó a aplicar la lógica formal de la prohibición de discriminación del art. 14 CE.

Aunque posteriormente el TC fue incorporando una interpretación conjunta de los arts. 14 y $9.2 \mathrm{CE}$, siguiendo la jurisprudencia del TEDH, detectamos en él una evidente primacía del derecho a la igualdad formal. Una dimensión que lógicamente es más que suficiente para los hombres ya que nosotros partimos de una posición de ventaja, la cual se proyecta desde la misma titularidad del poder constituyente. Y, por supuesto, el TC no ha incorporado la perspectiva de género como criterio interpretativo ni ha logrado de manera evidente incorporar los mandatos que al respecto establece el Derecho Comunitario y, a nivel interno, la Ley Orgánica 3/2007. Algo que no ha sido ajeno, me temo, a que el Tribunal haya sido y sea todavía hoy un órgano casi monopolizado por magistrados varones.

Salvo en contadas excepciones, como podrían ser las sentencias 12/2008 y $59 / 2008$, la jurisprudencia constitucional es excesivamente deudora de una concepción formalista, y falsamente universalista, de la igualdad. Frente a ella, recordemos que, en la primera de las sentencias citadas, el TC incide en reconocer la igualdad sustancial como un «elemento definidor de la noción de ciudadanía» (STC 12/2008, FJ 5), o cómo en la segunda se justifica el diferente trato penal entre mujeres y hombres a partir de la diferente posición social de unas y otros, es decir, en la pervivencia del sistema sexo/género. Por otra parte, también resulta llamativo que solo en escasas ocasiones el TC haya recurrido a la Convención sobre la eliminación de todas las formas de discriminación contra la mujer (CEDAW), ratificada por nuestro país en 1983, como parámetro interpretativo.

De esta manera, sus contribuciones no han sido lo decisivas que cabría esperar porque no ha logrado incorporar en sus fundamentos el carácter sistémico de la discriminación por razón de género. Una ausencia que resulta más flagrante cuando pensamos en como el TC se ha enfrentado a cuestiones tan esenciales para las mujeres como la discriminación laboral, la maternidad, el aborto o la violencia. De esta manera, podríamos concluir que el TC se ha limitado a reaccionar ante las discriminaciones más que promover, a través de sus argumentaciones y fallos, una remoción de lo que M. ${ }^{a}$ Ángeles Barrère denomina «subordiscriminación» de las mujeres. En este sentido, creo que nuestro Tribunal Constitucional ha reproducido una cultura jurídica que continúa siendo androcéntrica y legitimadora de un orden patriarcal, algo a lo que sin duda ha contribuido el flagrante 
desequilibrio que desde el punto de vista del género ha tenido siempre su composición. Baste con señalar como no ha logrado hacer un uso eficaz y depurado de la discriminación indirecta, o cómo se ha enfrentado a las discriminaciones que las mujeres sufren por razón de la maternidad. En este sentido, podríamos citar la reciente y discutible resolución del amparo solicitado conjuntamente por un padre y por la PPiiNa (Plataforma por permisos iguales e intransferibles de nacimiento y adopción). En la sentencia de 17 de octubre de 2018, el TC insiste en que la función del permiso de maternidad es proteger la salud de la madre, por lo que no entiende que sea discriminatorio que el de paternidad tenga una duración menor. Es llamativo cómo la sentencia ni siquiera alude a la discriminación indirecta que la maternidad provoca en el acceso y permanencia de las mujeres en el mercado laboral, ni como los derechos/deberes de responsabilidad son hoy por hoy un factor esencial para lograr la igualdad efectiva que exige el mandato del art. 9.2 CE. Pierde pues el TC la ocasión de haber analizado el impacto negativo que tienen en las mujeres las medidas garantistas de la maternidad, y los paralelos privilegios de los que disfrutamos los hombres. Es decir, esta sentencia es un magnífico ejemplo de cómo el TC no tiene presente la dimensión relacional que implica el género ni las estructuras sociales y económicas que continúan dividiendo la ciudadanía en dos esferas (la pública masculina y la privada femenina). Es curioso cómo la sentencia no alude en ningún momento a los criterios interpretativos que marca la $\mathrm{LO} 3 / 2007$, ni por supuesto incorpora en sus razonamientos las herramientas que el feminismo jurídico lleva décadas aportando para hacer eficaz, también desde el punto de vista de la interpretación y la aplicación del Derecho, el mandato del art. 9.2 CE. Tal y como subraya el voto particular de la magistrada María Luisa Balaguer: «Hoy ya no se trata de lamentar que la mujer concentre la mayor parte de cargas derivadas del cuidado de la familia, y particularmente del cuidado de los hijos, porque sigue haciéndolo a pesar de los avances innegables. Se trata de analizar por qué las medidas desarrolladas para compensar esa realidad social, destinadas fundamentalmente a las mujeres, no logran superar como debieran esa realidad y no aseguran la igualdad real de las mujeres en el acceso al mundo laboral y su promoción dentro del mismo. Se trata de examinar por qué esas medidas no logran atajar el problema del desigual reparto de los desincentivos entre los hombres y las mujeres».

Pareciera pues que el TC no tuviera presentes, y de hecho ni siquiera son citados en esta sentencia, los artículos 1, 2, 3, 4 o 15 de la LO 3/2007. En general, han sido pocas las ocasiones en que el TC ha usado los preceptos de la LO 3/2007 como criterio de interpretación de la constitucionalidad de las normas. Podemos citar como excepción a esta pauta la STC 13/2009, de 19 de enero, que resolvió el recurso de inconstitucionalidad contra la Ley Vasca 4/2005, de 18 de febrero, para la igualdad de mujeres y hombres en el País Vasco, y la STC 159/2016, de 22 de septiembre, en la que resuelve el recurso de inconstitucionalidad planteado por el Gobierno contra la Ley catalana 17/2005, de igualdad efectiva de mujeres y hombres. Un reciente ejemplo llamativo de ausencia de la 
perspectiva de género es la sentencia 31/2018, de 10 de abril de 2018, en la que se avaló la constitucionalidad de la previsión de la LOMCE según la cual es posible establecer conciertos educativos con centros que impartan una enseñanza segregada por razón de sexo. La mayoría del Tribunal no tuvo presente que, como bien señaló la magistrada M. ${ }^{a}$ Luisa Balaguer en su voto particular, «la educación diferenciada tiende a consolidar estereotipos basados en la diferenciación de los sexos por roles, por capacidades, y por posiciones en la sociedad, porque son esos mismos estereotipos, sin base científica, los que dan sustento a la teoría pedagógica segregacionista. No es este un modelo capaz de superar los estereotipos, y las dificultades de igualación entre hombres y mujeres, que demanda el artículo 9.2 $\mathrm{CE}$, porque se basa precisamente en dichos estereotipos. El equilibrio entre la formación de la ciudadanía, y la educación del alumnado, quiebra con esta medida, que por ello no puede considerarse proporcional a la hora de asegurar la garantía del derecho a la igualdad (art. 14 CE) y a la educación, con el objeto de que a ella asocia el artículo 27.2 CE.»

La ausencia del género como clave interpretativa ha impedido que el TC ponga las bases para asumir la paridad como un principio esencial de una democracia en la que las dos mitades de la ciudadanía, la masculina y la femenina, han de disfrutar de los mismos derechos y oportunidades. Un objetivo que difícilmente se logrará mientras que se continúen usando herramientas propias de la igualdad formal (liberal) y en tanto no se parta, como bien han explicado juristas como M. a Ángeles Barrère, de la consideración de la discriminación de las mujeres como el resultado de un sistema de poder que atraviesa todas las estructuras sociales. Lo cual obliga a revisar buena parte de los conceptos jurídicos heredados, tarea que el TC se ha resistido a hacer en estas décadas, lo cual, sin duda, ha tenido una repercusión negativa en cuanto que ha contribuido a mantener una cultura jurídica que hace que la normativa en materia de igualdad de género continúe encorsetada bajos las limitaciones propias del soft law.

7. Transcurridos ya unos años, ¿Cómo cabe valor la actividad del legislador en esta materia, especialmente a través de las leyes de igualdad y contra la violencia de género?

\section{MARIA LUISA BALAGUER CALLEJÓN}

Desde la década de los noventa, un importante sector de la doctrina constitucionalista se plantea la necesidad de legislar en materia de género, como una forma imprescindible de reducir las diferencias entre mujeres y hombres en algunos aspectos de la representación política, cuyos niveles de participación no alcanzaban el diez por ciento. Esta posición coincide con la de los demás países de nuestro entorno, que, con porcentajes parecidos, en algunos casos, como 
en Francia del siete por ciento, habían planteado el tema de las cuotas electorales como forma de desigualdad compensatoria, para reducir la diferencia entre la representación política de mujeres y hombres. En el sistema constitucional francés, el Conseil consideró necesaria una reforma constitucional que se llevó a cabo, y tras la que se aprobó una ley que establecía un porcentaje de mujeres mínimo del 33 por ciento, en las listas electorales.

En España, el debate se centró en torno a si las limitaciones del derecho de representación política, que afectaban a los hombres, podían considerarse contrarias al art. $23 \mathrm{CE}$, e igualmente a la cuestión competencial, al publicarse la primera ley autonómica paritaria en materia electoral, que fue recurrida, igual que la segunda, ante el Tribunal Constitucional. Algunas CC.AA. llevaron a cabo igualmente estas medidas, como el País Vasco y Andalucía con porcentajes superiores, y en una relación que se llamó «lista cremallera», como esta última Comunidad Autónoma, que exigía que el orden de la lista mantuviera la alternancia de género.

En el Estado esta reforma de la LO 5/1985, de Régimen Electoral General, se llevó a cabo como es sabido en la LO 3/2007, de 22 de marzo, para la Igualdad entre Mujeres y Hombres, y fue objeto de un recurso de inconstitucionalidad resuelto en la STC 12/2008, que consideró constitucional esta limitación del art. $23 \mathrm{CE}$, igual que las Sentencias que resolvieron sobre las dos últimas leyes autonómicas. El recurso de inconstitucionalidad de las dos primeras leyes autonómicas, fue desistido por el Gobierno de la Nación.

Otra exigencia legislativa muy importante del debate de los años noventa, en relación con la igualdad de género, la constituyó la violencia de género, de la que se tomó conciencia a través de los medios de comunicación, marcándose un punto de inflexión tras el asesinato de una mujer quemada con gasolina por su marido, después de haber vuelto de un programa de televisión donde narraba los malos tratos de que había sido objeto en su matrimonio. El consenso social aquí fue mayor, y se trasladó al Parlamento, que aprobó la LO 1/2004, de 28 de diciembre, sin ningún voto en contra. Mantuvo sin embargo dos disensiones importantes: la primera respecto de la denominación de la palabra «género», en referencia a las mujeres, y la segunda desde el punto de vista del agravamiento de las penas en la modificación del art. 153.1 del Código Penal, en función el sujeto activo del delito.

Tanto la terminología como el tipo penal fueron analizados por el TC en las cuestiones de inconstitucionalidad planteadas por la jurisdicción ordinaria, e inadmitidas, por entender que la agravación del tipo quedaba justificada porque era justamente la pertenencia al género, (como construcción justificada desde el punto de vista social del sexo femenino), lo que determinada en la estructura patriarcal de la sociedad, una posición dominante y desencadenante del delito.

Finalmente, la LO 3/2007, de 22 de marzo, como ley de igualdad de género, tuvo un especifico contenido feminista, y reguló instituciones concretas respecto de la igualdad de género, que trasponían importantes categorías de la legislación 
europea: las acciones positivas de igualdad, la perspectiva de género, la inversión de la carga de la prueba en los procesos en que se invocara la discriminación de la mujer, el acoso sexual o el acoso en el trabajo, y un número importante de medidas de igualdad en los diferentes ámbitos de la vida social y privada: educación, trabajo, medios de comunicación, participación política y otros, de manera que debería haber sido un importante medio de avanzar en la igualdad de género. Sin embargo, salvo situaciones como la de la representación política, cuya normatividad era directa, en una buena parte de su regulación la ley no está siendo efectiva. En algunos casos, como en la publicidad, ha sido prácticamente inaplicada, por no decir en su totalidad, pues existe algún caso aislado de estimación de publicidad ilícita, pero no ha tenido la menor incidencia en el ámbito publicitario. $\mathrm{O}$ las normas que hacen referencia a la presencia de las mujeres en los Consejos de Administración de las empresas, que son abiertamente ignoradas.

La respuesta del legislador, contestando directamente a la pregunta, ha sido muy positiva y muy activa desde la década de los noventa, porque puede decirse que en todos los órdenes jurisdiccionales se ha legislado en materia de género, pero estas normas no están teniendo la efectividad que el derecho a la igualad reclama. Las razones son variadas porque se trata de leyes extensas, con múltiples operadores jurídicos y un escenario muy amplio, pero en general, pueden detectarse varias causas que impiden su efectividad. La primera es la posición de sujeto débil que la mujer ocupa en la sociedad, y que le impide en muchas ocasiones acceder a los derechos que la ley reconoce, por no tener acceso al asesoramiento, a la posibilidad de costear la defensa jurídica de sus derechos, e incluso a su falta de conciencia de su desigualdad. Las normas jurídicas requieren para su efectividad de algo más que su existencia, además han de ser interpretadas y aplicadas, y es en esta fase del derecho en la que muchos derechos se pierden y no muestran su efectividad. Esto ocurre en la ley de igualdad, cuya aplicación es muy reducida en la práctica porque exige una interpretación con perspectiva de género, de la que la mayoría de los operadores jurídicos carece. La consideración androcéntrica del derecho es el paradigma sobre el que se construye toda actividad interpretativa de las normas jurídicas, de manera que cuando se pretende la aplicación de estas normas con unos criterios hermenéuticos asentados en estos valores, el resultado no puede ser igualitario, siquiera sea por la clara idea generalmente aceptada de que la neutralidad favorece necesariamente el statu quo.

\section{PALOMA BIGLINO CAMPOS}

Antes señalaba que la situación de las mujeres en España es mejor que la de otros países de nuestro entorno. Conviene ahora señalar que, en gran medida, es gracias a la actividad del legislador, tanto estatal como de las Comunidades Autónomas. Ahora bien, esta acción, con ser necesaria, todavía es insuficiente ya que queda mucho por hacer. 
En primer lugar, considero que es precisa mayor intervención para remover discriminaciones en los sectores económicos privados. Hay ejemplos que demuestran que este tipo de medidas no son perturbadoras de la economía de mercado. Según los datos de un reciente estudio elaborado por Fedea ${ }^{6}$, países como Noruega, Francia, Bélgica, Alemania, Italia e Islandia ya aplican políticas de cuotas obligatorias para las empresas que cotizan en bolsa y para las públicas. Pero, además, y en segundo lugar, creo que debería establecerse mayor control sobre el cumplimiento de las normas que tienden a garantizar la igualdad en cualquier ámbito. También hay ejemplos de ello: en Islandia, las empresas de más de 25 trabajadores tienen que realizar auditorías externas para demostrar que tanto salarios, como complementos salariales, sean idénticos, bajo amenaza de cuantiosas multas.

Es cierto que las leyes de igualdad dictadas por el Estado y por las Comunidades Autónomas y la legislación sobre violencia de género han desempeñado un papel muy positivo, no sólo en nuestro ordenamiento, sino también en la mentalidad social dominante, porque demostraron un compromiso activo de los poderes públicos con la causa de las mujeres. Ahora bien, muchos de sus preceptos contienen más principios y valores que reglas, por lo que siguen sin aplicarse o aplicándose de forma insatisfactoria. La apuesta de futuro no está, pues, sólo en extenderlas, sino en poner los medios para que resulten realmente efectivas. Sobre todo, en controlar su cumplimiento, extrayendo las consecuencias jurídicas debidas en caso de infracción.

\section{ÁNGELA FIGUERUELO BURRIEZA}

Tanto la Ley de Igualdad como la Ley Integral contra la Violencia de Género marcaron un hito en el primer gobierno del Sr. Rodríguez Zapatero y fueron un referente internacional a la hora de elaborar, en países de nuestro entorno democrático, normas que perseguían objetivos similares. La finalidad de las normas jurídicas consiste en dar respuestas a los problemas que se generan en el ámbito social. La lacra de la violencia de género y las históricas desigualdades entre mujeres y hombres eran los fines que se perseguían con la aprobación de dichas normas. En el año 2004 se aprobó la norma que pretende prevenir y erradicar la violencia de género y en el año 2007 la Ley Orgánica para la Igualdad efectiva de mujeres y hombres; ambas normas generaron amplias expectativas en todos los ámbitos de la sociedad pues se pensaba que con sus contenidos podíamos conseguir una sociedad más justa y solidaria donde se irían erradicando las desigualdades existentes.

Han pasado varios años ya desde que dichas normas están vigentes y, aunque las cosas han mejorado respecto al momento en que dichas normas fueron aprobadas, el

6 https://elpais.com/economia/2018/12/18/actualidad/1545157661_869304.html. 
balance no es tan positivo como fuera de desear. Es cierto que se ha culpado a la crisis globalizada de la escasez de medios públicos que hubieran podido desarrollar mejor los contenidos normativos.

Pero, en mi opinión, sin restar las «culpas» de la tan manida crisis, las sombras están en el ámbito de la sociedad y en el marco de la imprescindible educación en igualdad, tema al que no se le ha prestado la atención que se merece.

La lacra de la violencia de género persiste, aunque hayan disminuido el número de mujeres asesinadas a manos de sus parejas o exparejas; pero el drama se incrementa por los maltratadores que han generado una forma aún más brutal de hacer daño a las mujeres y consiste en asesinar a sus hijos. Se ha repetido hasta la saciedad que se elaboró la Ley Integral Contra la Violencia de Género pero que no se habilitaron los medios económicos y materiales para hacerla efectiva. A la falta de medios se une la carencia de formación en perspectiva de género de los operadores públicos y de todos los profesionales que tratan con las mujeres que sufren las violencias machistas. La gravedad de la situación obligó en 2017 a todas las fuerzas políticas del arco parlamentario a aprobar un Pacto de Estado Contra la Violencia de Género con una batería de más de 200 medidas que pretendían dar un tratamiento integral al tema intentando avanzar en la solución del problema. Se habló incluso de dotar al Pacto con una cuantía económica considerable a repartir en cinco años pero luego no se contemplaban esos medios en los Presupuestos Generales del Estado para que las distintas administraciones públicas pudieran desarrollar las medidas contenidas en dicho Pacto de Estado. Por fin un Decreto-Ley de agosto de 2018 ha despejado el tema para comenzar a trabajar en un asunto de tanto calado. Tampoco el Convenio de Estambul, aprobado en el Consejo de Europa y vigente desde 2014, ha conseguido aminorar esta lacra que es la prueba más evidente de la desigualdad que persiste entre mujeres y hombres, aunque algunos de sus contenidos se han visto reflejados en el precitado Pacto de Estado.

En resumen: el problema y su difícil solución no es achacable al contenido de las normas jurídicas vigentes; es un problema de los estereotipos sociales que persisten en una sociedad patriarcal y que únicamente podemos erradicar cuando de verdad eduquemos en igualdad desde la familia y en la escuela.

En lo referente a la LOI que nació con vocación de ser la ley código de la igualdad de mujeres y hombres el problema fundamental a la hora de valorar estos once largos de vigencia es que sus contenidos no se han implementado. Es una norma muy ambiciosa pero... está redactada en forma de recomendaciones y, estas no son de obligado cumplimiento. Únicamente aparecen redactados con carácter imperativo todas las normas — más o menos unas veinte- que hacen referencia al principio de presencia equilibrada; no sólo en las listas electorales sino también en los tribunales, comités de selección, órganos colegiados de la administración pública, etc. Pero también en este tema nos conformamos con un contenido de mínimos: es decir que las mujeres logren ocupar el $40 \%$ de la composición de dicho órgano cuando la norma en vigor admite una horquilla entre el $40 \%$ / $60 \%$ sin indicar qué sexo debe ocuparlo. 
Soy docente universitaria convencida de la imperiosa necesidad de educar en igualdad y de implantar en todos los niveles la formación y los estudios de género; este tema regulado «in extenso» en la LOI no ha merecido la debida atención y las autoridades competentes al tratar el asunto se suelen poner de perfil. Así las cosas, la sociedad avanza muy lentamente en la ansiada igualdad real de mujeres y hombres; derecho al que por naturaleza tenemos derecho y al que tantas trabas se ponen desde los distintos ámbitos donde el poder se escribe con letra mayúscula. Las mujeres tenemos todavía muchas dificultades para romper el «techo de cristal»; el ámbito del poder político, del poder económico, del ámbito cultural y científico... sigue estando en manos masculinas; aunque es cierto que hemos avanzado bastante en los últimos años aún queda lejos conseguir el tan anhelado reto de la efectiva igualdad de oportunidades.

Sin duda alguna el ámbito de las relaciones laborales es uno donde siguen persistiendo serias desigualdades. Buena prueba de ello son las dificultades de acceso al empleo, promoción y progreso en las relaciones laborales y la tremenda brecha salarial que aún persiste. Ello es debido en gran parte al peso de la maternidad y a la insuficiente implicación en las tareas domésticas y de crianza de los hijos por parte de los varones. Las políticas públicas existentes a día de hoy se han mostrado insuficientes. También el mundo del conocimiento se escribe en masculino: basta echar un vistazo a las Universidades y ver la escasez de Catedráticas, Rectoras, Doctoras Honoris Causa... En las Reales Academias también son muy pocas las mujeres que son miembros de las mismas. Son casi inapreciables las mujeres que han recibido un Premio Nobel, Príncipe de Asturias, Premio Cervantes... y eso que las Universidades son buena prueba de que las mujeres son mejores estudiantes que los hombres.

Hablar del mundo de la política nos llevaría excesivo espacio; pero España, afortunadamente, en estos momentos tiene un Gobierno donde las mujeres ocupan más del $60 \%$ del total de los ministerios. Profesiones también muy masculinizadas son las Fuerzas Y Cuerpos de Seguridad del Estado y la judicatura (profesión donde en la base hay más mujeres pero tienen aún muy difícil ascender a los puestos más altos de la carrera judicial). En el mundo empresarial las cosas avanzan muy lentamente a pesar del art. 75 de la LOI y de las recomendaciones de las Instituciones Europeas; y está demostrado que aquellas sociedades que prescinden del talento femenino, formado actualmente en igualdad de condiciones que los hombres, no avanzan por los cauces adecuados. Es cierto que sólo legislando con carácter obligatorio sobre el tema avanzaremos las mujeres en los puestos que nos corresponden en los Consejos de Administración de las empresas cotizadas de la eurozona.

Como reflexión final sólo me resta destacar la necesaria ayuda de los hombres igualitarios en esta empresa de la igualdad integradora de las diferencias y en la fuerza resilente de las mujeres para dejarles a nuestras hijas/os un mundo mejor donde ondee la bandera de la dignidad humana. 


\section{TERESA FREIXES SANJUAN}

Ya lo he indicado anteriormente. España ha sido pionera en estos ámbitos. La Ley de igualdad integral responde al criterio de transversalidad de la igualdad, que ha de estar presente en todos los ámbitos. Y la Ley contra la violencia de género ha sido tomada como modelo en muchos otros países por ser también una ley integral, que entra en los ámbitos educativos, penales, administrativos, etc.

Contamos con una buena legislación. Quizás a veces sea poco conocida técnicamente por los operadores jurídicos y de ahí que se generen problemas que podrían ser fácilmente evitados. El despliegue que la igualdad ha tenido en nuestro país es ingente, muy relevante jurídicamente, tanto en la legislación estatal como en la que han ido generando las Comunidades Autónomas.

Al ser, nuestro ordenamiento jurídico, un ordenamiento multinivel, en el que tienen que interpretarse en forma coherente, por el legislador y por los jueces, las normas producidas en cada uno de los niveles, internacional y europeo, estatal y autonómico, podemos concluir diciendo que contamos con un elevado nivel de protección, que tiene ser puesto en práctica por todos los operadores jurídicos, para dar respuesta a los problemas de discriminación que, desafortunadamente, todavía hoy se producen en la sociedad.

\section{ITZIAR GÓMEZ FERNÁNDEZ}

Como puse de manifiesto en la respuesta a la cuestión número 3, la actividad legislativa ha sido intensa, progresiva y la valoración final debe ser positiva. Pero también entiendo necesario continuar avanzando, especialmente en la línea de la reforma constitucional, para consolidar las conquistas legales alcanzadas y procurar, en la medida de lo posible, su irreversibilidad por la vía de su elevación a rango constitucional.

En materia de violencia de género, el problema es más complejo. No bastarán las reformas legales o constitucionales. No han bastado las preexistentes (y hoy vigentes) para acabar con el gravísimo problema. A mi juicio es fundamental, vital diría yo, trabajar en coeducación, siguiendo la estela de programas innovadores y centrados en el tema, como el programa SKOLAE, desarrollado en la Comunidad Foral de Navarra y pionero en España en este ámbito. Pero el juego de la libertad de los padres para elegir la educación moral que consideren oportuna para los hijos, pudiera actuar en contra de esta opción, sin duda rompedora, pero también imprescindible. Y aquí nos encontramos con la tensión, hasta hora irresoluble, entre los intereses de las empresas educativas (en el caso español, como sabemos, mayoritariamente la iglesia católica y sus entidades dependientes), los intereses de los padres, y el interés superior de conseguir una educación basada en valores constitucionalmente queridos, siendo eje de esos valores, en lo que ahora nos interesa, la igualdad. 
Sin más y mejor educación en igualdad, no seremos capaces, a mi juicio, de ir más lejos de donde ya estamos. Sin coeducación no lograremos cumplir el sueño de todas las que nos han precedido en la genealogía feminista, y que siempre han visto en la educación la llave del futuro y de la plena emancipación de las mujeres, y de las sociedades en su conjunto.

\section{FERNANDO REY MARTÍNEZ}

Antes sugerí que el enfoque de la legislación sobre conciliación debe variar radicalmente porque la vigente ha venido a consagrar más aún una carrera profesional «de serie $B$ » para muchas mujeres. El resto de la legislación está funcionando razonablemente bien, aunque los cambios esperables no han de venir tanto de las normas como de la realidad social. Sigue haciendo falta un cambio cultural en la comprensión de la igualdad porque los viejos estereotipos no terminan de morir. E incluso, de vez en cuando rebrotan aprovechando una cierta fatiga producida por el énfasis en las políticas de género. El feminismo teórico es múltiple, pero en España está a veces triunfando en las políticas sociales una versión paternalista del feminismo, la que califica, por ejemplo, a todas las mujeres que ejercen la prostitución como víctimas incapaces de salir de una situación que es objetivamente y siempre explotación y que, por tanto, preconiza suprimir los anuncios de prostitución en la prensa y prohibir, incluso penalmente, la prostitución, siguiendo el modelo sueco, pero sin tener en cuenta que esto no hace más que desplazar la publicidad a internet y confinar la prostitución a la clandestinidad, donde las mujeres en prostitución aún serían más vulnerables. Otro ejemplo: las mujeres víctimas de violencia de género, incluso leve, y su incapacidad para consentir ver en el futuro a su maltratador, que a veces es el padre de sus hijos; la violencia sufrida ha anulado también por completo su voluntad y el derecho viene a protegerlas de sí mismas. No soy especialista, pero el boyante «derecho penal de género» parece más un derecho penal del enemigo que viene a contradecir, más que a completar, los sólidos cimientos del derecho penal clásico.

Por no hablar de la discusión que también se está abriendo en el plano de las ideas sobre el feminismo dominante en la actualidad. Un libro reciente, influyente y provocador, en este sentido, es el de la filósofa francesa Bérénice Levet: Libérons-nous du féminisme!: nationfrançaise, galante et libertine, ne te reniepas! (Éditions de l'Observatoire, 2018). Esta autora denuncia el «feminismo llorica y regresivo» que coloca a las mujeres en pie de guerra contra los varones, criminaliza el deseo masculino, abomina de la galantería y el erotismo, sustituyendo el puritanismo religioso por uno nuevo, que crea un «nosotras» excluyente y es un feminismo «estúpido, infantil, enconado y arrogante», y que provoca un revisionismo pueril de la historia, la cultura y el arte. Según Levet, el feminismo dominante es «una máquina de infantilizar, atontar, vigilar y castigar» más que una herramienta de emancipación; es «el último relato de una izquierda» que no 
tiene ya nada más ilusionante en su chistera; y es un nuevo «orden moral» neopuritano. Detrás de la seducción, sostiene Levet, hay búsqueda de placer y no de dominación o humillación. El varón blanco occidental no es el enemigo a batir. Las mujeres no son por encima de todo las potenciales víctimas de depredadores masculinos, por más que exista violencia de género.

\section{OCTAVIO SALAZAR BENÍTEZ}

A pesar de todas las carencias y fragilidades señaladas en las respuestas previas, no cabe duda de que los instrumentos legislativos aprobados en nuestro país en los últimos 18 años han jugado un papel esencial en la transformación social y política de nuestro país. Podríamos considerar que, ante la ausencia de una apuesta constitucional por la igualdad de género, la suma de dos leyes complementarias, la LO 1/2004, de medidas de protección integral contra la violencia de género y la LO 3/2007, de igualdad efectiva de mujeres y hombres, podría entenderse como una especie de Código de Igualdad que ha sido decisivo en estos años en la superación de un orden patriarcal. Más allá de las medidas concretas previstas en ellas, ambas leyes, y muy singularmente, la LO 1/2004, han permitido asentar la visión de la discriminación sistémica de las mujeres y de cómo es la desigualdad de género la que provoca, entre otras terribles consecuencias, violencias que tienen como víctimas a las mujeres. Por otra parte, la LO 3/2007, tal y como han señalado Santiago García y Asunción Ventura en El derecho a la igualdad efectiva de mujeres y hombres. Una evaluación del primer decenio de la Ley Orgánica 3/2007 (Aranzadi, 2018), plantea «una nueva dogmática del derecho a la igualdad efectiva de mujeres y hombres». Esta ley, como ha señalado buena parte de la doctrina que desde una perspectiva iusfeminista la ha analizado, supone ir más allá de la discriminación por razón de sexo y garantizar como derecho la igualdad efectiva de mujeres y hombres.

Esta nueva dogmática es el resultado no solo de dicha norma estatal sino también de las autonómicas sobre la materia. No hay que olvidar la pionera apuesta legislativa de algunas Comunidades Autónomas que, recordemos, fueron las primeras en adoptar la estrategia dual consistente en sumar acciones positivas y mainstreaming de género. En muchos casos, como por ejemplo en Andalucía, los presupuestos de la democracia paritaria incluso han sido incorporados en el Estatuto e incluso se ha llevado a cabo una revisión reciente de leyes que habían quedado superadas por los cambios operados en los últimos años. Sirva como ejemplo la reciente Ley andaluza $7 / 2018$, de 30 de julio, por la que se modifica la Ley $13 / 2007$, de 26 de noviembre, de medidas de prevención y protección integral contra la violencia de género, en la que se introduce un concepto de violencia machista más próximo al Convenio del Consejo de Europa sobre prevención y lucha contra la violencia contra las mujeres y la violencia doméstica de 2011, conocido como Convenio de Estambul. 
Esta proliferación de leyes de igualdad, que sin duda han cumplido y cumplen un papel esencial en el cumplimiento de los mandatos que derivan de los art. 14 y $9.2 \mathrm{CE}$, plantea sin embargo un reverso del que debemos ser conscientes. De una parte, y de manera muy singular en esta materia, la descentralización territorial nos coloca frente a los problemas que en la práctica genera lo que se ha denominado «protección multinivel de los derechos». No cabe duda de que, en determinadas cuestiones como la violencia de género, algunos de los factores que contribuyen a su difícil erradicación, más allá del esencial que no es otro que la cultura machista dominante, están relacionados con una ausente o débil coordinación institucional, además de con la falta de recursos de los que deberían estar especialmente dotadas las Administraciones que de manera más inmediata tienen que enfrentarse con las necesidades de protección de las víctimas. Por lo tanto, también en esta materia, no podemos desconectar la evaluación de la efectividad de las políticas públicas de las carencias y debilidades que, por ejemplo, presenta el sistema de financiación autonómica, o de la escasez de recursos (y en algún caso hasta de competencias) de unas Administraciones locales que son las que de manera más inmediata y directa tienen que enfrentarse a los obstáculos que impiden en la vida cotidiana que las mujeres ejerzan su plena ciudadanía.

A todo lo anterior habría que añadir dos ideas que, sin ánimo de ser pesimista, me parece conveniente tener presentes para evitar equívocos. De entrada, sería de ilusos pensar que las leyes por sí solas pueden cambiar la realidad. Las leyes son, en un Estado de Derecho, un instrumento esencial para la transformación en términos de justicia social, pero no el único, o al menos, no desvinculado de un contexto en el que tienen que darse determinadas condiciones para que las normas sean plenamente efectivas. Las leyes de igualdad, y en general las acciones políticas que desde las instituciones puedan promoverse con tal de superar las discriminaciones de todo tipo, y mucho más las de género dado su carácter estructural, requieren de una cultura, entendida en un sentido amplio, en la que se progresivamente se hayan ido eliminando sesgos de género, estereotipos $\mathrm{y}$, en general, todos los imaginarios que durante siglos han alimentado una diferenciación jerárquica entre mujeres y hombres. En este sentido, me atrevería decir que en nuestro país la cultura, con relativa frecuencia, contribuye a deshacer lo que las leyes, cargadas de buenas intenciones, han previsto. No hay más que pensar en cómo desde los medios de comunicación, los relatos audiovisuales o los productos más consumidos en las redes sociales prorrogan actitudes y comportamientos que se hallan en las antípodas de los proyectos transformadores del legislador (y la legisladora). De ahí, insisto, la centralidad que debería tener la educación en la consolidación de una cultura que supere al fin los lastres machistas que continúan estando presentes en el siglo XXI. Y, de manera más específica, y como también he apuntado en las preguntas anteriores, es urgente superar una cultura jurídica que está más cerca del siglo XIX que de las realidades del 2019. Ello pasaría, entre otras cosas, por revisar la formación que siguen recibiendo los operadores jurídicos, por incorporar las teorías críticas del Derecho a la construcción de la Ciencia 
Jurídica y, por supuesto, por situar al feminismo jurídico en un lugar central en la elaboración, interpretación y aplicación de las normas. Bastaría con recordar cómo, frente a la unanimidad de los grupos políticos, fueron los jueces y las juezas quienes con más contundencia manifestaron su disconformidad con las medidas penales previstas en la LO 1/2004, siendo ésta la ley que ha sido objeto del mayor número de cuestiones de inconstitucionalidad. O cómo, todavía hoy, tras 40 años de democracia, tras más de diez años de vigencia de la Ley de Igualdad, sigue siendo noticia que un juez/una jueza o un Tribunal dicte sentencia teniendo en cuenta la perspectiva de género. De ahí que, junto a la necesaria reforma constitucional, y a la consolidación de unas políticas públicas de igualdad que deberían estar amparadas en el principio de no regresividad, sería urgente que la ciudadanía pudiera tener acceso a una Justicia sin sesgos de género.

$$
* * *
$$

TITLE: Academic survey about equality between men and women

ABSTRACT: In this academic survey a group of Constitutional Law Professors answer some questions about the equality between men and women: its constitutional recognition; the progress, achievements and obstacles in reaching this goal; the political and legal impulses received; the proposals for constitutional reform in this regard; and the work developed by the Constitutional Court and the legislator.

Resumen: En esta encuesta un grupo de profesores de Derecho Constitucional contesta un conjunto de preguntas sobre el principio de igualdad entre hombres y mujeres: su reconocimiento constitucional; los avances, logros y obstáculos en la consecución de este objetivo; los impulsos políticos y jurídicos recibidos; las propuestas de reforma constitucional al respecto; y la labor desarrollada por el Tribunal Constitucional y el legislador.

KEY WORDS: equality principle, equality between men and women, non discrimination.

Palabras Clave: principio de igualdad, igualdad entre hombres y mujeres, no discriminación.

FECHA DE RECEPCIÓN: 15.01.2019 FeCHA DE ACEPTACIÓN: 05.02.2019 
